Historic, Archive Document

Do not assume content reflects current scientific knowledge, policies, or practices. 


\section{ANNUAL CATALOG HIGH GRADE SEEDS FOR 1913}

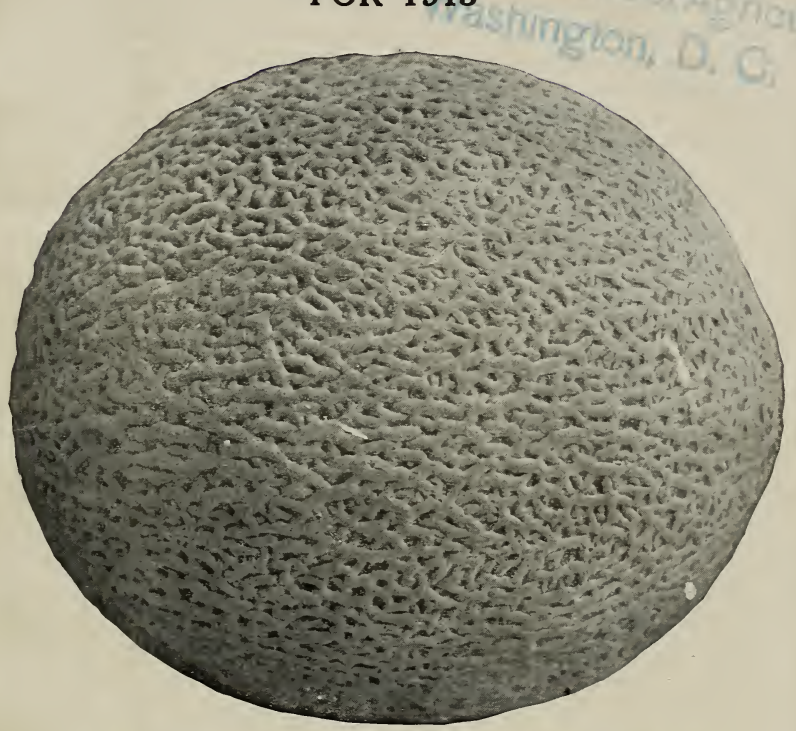

Burrell's Select Rust-Resistant Rocky Ford Cantaloupe If It's Only One-Make This the One

The finest varieties, grown by the most critical growers for those who want to plant of the best to be had. When there are better varieties or better selections produced I will offer them. I spare no pains or expense to secure the best.

\section{V. BURRELL SEED GROWER ROCKY FORD, COLO.}

Keep This Catalog to Order From Until 1914 Catalog Comes 


\section{GREETING:}

Last year I increased the number of catalogs which I sent out to two hundred thousand $(200,000)$ and received double the amount of orders from old customers I ever received before, and what also means much, I received three times as many orlers from new customers. Now I have increased the number of catalogs again and prepared for another increase. I have harvested the best and biggest crop I ever grew and have all my floors stacked to the ceilings with fine seeds. The tests run high this year and very often 95 to 100 per cent. All the seed I send out is carefully tested and intended for the most particular planters. See the list of a few of my customers on the back cover page. I could name thousands more, but this shows you that while some seedmen have a larger business (because they are so much older), no seedman in the world gets better orders from planters or supplies more successful planters than $I$.

If you plant only a few seeds or if you plant hundreds of acres, plant Burrell's Best Seeds and you are started right.

Write me about your crops and what you want. Let's get acquainted.

To the thousands who ordered from me last year I thank you very much and trust the results were such that your order will be received again this year. I keep a record of every order, so that in a moment I can refer to your name and know when you ordered and how much, and thousands of names appear each year-many since the first year I sent out a catalog.

Again thanking you and awaiting your orders, which will receive my best attention, I am, Yours truly, $\quad$ D. V. BURRELL.

\section{INDEX}

\begin{tabular}{|c|c|}
\hline paragus $\ldots \ldots \ldots \ldots \ldots$ & h Roots..... \\
\hline sparagus Roots $\ldots \ldots \ldots \ldots . \quad 2$ & ueek .... \\
\hline $.3-4-5-6$ & Lettuce $\ldots$. \\
\hline$\ldots \ldots \ldots \ldots 7-8-9$ & uskmelon and Cantaloupe.. \\
\hline aloupe and Muskmelon.. & $. .33-34-35-36-37-38-39-40-41$ \\
\hline 0 & Mustard ... \\
\hline arrots $\ldots$. & $n \ldots 47-$ \\
\hline$-13-14-15-16-17$ & $\ldots \ldots$ \\
\hline ower $\ldots \ldots \ldots \ldots \ldots$ 18-19 & kin . . \\
\hline$y \quad \ldots \ldots \ldots \ldots \ldots 20-21$ & ey $\ldots$. \\
\hline lac $\ldots \ldots \ldots \ldots \ldots \ldots 29$ & $\ldots \ldots \ldots$ \\
\hline$\ldots \ldots \ldots 29$ & ip $\ldots \ldots$ \\
\hline $.22-23-24-25-26$ & $\ldots 59-60$ \\
\hline . & $\mathrm{rb}$. \\
\hline$\ldots \ldots 27-28$ & $\ldots 61-62-63$ \\
\hline$\ldots \ldots 28$ & $\ldots \ldots 663$ \\
\hline$\ldots \ldots 30$ & $\ldots \ldots 64$ \\
\hline$\ldots \ldots \ldots 2$ & $\ldots \ldots 65-66$ \\
\hline$\ldots \ldots 74$ to 80 & to $\ldots \ldots 67-68-69-70-71-72$ \\
\hline$\ldots \ldots \ldots \ldots \ldots 29$ & p $\ldots \ldots$. \\
\hline 30 & lon \\
\hline
\end{tabular}




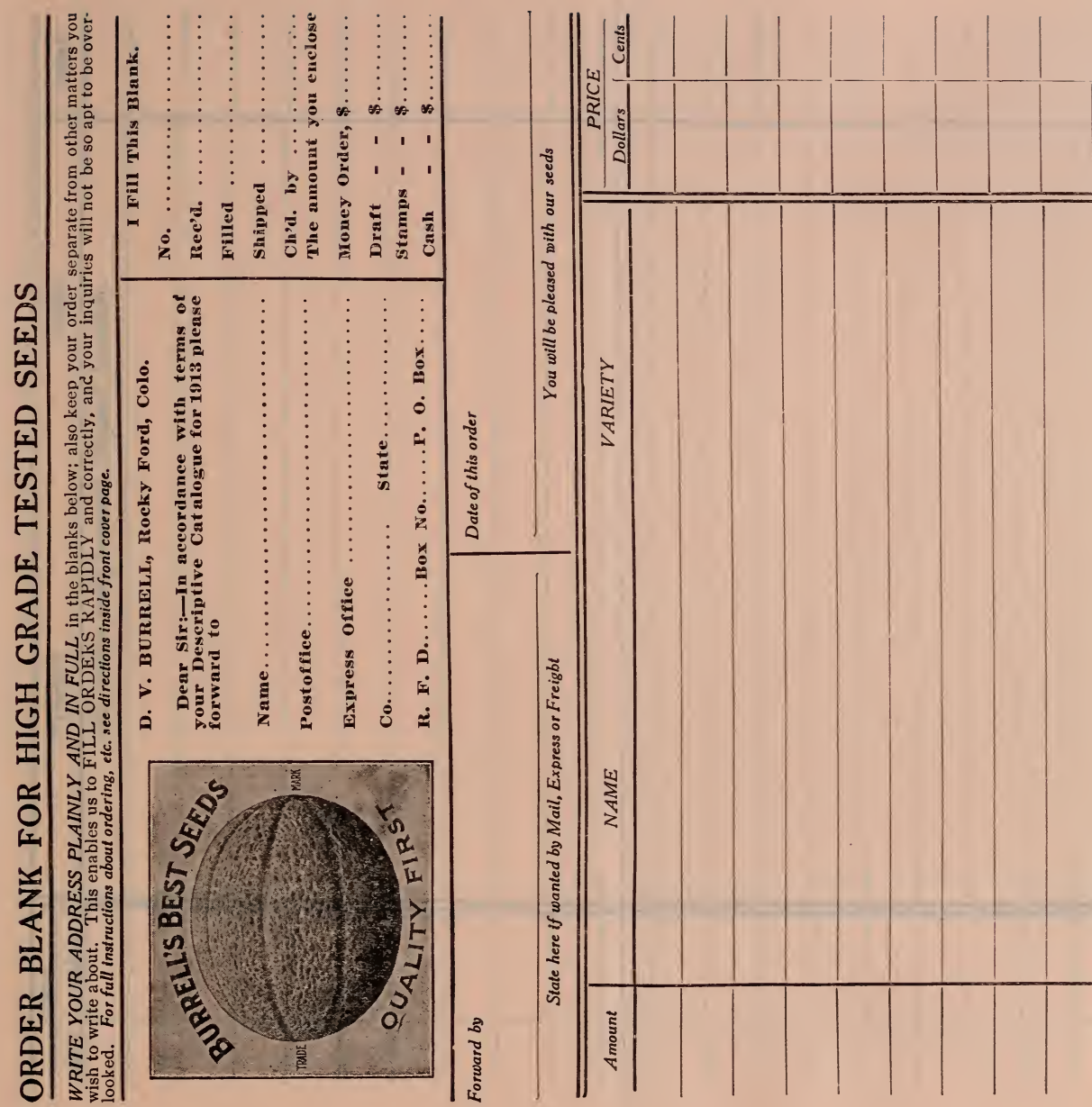




\section{(X) \\ Instructions to Purchasers}

Please follow these instructions carefully. If any mistakes occur or your order is delayed, let me hear from you promptly.

On small lots add $8 \mathrm{c}$ per pound if to go by mail.

MY TERMS ARE CASH WITH ORDER. Send Postoffice or Express Money Order, Postal Note, Bank Draft or Registered Letter. Small amounts may be in postage stamps.

C. O. D.-I will send goods C. O. D. by express where it is late in the season and you find it necessary to order by wire, but urge you to order early and avoid this expense of wiring and return charges.

HOW TO ORDER.-Always write your name, postoffice, state and express office plainly, and if possible use the order sheet. Always carry out the price of cach item.

Make all orders or checks payable to D. V. BURRELL.

SAFE ARRIVAL GUARANTEE.-I guarantee safe arrival of all seeds sent by mail or express, but request all to have their addresses plainly written. If the seeds are not received in a reasonable time, send an exact copy of the order and state kind of remittance and same will be given immediate attention.

HOW TO SHIP.-Always state how to ship heavy seeds. If to go by Freight or Express.

GUARANTEE.-It is impractical to guarantee seeds, as under improper care the best of seeds will fail. Some may be sown too shallow or too deep, in too dry ground or too wet. Some hardy seeds will stand cool weather and grow when soil is too cold for others and will cause them to decay. Insects above or below the surface may attack and destroy them. For these reasons, D. V. Burrell gives no warranty, expressed or implied, and will not in any way be responsible for the crop.

\section{No Premiums}

I do not believe my customers approve of the giving of premiums. Somebody has to pay for them. My idea is to sell to those who buy to plant, looking forward to the growing of a good garden for home use or a PROFITABLE MARKET GARDEN, and to sell these seeds as low as I can afford, quality considered, but not to cut down the quality in order to meet prices made by others. In making up this catalog I have been guided entirely by the quality of the seeds I have to offer and the supply. I trust you will favor me with your orders, which will be carefully filled.

$$
\text { Yours very truly, D. V. BURRELL. }
$$




\section{Asparagus}

Culture.-Asparagus will produce well in practically all sections of the country, and it should be in every garden. Plant the seeds thinly ( 2 to 3 inches apart) in rows 16 to 20 inches apart. This will produce the plants far enough apart so they need not be thinned. Keep free from weeds and cultivate well to get the best possible growth of plants. Transplant to permanent bed when the plants are either one or two years old. The soil for the permanent bed should be well drained and made very rich by covering with a heavy coat of barnyard manure. Disc the manure in and plow deep. Harrow severa! times as soon as plowed. Plow furrows 6 to $S$ inches deep, 4 feet apart and set the plants 2 feet apart in the furrows, spreading the roots out well. Cover with 2 or 3 inches of earth, and after the shoots begin to come up cover more, until the furrows are leveled.

Fertilize well each year with well-rotted manure. Do not cut any the first year and only a part of the crop the next year. You should not cut a full crop until 4 years old, and if well cared for, the bed will continue to produce from twelve to twenty years.

Very careful tests have proven the Palmetto superior to all others in yield and also best to withstand unfavorable weather, as this varicty does not rust easily.

Nearly all markets now call for Green Asparagus. The stalks should be cut abcut $2 \frac{1 / 2}{2}$ or 3 inches below the surface when 6 inches high. This

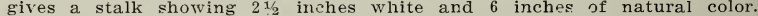
They should then be tied in bunches $2 \frac{1}{2}$ inches in diameter, $81 / 2$ inches long. Grade the asparagus, naking up the bunches from stalks of uniform size.

Make your asparagus bed where there is good air drainage, as there will he less liability to rust than if protected from the wind. Keep the soil full of humus so it will not blow badly. Give the soil a light dressing of slaked lime every two or three years; this will sweeten it and help keep away injurious insects. When the tops are brown in the fall, mow and burn them.

An cunce of seed produces about 500 plants. To be safe allow $1 \frac{1}{2}$ pounds of seed for each acre of permanent bed you wish to set; 5,500 plants set an acre; $\$ 400$ to $\$ 600$ per acre is a very common return from asparagus.

\section{Palmetto Asparagus}

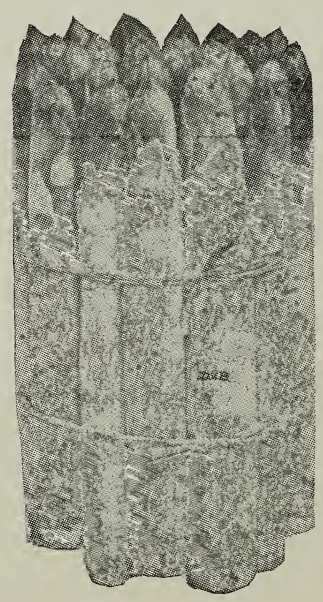

Burrell's Special Stock. This is the most valuable sort grown, as has been proven by many comparative tests. My seed is saved from a special field grown by one of the most successful growers of the country. It is large, very early and an abundant yielder. In sections subject to asparagus diseases this variety has proven most able to resist them. I recommend it for your home garden and especially to market gardens. Price-5e per pkt.; 10c per oz.; 25c per $1 / 4 \mathrm{lb}$.; 60c per lb.; 10 lbs. and up, 50c per $\mathrm{lb}$.

Conover's Colossal. A standard variety; large, productive and of good quality. Price-5c per oz.; 15e per $1 / 4 \mathrm{lb}$; $45 \mathrm{c}$ per $\mathrm{lb}$.; $10 \mathrm{lbs}$, and up, 40c per $1 \mathrm{~b}$.

Columbian Mammoth White. A variety producing large white shoots; well producing large white shoots; white asparagus. Price-5e per oz.; 15e per $1 / 4 \mathrm{lb}$.; $45 \mathrm{c}$ per $\mathrm{lb}$.; $10 \mathrm{lbs}$. and up, 40c per Ib.

Add $8 \mathrm{c}$ per pound if by mail.

\section{Asparagus Roots}

Palmetto. Grown from my special seed; fine 2-year-old plants. These prices are by freight or express as you direct. Transportation not preyou direct. Transportation not prepaid. Price-25e for $12 ; 75 e$ for $\$ 4.00$ per 1,000 in lots of 10,000 or more. 


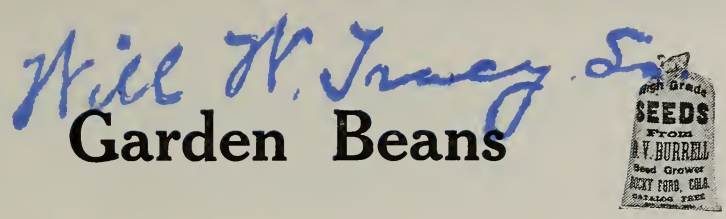

Beans like a dry and rather light soil, though they will do well in any garden soll, if not planted too early in the spring. Planting should be delayed until all danger of frost is over. Dwarfs are earliest and most hardy, as a general rule. In garden culture beans are usually planted about 2 inches deeo, in rows 18 inches apart, and 3 inches apart in the row; in field culture, in drills 2 to 3 feet apart, so as to cultivate with horse one way. Until blossoming season, frequent but shallow cultivation should be given. It is useless to expect a crop from a poorly-prepared field, or from one that needs deep stirring after planting, as cutting of the roots after the plants show bloom is very apt to kill the rines and ruin the crop. One quart will plant 100 feet of drill, and one bushel is sufficient for an acre.

Running beans, especially the Limas, are even more tender than the Dwarfs; therefore, planting must be delayed still later, or until liability to rot in consequence of cold, damp weather has passed. Plant five or six beans in each hill, about 2 inches deep, hills 3 feet apart each way. One quart of seed will be sufficient for 100 hills of Limas, and 250 to 300 hills of the other varieties.

Some market gardeners risk planting part of their crop five or six days before the average time of the last frost in the spring. so that if they are fortunate and miss the frost they will be early on the market. To afford a regular succession of crops throughout the season, plant every two weeks after the first planting until midsummer.

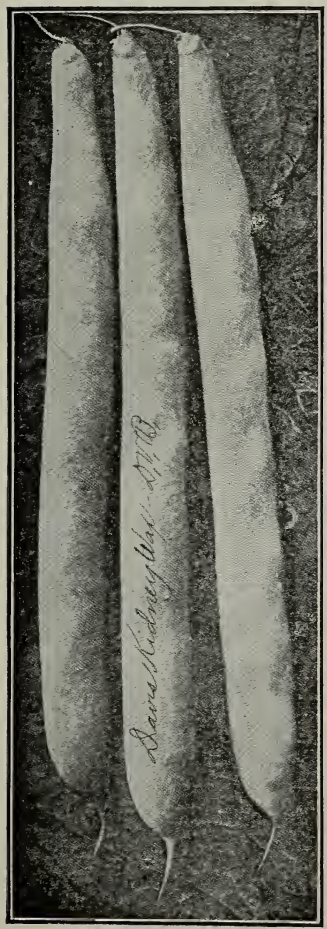

\section{Diseases}

The principal disease of beans is podspot (anthracnose). It attacks the leaves and pods, rustlike spots forming on the pods, making them unsalable.

Our soil and climatic conditions are such that beans grown here are free of pod-spot. Growers have reported that beans grown from seed obtained from us was entirely free from pod-spot.

\section{Davis White Wax Beans BURRELL'S SPOT-FREE SEED.}

This bean is a great farorite with market growers. I sell hundreds of dollars' worth in single sections of Florida, and have a large sale throughout the country. These planters report them free of pod-spot and often state that their sales amounted to from $\$ 200$ to $\$ 400$ per acre. Some growers write that after growing them in comparison with seeds from other growing sections, they do not wish to plant any but those which I produce.

The pods are long, straight, waxy yellow and stringless while young. The plants grow strong and yield an abundant crop.

They are easily picked, and the long, straight pods pack well, hold up well and look well when they reach the retail market and are offered for sale. If there were only two varieties of Wax Beans, $I$ would choose Davis White $\mathbb{W}$ ax and Wardwell's Kidney Wax.

The crop of beans is short this year compared with the demand; order early. Price-20c per pt.; 35c per qt.; $\$ 1.75$ per pk.; $\$ 6.50$ per bu.; 10 bu. lots, $\$ 6.00$ per bu.

Add $8 \mathrm{c}$ per pint, $15 \mathrm{c}$ per $q \mathrm{t}$. if by mail. 


\section{Wardwell's Kidney Wax Burrell's Spot Free Stock}

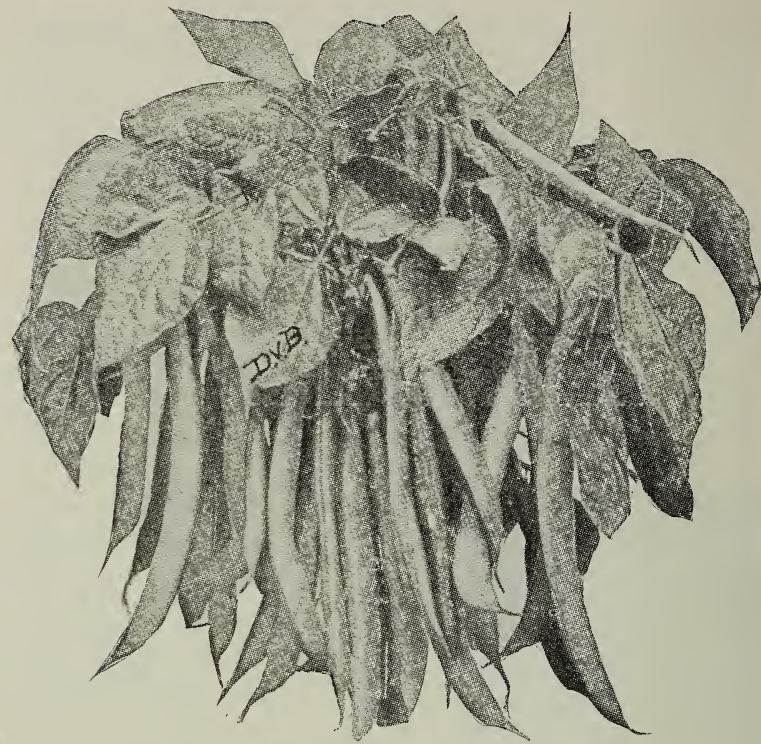

This is one of the best for market gardeners and my preference of the wax sorts for the home garden. As stated, my growing of this sort is reported spot-free from many sections where great loss is met with on account of this disease.

All of the good points of the Davis Wax apply to this. It is early, an abundant yielder, the pods are long, straight, yellow and stringless. While suitable for snap beans, the flavor is excellent and the pods, which are easily picked, hold up well for shipping. Price-20c per pt.; 35c per qt.; $\$ 1.75$ per pk.; $\$ 6.50$ per bu.; $\$ 6.00$ per bu. in $10-b u$. lots.

\section{Improved Golden Wax}

This is a decided improvement on the old Golden Wax, being a more abundant yielder and less liable to rust or spot. The pods are of good length, flat, very tender and a golden waxy color. When suitable for snap beans the pods are tender and stringless. The beans are good either for snap or dry beans. Price-20c per pt.; 35c per qt.; $\$ 1.50$ per pk.; $\$ 5.50$ per bu.; $\$ 5.00$ per bu. in $10-$ bu. lots.

\section{German Black Wax}

A vigorous grower with plenty of foliage. The pods are a creamy yellow. Very early and productive. This is a well-known sort. Price-20c per pt.; 35e per qt.; $\$ 1.50$ per pk.; $\$ 5.50$ per bu.; $\$ 5.00$ per bu. in $10-b u$. lots.

\section{Refugee Wax}

This variety possesses the valuable characteristics of the green-podded Refugee; it has handsome round pods which are stringless and remain tender a long time. The pods are waxy yellow and produced in great abundance. Price-20e per pt.; 35e per qt.; \$1.50 per pk.; \$5.50 per bu.; abundance. Price-20e per
$\$ 5.00$ per bu. in 10-bu. lots.

Add $8 \mathrm{c}$ per pint, $15 \mathrm{c}$ per quart if by mail. 


\section{Beans--Green Pod--Dwarf or Bush}

\section{Burpee's Stringless Green Pod}

This should be first choice if you prefer a green pod bean, or if you are growing for market you will find about one-half of your customers prefer a green pod bean, and to supply them you should plant one-half your acreage to this sort.

It is not equalled by any other green pod bean. It is quite hardy, extremely early, and the pods are tender, stringless and of the highest quality.

The pods are fleshy, being full and round before the beans begin to attain any size. They continue to bear a long time when kept picked off, and by planting two or three times during the season, the first planting as soon as danger from frost is past, and then later, about four weeks apart, you have snap beans covering a period of three or four months.

Price-20c per pt.; 35c per qt.; $\$ 1.50$ per pk.; $\$ 5.75$ per bu.; $\$ 5.50$ per bu. in 10-bu. lots and up.

\section{Black Valentine}

This variety is in great favor with Southern market growers. It is considered the hardiest of all beans, will stand more cool weather than any other sort. I recommend it. The pods are very attractive, being long and straight and produced in abundance. Those who grow for very early market will find this a moneymaker.

Price-15c per pt.; 30c per qt.; $\$ 1.40$ per pk.; \$5.50 per bu.; $\$ 5.00$ per bu. in 10-bu. lots and up.

\section{Refugee 1000 to 1}

A popular medium to late variety. Very productive, hence its name. It is extensively grown for pickling. The pods are well shaped-long, straight and tender.

Price-15c per pt.; 30c per qt.; $\$ 1.40$ per pk.; $\$ 5.00$ per bu.; $\$ 4.75$ per bu. in lots of 10 bu. and up.

\section{Red Valentine}

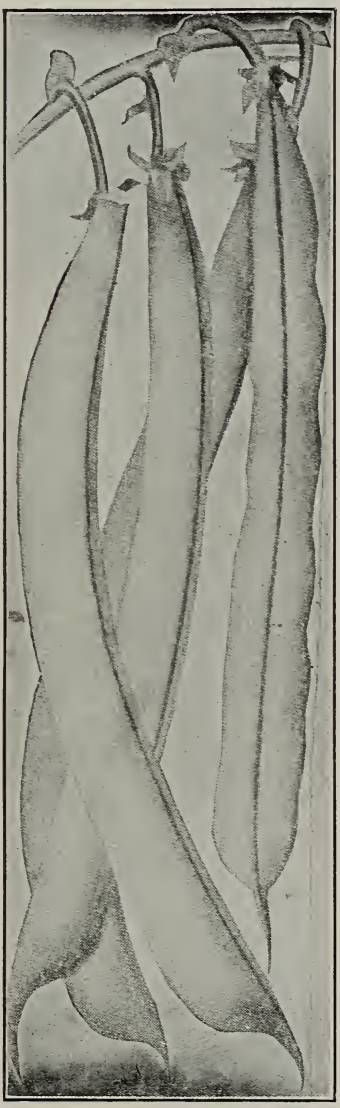

A well-known dwarf, green-podded, snap bean, usually ready for use in forty-five days after planting; a heavy yielder of good quality.

Price-15c per pt.; 30c per qt.; $\$ 1.40$ per pk.; $\$ 5.00$ per bu.; $\$ 4.75$ per bu. in lots of $10 \mathrm{bu}$. and up.

\section{Shell Beans----Mexican Beans}

This variety is grown very extensively here and gets its name from the fact that it is more sought after by Mexicans than any other variety. The beans are medium-sized and speckled; a prolific yielder and a good field bean. This is the Mexican Chili Bean.

Price-10c per pt.; 20c per qt.; $\$ 1.00$ per pk.; $\$ 3.50$ per bu.

\section{Navy Beans}

The well-known white bush variety; a good yielder. Price-10c per pt.; $20 \mathrm{c}$ per qt.; $\$ 1.00$ per pk.; $\$ 3.50$ per bu.

Add $8 \mathrm{c}$ per pt., $15 \mathrm{c}$ per qt. if by mail. 
Seeds for 1913 from D. V. Burrell, Seed Grower, Rocky Ford, Colo.

\section{LIMA BEANS}

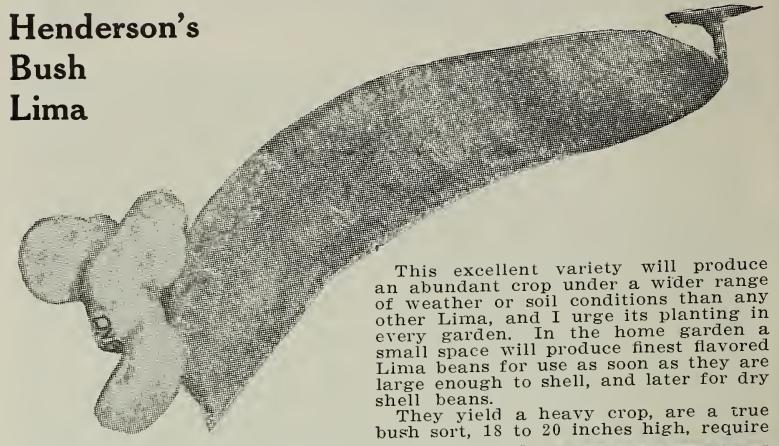

no support and are early, coming in weeks ahead of other Limas, and bearing continually until frost. The beans have the true Lima flavor, buttery, rich and tender.

Price-15c per pt.; 30c per qt.; $\$ 1.65$ per pk.; $\$ 6.00$ per bu.

\section{BURPEE'S BUSH LMA.}

A bush form of the large white Lima, which grows about 20 inches high. The beans are very large and of excellent quality, fully equal to the pole Lima, both in quality and size.

Price-15e per pt.; 30e per qt.; $\$ 1.65$ per pk.; $\$ 6.00$ per bu.

\section{BEANS-.-POLE}

\section{KING OF THE GARDEN LMIA.}

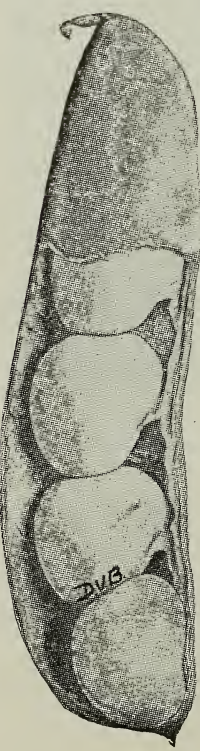

This standard market sort is one of the best for main crop. The growth is strong and the yield abundant. The bearing season continues until frost. The pods are large, containing five or six large white beans. This variety is especially valuable where the garden space is limited, as a few hills will supply a goodsized family.

Price-15c per pt.; 30c per qt.; $\$ 1.65$ per pk.; $\$ 6.00$ per bu.

The Lazy Wife's Pole Bean is entirely stringless, of fine flavor and bears an abundance of large pods which are fit for use until nearly ripe. A good, white shell bean for winter use. Price -15c per pt.; 25e per qt.; $\$ 1.50$ per plk.; $\$ 5.50$ par bu.

Old Homestead, or Kentucky Wonder, Very prolific: bears its pods in large clusters; pods green and often 8 to 10 inches $10 \mathrm{ng}$; nearly round when young, and very crisp. Price-15c per pt.; 25c per qt.; $\$ 1.50$ per

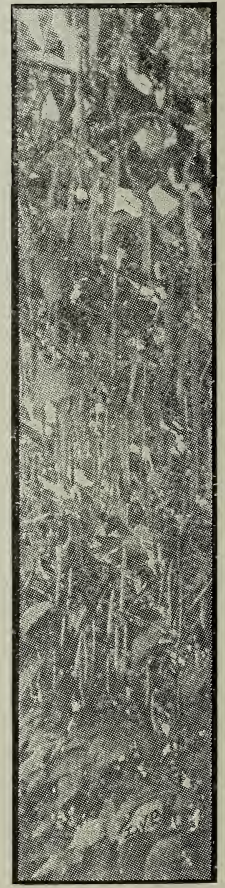
pk.; \$5.50 per bu

White Dutch Caseknife. A good shell bean, green or dry. An excellent corn bean. Price-15e per pt.; 25் per qt.; $\$ 1.10$ per pk.; \$4.00 per bu.

Red Speckled Cut Short or Cornhill is a favorite sort and much in demand to plant among corn. The pods resemble the Bush Valentine. Price-10c per pt.; 20c per qt.; $\$ 1.00$ per pk.; $\$ 3.75$ per bu.

Add $8 \mathrm{c}$ per pint or $15 \mathrm{c}$ per quart to price on all beans if by mail. 


\section{BEETS---Table}

\section{Culture}

Beets are very easily grown and one of the profitable crops for the market grower. If desirahle to be very early, they may be grown in the hotbed and transplanted, for which purpose I recommend Crosby's Egyptian.

Prepare your soil by manuring heavily and discing well before plowing, to make it easier to turn the manure under and to thoroughly mix it with the soil. Harrow as soon as plowed, making a fine, well-settled seed bed. It is a great advantage to drag or float the land. as this crushes all small clods and settles the surface well.

Plant as early in the spring as the weather will permit: Beets will stand light frosts, but care must be taken, as a heary frost would destroy them.

The rows should be 16 to 20 inches apart and the seed planted from 1 to $1 \frac{1 / 2}{2}$ inches deep. When the plants have five or six leaves thin table beets to 4 to 6 inches apart. Sugar beets and Mangel Tiurzels 10 to 12 inches apart. Plant 6 to 8 pounds of table beets or stock beets per acre and 20 pounds of sugar beets per acre.

Table beets may be sown at intervals of four weeks until the latter part of June to have tender, even-sized beets throughout the season from late summer until winter, the later planting being for siloing to use or sell during the winter.

I make a speciality of beet seed and sell thousands of pounds each year. The crops the past two years have been short, but I am making prices as low as I can for first-class stock.

\section{CROSBY'S EGYPTIAN}

\section{Burrell's Special Stock (See Cut)}

This is extremely early, being one of the first early beets. The shape is nearly round, very smooth a rich red, fine-grained and of extra quality. The tops are small, making fine bunches. They have a very distinctive bright red color and are uniform in shape and appearance.

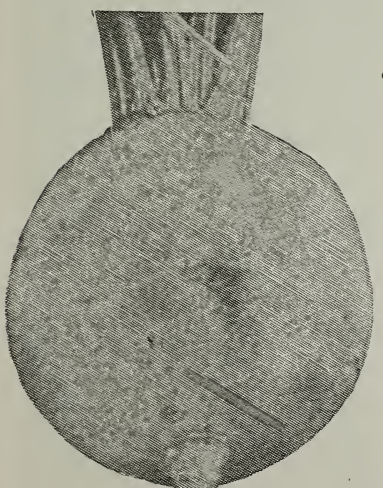

$\mathrm{The} t \mathrm{~h} p$ root is small. The type is w e 1 l illus trated in the
cut herewith. rice-5c per pkt.; 10c per oz.; 30c per 1/4 Ib.; \$1.00 per lb.; $90 \mathrm{c}$ per lb. in $10-1 b$. lots and up.

\section{Burrell's Crimson Globe}

This very valuable second early sort is a fit companion to my strain of Crosby's Egyptian. The color is darker red, shape just a little more s qu a re shouldered and a little deeper from base of top to tap root. The leaves are very dark red and tops small. It is a good beet to grow for late crop and keeps well when pitted until late in the spring. It is pitted until late in the spring. It is

Price -5e per pkt.; 10c per oz.; 30c per $1 / 4 \mathrm{lb}$; $\$ 1.00$ per lb.; 90c per lb. in 10-1b. lots and up.

\section{Early Eclipse}

Dark red, zoned with lighter shade, fine-grained, sweet, crisp and tender. The roots are nearly round; tops small, which admits of close planting. Especially good for home sarden.

Price-5e per pkt.: 10c per oz.; 30c per 1/t lb.; $\$ 1.00$ per lb.; 90e per lb. in 10-lb. lots and up.

\section{Edmand's Early Blood Turnip}

The roots of good form; round; one small tap root; the flesh deep blood red; very sweet and tender; a well-known and excellent sort. Price-5e per pkt.: 10e per oz.; 30e per 1/4

Burrell's Crimson Globe. and up. 


\section{TABLE BEETS---Continued Detroit Dark Red}

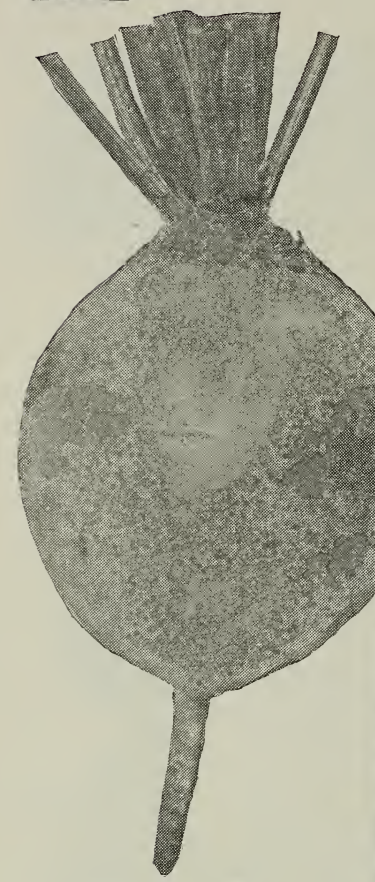

Detroit Dark Red.

\section{SUGAR BEETS} White Klein Wanzleben Sugar Beet

This is the finest variety planted for sugar and is also of great value for feeding stock. The average yield is about fifteen tons per acre and 15 per cent sugar content, while extreme yields have run over forty tons per acre. I know one tract of land which has produced an average of twenty-six tons per acre for swenty-six tons per acre for riod of nine years, the land having produced during this time two crops of vines, and this year the eighth crop of sugar beets promises thirty to thirty-five tons per acre. This only illustrates the possibilities where the proper care is given the soil.

The seed crop is very short this year.

Price-5c per oz.; 15c per $1 / 4$ lb.; 50c per lb.; 40e per lb. in lots of 10 lbs. and up.
This fine dark red beet is a leader with me. I recommend it for either the home or market garden. I also sell large quantities of it to canning factories, as its uniform shape and dark red color make it very well liked for canning.

The tops are small dark green and red, the roots globular, very smooth; the flesh a deep red, shaded with lighter red zones This beet is acknowledged by the beet seed specialis th throughout the world as the most uniform in size, shape and color, and of the highest quality.

Price-5c per pkt.; 10c per oz.; 30c per 1/4 1b.; $\$ 1.00$ per lb.; 90e per 1b. in 10-lb. lots and up.

\section{Long Smooth Dark} Blood Red

A standard late variety of good quality, keeps well through the winter; roots smooth, with few side roots. Color very dark purple; flesh dark red, of excellent quality; very good for pickles.

Price-5e per pkt.; 10e per oz.; 30c per $1 / 4$ lb.; $\$ 1.00$ per lb.; $90 \mathrm{c}$ per lb. in lots of 10 lbs. and up.

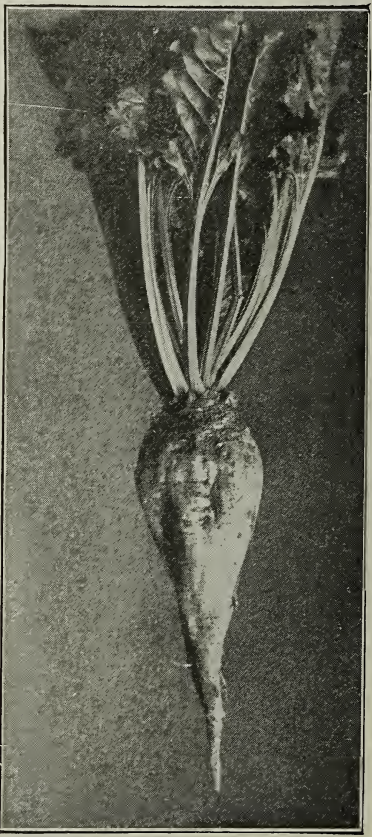

White Klein Wanzleben. 


\section{MANGEL WURZEL}

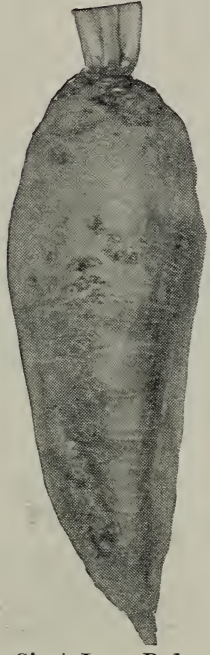

Giant Long Red.

\section{Giant Long Red}

This is the largest, heariest yielder of the Mangel Wurzels. A yield of fifty tons per acre is very commonly harrested, and with ordinary care on well-fertilized soll they should produce twenty-five to thirty tons per acre.

They contain 5 to $\bar{i}$ per cent sugar and have high feading value.

Every farmer should grow Mangel Wurzel, and a part of the crop may $w^{-1}$ be this variety. The roots are shaped as shown in cut made from a photograph. Color red, llesh white tinged with rose; grows about one-half out of the ground; easily harvested.

Price-5e per oz.; 15e per 1/4 lb.; 40c per lb.; 35c per lb. in lots of $10 \mathrm{lbs}$. and up.

\section{Golden Tankard}

Fellowish orange color. Not so long but thicker than Giant Long Red. Flesh yellow zoned with white; grows partly out of the ground; an immense yielder and preferred by many.

Price-5e per oz.; 15e per 1/4 lb.; 40c per lb.; 35c per lb. in lots of $10 \mathrm{lbs}$. and up.

\section{Giant Half Sugar Rose}

This is by many considered the greatest beet for feecing stock. It is richer in sugar than the Mangel Wurzels and not so rich as sugar beets. What it lacks in sugar it makes up in tonnage yield per acre, and not being so sweet it is less liable to injure the kidneys when fed in very large quantities, compared with sugar beets. It grows about one-half out of the ground and is excellent for all kinds of stock.

One acre of this will produce as much food value as eight to ten acres of corn.

The shape is as shown in cut made from a photograph. Color, rose above the ground, white below; flesh white, sometimes slightly tinged with rose.

Price-5̃c per oz.; 15c per 1/4 lb.; 40c per lb.; 35c per lb. in lots of $10 \mathrm{lbs}$. and up.

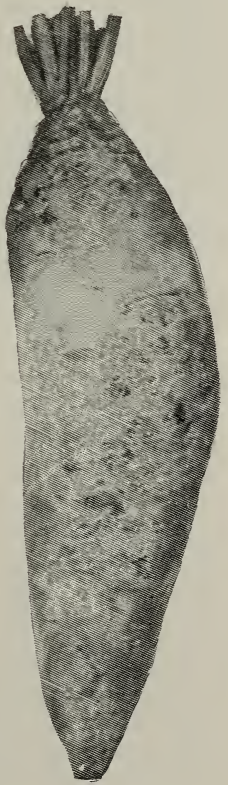




\section{Seeds for 1913 from D. V. Burrell, Seed Grower, Rocky Ford, Colo.}

\section{CARROTS}

Culture.-Any good soil is suitable; manure it well, plow deep and prepare the seed bed as for beets. It is a good plan to plant a few radish seed with the carrot, as carrot starts slowly and the radish mark the rows so they can be cultivated before the carrots come up. Plant rows same distance apart as beets and thin to about 4 inches apart in the row, or if from 2 to 4 inches apart, they need not be thinned. Cover about 1 inch deep. Cultivate often and thoroughly. Sowing may be made as early in the spring as the soil can be put in good condition, or up to June 15 to 20. Two and one-half to three pounds of seed per acre.

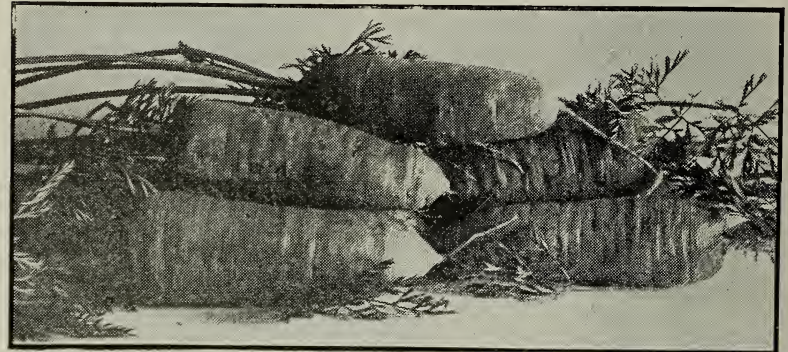

\section{Chantenay Half Long}

This excellent sort is well illustrated in above cut made from a photograph of a sample produced from my seed. The roots average about 6 inches in length, shaped as shown in cut, deep orange color, smooth, flesh very tender and first-class in every way; medium early; one of the best for market or home garden. It is very productive and easily harvested.

Price-5c per pkt.; 10c per oz.; $80 \mathrm{c}$ per $1 / 4 \mathrm{lb}$.; $\$ 1.00$ per $\mathrm{lb}$; $90 \mathrm{c}$ per lb. in 10-lb. lots and up.

OXHEART OR GUERANDI. This is a very desirable sort. The roots are thick and $4 \frac{1 / 2}{2}$ to 5 inches long, shape slightly resembling an ox's heart, hence its name. This variety grows better than any other in heavy soil, owing to the short root. The flesh is a bright orange; crisp, tender, fine-grained and sweet. An excellent sort for table, and when full grown produces a profitable crop for stock feeding. Price-5e per pkt.; 10e per oz.; 30c per $1 / 4 \mathrm{lb}$.; $\$ 1.00$ per Ib.; 90c per $1 \mathrm{~b}$. in lots of $10 \mathrm{lbs}$. and up.

DANVER'S HALF-LONG. A half-long orange carrot: very productive and suitable to almost any soil. Flesh a deep orange, fine-grained, crisp and tender. Being such an abundant bearer and of so good quality, it is considered one of the best, and the demand for it for both market and home garden is heavy. Price-5c per pkt.; $10 \mathrm{c}$ per oz.; 30c per $1 / 4 \mathrm{lb}$.; $\$ 1.00$ per per pkt.; 10c per oz.; 30 c per $1 / 4$ ib.;

LONG ORANGE. This valuable sort produces roots often 12 inches in length and 3 to $3 \frac{1 / 2}{2}$ inches in diameter at the crown, tapering regularly to the small tap root. Color a very deep orange; suitable for table use or stock feeding. Succeeds best in a deep, loamy soil; finegrained, crisp, tender and of excellent quality. Price-5c per pkt.; 10c per oz.; 30c per $1 / 4 \mathrm{lb}$.; $\$ 1.00$ per lb.; $90 \mathrm{c}$ per lb. in lots of $10 \mathrm{lbs}$. and up.

IMPROVED SHORT WHITE. One of the most productive. The roots run as much as 4 inches in diameter at the top and taper to a inches in diameter at the top and taper to a point at the small tap root; length 8 to 10
inches. They will grow to this size on good rich soil where nearly all touch each other in the rows. Thin to 4 inches apart. Color creamy white, with light green crown; flesh white, solid and of excellent quality for stock white, solid and of excellent quality for stock per $1 / 4$ lb.; $80 \mathrm{c}$ per $1 \mathrm{~b}$.; $75 \mathrm{c}$ per lb. in lots of 10 ibs. and up.

LARGE YELLOW BELGIAN. A very large yellow carrot which produces a heavy tonnage per acre, grown exclusively for stock feeding, for which purpose a large quantity of the seed is planted. Price-5e per oz.; 15c per 1/4 lb.; 55c per $1 \mathrm{~b}$.; 50e per $1 \mathrm{~b}$, in $10-\mathrm{lb}$. lots and up.

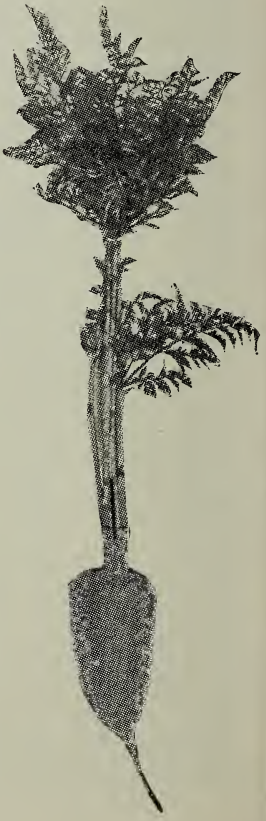




\section{CABBAGE}

Since starting in the seed business I have sold only the finest grade of cabbage seed obtainable. This seed is produced for me by the leading specialists of the world. Certain sorts which reach the highest development and produce the highest grade of seed in Denmark I have grown there; others in Holland, Germany, Long Island and Puget Sound.

With cabbage, the first point is good seed. No matter how well you care for the crop you will fail if you have not reliable seed.

\section{CULTURE.}

The soil should be rich and the preparation thorough. Cultivate, cultivate, and keep it up. If under irrigation, frequent irrigations are an adlantage, but do not water to take the place of cultivating.

For early cabbage, except in the extreme South, sow the seed in hot beds and transplant to cold frames, setting out in open ground as early as possible in the spring. For late cabbage start the plants in the open the 1 st of May in most sections and set out in the permanent row when the plants are 4 to 6 inches high. Many plant the seed in hills 10 to 12 seeds to the hill where the crop is to grow and thin to one when 3 or 4 inches high. This avoids transplanting. Continue hoeing and cultivating until the heads begin to form.

To destroy the worms, road dust or any fine dust sprinkled over the plant is effective, or spray with soap emulsion or kerosene emulsion. To store for winter use pull the cabbage and set in trenches with the heads down, covering with earth and protecting from rain. The roots should not be entirely covered until cool weather, to prevent heating. Do not trench the cabbage until just before cold weather.

I tested eighty-five varieties of cabbage this year, and among others, several new strains of which I purchased all the available seed of two sorts which I list as the "D. V. B." Cabbage and Burrell's Victor Cabbage These two are great additions to the list, and every grower should plant of them.

If you use 100 to 1,000 pounds or more seed per year write for my spe. cial offer on growing contracts. I produce thousands of pounds of seeds under contract for large planters at as low prices as good seeds can be grown.

The sorts which I list I know to be of the best.

One ounce of seed for 2,000 plants; $1 / 2$ pound of seed per acre.

\section{Burrell's Large Charleston Wakefield Cabbage}

This fine, large early cabbage is but a few days later than the very earliest small sorts, is a very strong, thrifty grower, but little bothered by insects. The heads weigh from 6 to 10 pounds, sometimes more; are very solid and profitable for the early market. My seed is grown in a section where there is nothing to be desired to permit the growing of the finest cabbage seed. You cannot buy better seed at any price.

Price-5c per pkt.; 15c per oz.; 50c per $1 / 4$ lb.; \$1.75 per lb.; $\$ 1.60$ per lb. in lots of $10 \mathrm{lbs}$. and up.

If you plant from 100 to 1,000 pounds and up of this variety, as some of my customers do, write for my contract offer to grow this seed for you.

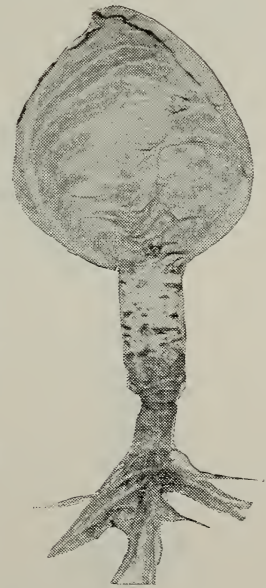

\section{Early Jersey Wakefield Cabbage}

Earlier than Charleston and smaller heads, more pointed. Extensively grown in the South. I supply large quantities of this to Southern growers, but not so much as of Charleston Wakefield.

Price-5e per pkt.; 15e per oz.; 50c per 1/4 lb.; $\$ 1.75$ per lb.; $\$ 1.60$ per lb. in lots of 10 lbs, and up. 


\section{The D. V. B. Cabbage}

I have given this fine cabbage the initials of my name for its name. It will prove one of the biggest money makers for market growers.

Iast year, 1912, I secured from the leading cabbage seed specialists of the world samples of the finest they produced, for trial. Out of eightyfive trials this sort proved the earliest, and at the same time produced solid, round white heads of the very finest quality. Think of it: Four to 6 -pound heads on an average before Jersey Wakefield would weigh 1 pound. Two weeks ahead of All Head Early or Early Flat Dutch.

One of the most prominent seedsmen of the United States, when I showed him this cabbage compared with the best of the rest, remarked: "I never saw such a cabbage; it is the finast I ever saw."

As soon as I observed how much it was ahead of the others I cabled the originator and purchased his entire supply. Now I feel I am offering the biggest money maker for the cabbage grower in the country. I would like to have a little of this seed go to every one of my customers.

See cut for shape of head and appearance when trimmed.

Price-10c per pkt.; 30c per 1/4 oz.; 55e per $1 / 2$ oz.; $\$ 1.00$ per oz. Not over 4 ozs. to one customer.

Remember, an ounce will produce 2,000 to 2,500 plants and the cost of this seed is almost nothing compared with the results which you may reasonably expect if you grow early cabbage; $\$ 4.00$ paid for 4 ounces of this seed may bring you several hundred dollars before your competitor gets on the market, and when he does get ready the quality of the "D. V. B." cabbage will give it preference on the market over other early sorts.

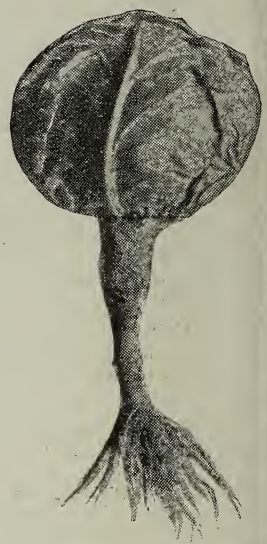

The “D. V. B." Cabbage.

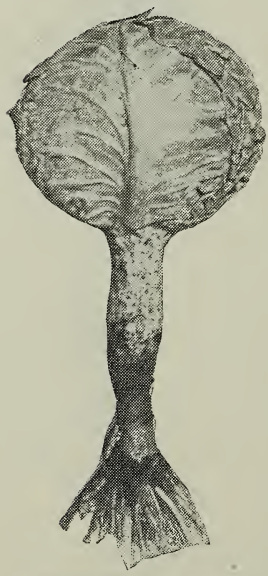

\section{Burrell's Victor Cabbage}

This is another new cabbage which $I$ am now introducing for the first time. It also is one which is just developed by a leading European specialist, and I purchased all available seed by cable as soon as I found the comparative results.

The shape is round, as shown in cut. It is good for market when the heads weigh 5 to 6 pounds and will produce fine, round, solid heads weighing 18 to 20 pounds if you wish to let it continue to grow.

The heads are solid, trim, white, are very heavy and of excellent quality. It is as early as Early Spring. Earlier than All Head Early or Early Flat Dutch, and practically every plant produces a fine head. After my experiments with all the finest sorts, if $I$ were to choose but two sorts, they would be the "D. V. B." Cabbage and Burrell's Victor Cabbage. Every cabbage grower should plant some of these in comparison with the best you have ever known, and I will be satisfied that the results will make you a permanent customer for this seed.

Price-10c per pkt.; 30c per $1 / 4$ oz.; 55c per $1 /$ oz.; $\$ 1.00$ per oz. Not over 4 ozs. to one customex.

Note the heavy stem of Burrell's Victor Cabbage. It is a strong grower, a good feeder, and you will be surprised at the tonnage it will produce per acre. 


\section{CABBAGE----Continued}

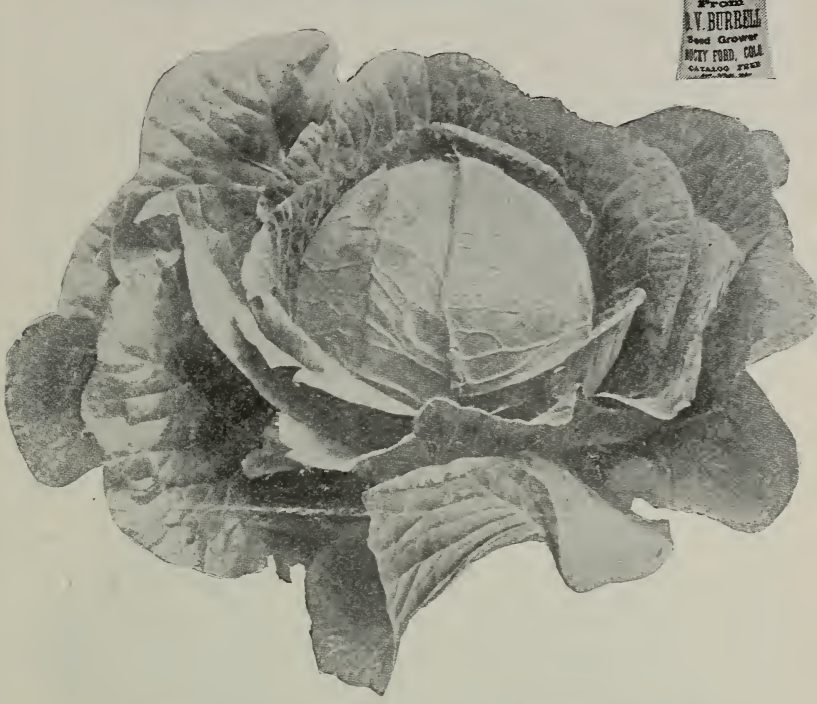

\section{New Early Cabbage, Copenhagen Market}

This new cabbage is of rery great merit, being as early as Charleston Wakefield and having the round, solid head of the Danish Ballhead. Every cabbage grower should plant some of it. This may prove to be the variety that will be a big money maker for you. The introducer says: "It is undoubtedly without a rival as the finest large round-headed early cabbage in cultivation."

The heads average 8 to 10 pounds each, very solid, with small cure and very fine quality. The plant is short-stemmed, the heads being produced very near the ground level. The leaves are closely folded and few outer leaves. The plants may be set closer than ordinary cabbage will permit.

After a thorough trial I recommend this sort either for home or market garden. The supply of this seed is very short.

Price-10c per pkt.; 20c per $1 / 1$ oz.; 70c per oz.; $\$ 1.00$ per $1 / 2$ lb.; $\$ 7.50$ per Ib.

\section{Enkhuizen Glory Cabbage}

This new sort originated near the shores of Zuyder Zee in Holland. I offer seed grown by the originator.

It is large, early, white, solid, new. The originators have this to say:

"Amongst many sorts of white cabbage, none of them combines these two desirable qualities of being early and large so well as the aforesaid sort. We can recommend this as a really early one (coming as early as the Early Dutch Flat), but at the same time maliing fine, large, ballshaped heads, particularly attractive for market purposes.

"The plants are somewhat pale green, and in proportion to the whole, malie very little outside leaves and fine large form, thin ribbed, hard heads.

"For the market one of the very best sorts."

This leaves little to be added except that I have thoroughly tested the variety and can recommend it as being a very fine sort, worthy your confidence. Do not hesitate to plant it extensively if you desire such a cabbage as is described above.

Price-5e per pkt.; 25c per oz.; 80c per 1/4 lb.; $\$ 2.75$ per lb.; $\$ 2.50$ per lb. in 10-lb. lots and up. 


\section{Cabbage----Continued}

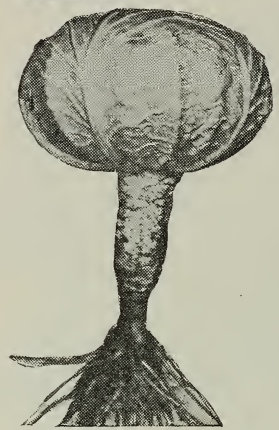

Burrell's Excelsior Flat Dutch Cabbage

This large, late variety is entitled to the name Excelsior. Practically every plant produces a fine head shaped like the illustration and weighing 15 to 20 pounds under favorable conditions. The good report comes in from large numbers of my customers and the increasing number of orders has made it necessary for me to push it much more extensively. I often sell ten to twenty pounds of seed to one large grower. You will find this an excellent late sort and a good keeper. The heads are solid, stem short and quality extra.

This variety is earlier than Premium Late Flat Dutch and much superior to it.

Price-5e per plkt.; 20c per oz.; $65 \mathrm{c}$ per $1 / 4$ lb.; $\$ 2.40$ per $1 \mathrm{~b} . ; \$ 2.30$ per $1 \mathrm{~b}$. in $10-\mathrm{lb}$. lots and up.

\section{Fottler's Brunswick Short-Stemmed Cabbage}

THIS IS THE GREATEST OF ALL SAUER KRAUT CAEBAGES.

Under ordinary conditions it will produce nearly double the crop of the average varieties. It is a very sure header and the heads average about 15 pounds.

In season it is very little later than the early pointed head sorts, but the time of maturity can be controlled by the time of starting the plants.

The stem is short and rather thick, as it is a heavy feeder; a strong grower. The cut from a photograph indicates this. Note the root system. The quality is good. Heads hard and heavy for their size.

My seed is very dependable. The plants from which it was grown were carefully selected to type.

I recommend it for your home garden and especially to those who grow for a kraut factory. A yield of 30 to 50 tons per acre is obtainable under favorable conditions.

Price-5c per pkt.: 20c per oz.; 55c per 1/4 lb.: $\$ 2.00$ per $1 \mathrm{~b}$.; $\$ 1.80$ per $1 \mathrm{~b}$. in $10-\mathrm{lb}$. lots and up.

\section{SWEDISH MARKET.}

\section{FINEST DENMARK GROWN.}

One of the finest flat head sorts in cultivation. The main crop sort for market gardeners. The price is necessarily high. The quality is also very high and considering the crop. the cost of this seed is an extremely small item. One pound of the seed will furnish item. One pound of the seed will furnish This seed was grown for me by one of the

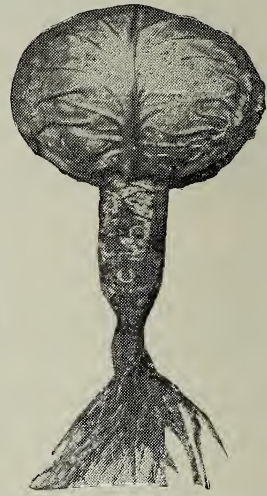
most eritical Danish growers, tion and harvesting of the stock was spared to have it the best possible qulity. The for late keeping. I recommend it heartily. Do not fail to include some of this seed in your order.

Price-5e per pkt.; 40e per oz.; $\$ 1.00$ per 1/4 lb.; $\$ 3.75$ per lb.; $\$ 3.50$ per lb. in 10-1b. lots and up.

IVINNIGSTADT. One of the best of the second early sorts, very hardy and and sure texture of its short, thick, rich dark green leaves, the variety peculiar texture of its short, thick, rich dran most other sorts. Head seems to suffer less from the cabbage worm than most other sorts. Head Leaves covered with bluish white bloom. Keeps well both summer and weaves covered with from from excessive wet, drought, lb. in 10-lb. lots and up.

PERFECTION DRUMHEAD SAVOY. Size of the Drumbead, curled leaves of the Savoy Market gardeners usually find it profitable to provide a limited quantity for discriminating customers. Price-5e per pkt.; 20c per oz.; 65e per $1 / 1 / 1 b$.; $\$ 2.40$ per $1 b$.

\section{CLUB ORDERS.}

I want to get as many as possible in each district to plant my I want to get as many as possible help produce will be of the best, and I want somebody at each place to get up club orders. If you can do this write for my offer. Do it today. 


\section{Cabbage----Continued}

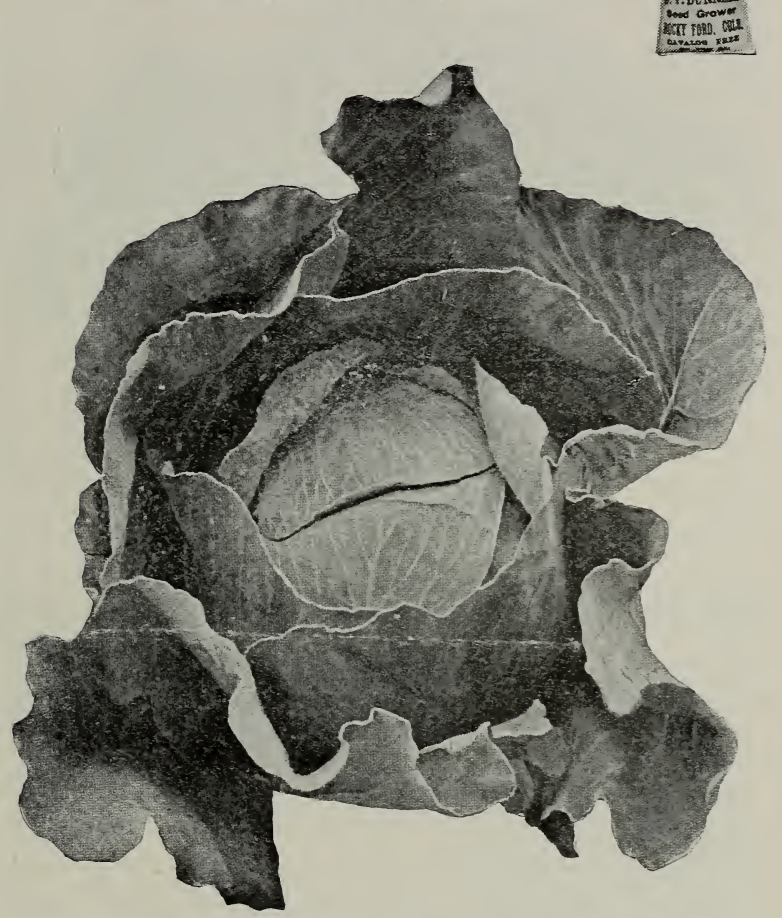

\section{Special Early Flat Dutch Cabbage}

Our seed of this variety is giving such results that the demand is growing very rapidly, and to meet it and still more largely increase it, we have increased our supply and are able to make very attractive prices.

The heads weigh 8 to 10 pounds, are very even in size, solid and of good flavor.

This is one of the best second early and stands a long time without bursting.

The plant is short-stemmed, the heads are very solid and uniform in size and shape, slightly flattened; matures as a second early sort. This sort is planted very extensively in the South.

Price-5e per pkt.; 15e per oz.; 45 c per $1 / 4$ lb.; $\$ 1.50$ per lb.; $\$ 1.40$ per lb. in 10 -lb. lots; $\$ 1.30$ per $\mathrm{lb}$. in $25-\mathrm{lb}$. lots and up.

\section{Early All-Head or Faultless}

This is an excellent sort, producing a good, solid head weighing 6 to 8 pounds from practically every plant, under fair conditions. It is among the earliest sorts and is a very profitable sort to grow. The outer leaves are few and close planting can be made, as close as 18 inches in the rows and rows 2 feet apart.

Price-5c per pkt.; 20c per oz.; 50c per 1/4 lb.; \$2.00 per lb.; $\$ 1.80$ per lb.

in 10-lb. lots and up. outside leaves and these are small and grow so close to the head that they can be planted very close together: It is round in shape, slightly flattened and very solid, even before the cabbages attain their mature size. Price-5e per pkt.; 20c per oz.; 50c per 1/4 lb.; \$2.00 per lb.; \$1.80 size. Price-5c per pkt.; 20c per oz.; 50c per 1/4 lb.; $\$ 2.00$ per $1 b . ; \$ 1.80$
per lb. in 10-lb. lots and up.

EARLY SUMMER. My seed of this variety was selected from large, solid, evenly-sized heads of excellent quality, and is of known value. This is a special market gardener's strain. It is not as well known for home gardens and not as much planted as it should be. Price-5e per pkt.; 20e per oz.; 50c per $1 / 4$ lb.; $\$ 2.00$ per lb.; $\$ 1.80$ per lb. in 10-lb. lots and up. 


\section{Cabbage----Continued}

\section{Short Stemmed Danish Round Head}

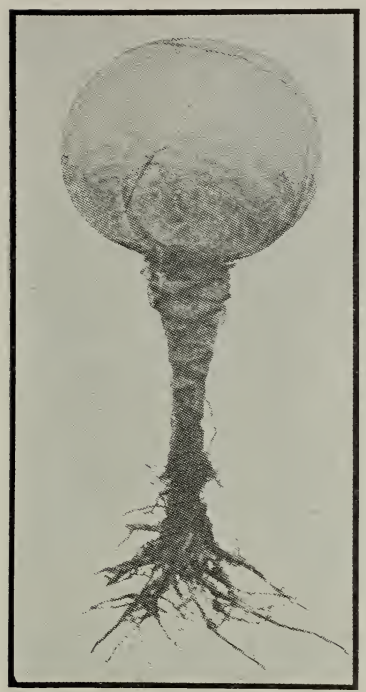

Tery hardy, handsome, very solid, of fine quality and as one of the very best keepers it is particularly desirable for distant markets or for late spring use. The plant is vigorous, compact growing, with shorter stem than most American sorts and exceedingly hardy in resisting cold and dry weather. The leaves are few but rather large, thick, smooth, bluish green covered with whitish bloom. The head is medium sized, round, very solid and stands shipment bet. ter than any other late sort.

\section{FINEST DENMARK GROWN.}

This is of the finest possible selection, grown especially for me in Denmark. It is impossible to buy better seed of this strain. Others may quote this variety at lower prices, but quality is always the first item to consider. This is an excellent market sort. I am not striving to be able to priced seeds regardless of quality, but first to offer the best possible quality and then make the price as low as I can and have sufficient pay for the most critical care and selection. I want orders from those who want the best seed money will buy at a fair price.

Large planters will find this variety excellent for late planting and a money maker. The weight of the heads of this sort trimmed is much more for the same size than the American sorts (Flat Dutch, etc.).

Price-5e per pkt.; 30c per oz.; 80c per $1 / 4 \mathrm{lb}$; $\$ 3.00$ per $1 \mathrm{lb}$; $\$ 2.80$ per $1 \mathrm{lb}$. in lots of 10 lbs, and up.

If you use large quantities of Danish Cabbage seed let me make you special prices and ship direct to you from the custom house. Some of my customers buy 500 pounds at a time.

\section{Middle Stem Danish Ballhead or Hollander}

This variety is similar to above, except the stem is longer. (See cut). It is one of the finest sorts for winter, either for the home garden or for the market. This also is grown from very carefully selected heads especially for me by one of the most critical growers in Denmark.

Price-5c per pkt.; 30c per oz.; 80c per $1 / 4 \mathrm{lb}$.; $\$ 3.00$ per $1 \mathrm{lb}$; $\$ 2.80$ per $\mathrm{lb}$. in 10-lb. lots and up.

\section{Danish Stonehead---Red}

A very valuable sort, similar to above in shape. Very solid and an excellent keeper. Many prefer this cabbage. I recommend it.

Price-5e per pkt.; 30c per oz.; 80c per $1 / \mathrm{s}$ lb.; $\$ 3.00$ per $1 b$.

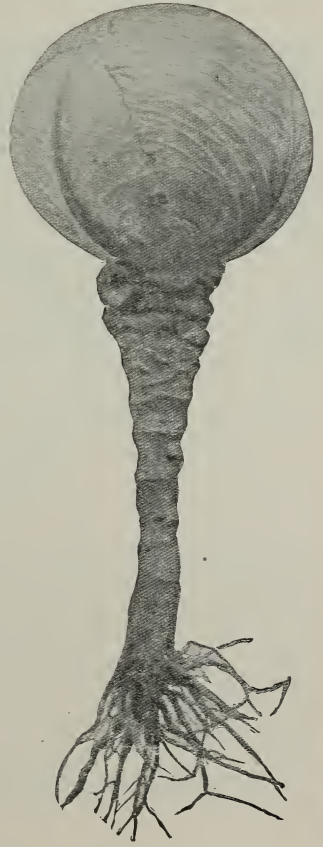




\section{CAULIFLOWER----Continued}

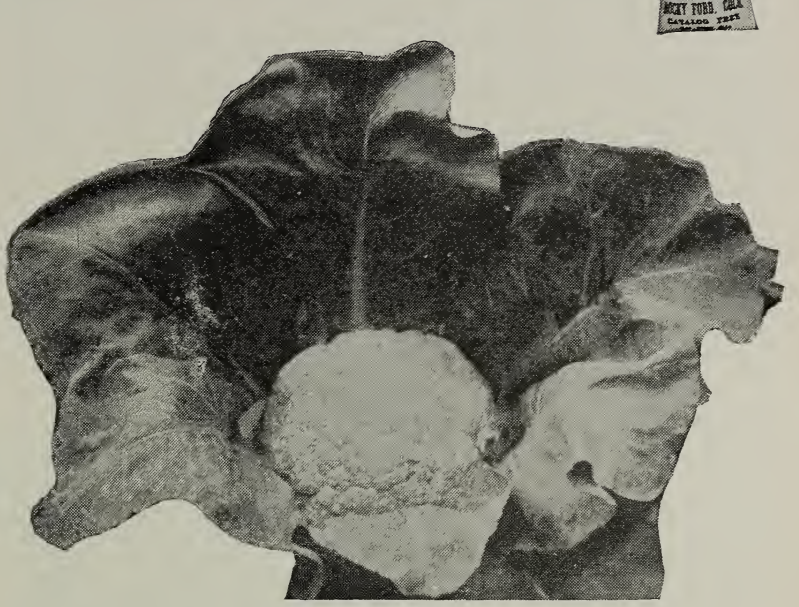

\section{Henderson's Early Snowball Cauliflower}

Its dwarf habit and short outer leaves allow it to be planted as close as 18 to 20 inches apart each way. Yery valuable for market gardeners. My stock is as fine as possible to secure.

Price-10c per pkt.; 35c per 1/8 oz.; 65c per $1 / 4$ oz.; $\$ 1.25$ per $1 / 20$ oz.; $\$ 2.25$ per oz.; $\$ 7.00$ per $1 / 4$ lb.; $\$ 25.00$ per $1 \mathrm{lb}$.

\section{Select Early Dwarf Erfurt Cauliflower}

Of dwarf habit, close, compact growth, a sure header, curd close and white; very reliable.

Price-10c per pkt.; 45c per $1 / 4$ oz.; $\$ 1.60$ per oz.; $\$ 5.50$ per $1 / 4 \mathrm{lb} . ; \$ 20.00$ per $1 \mathrm{lb}$.

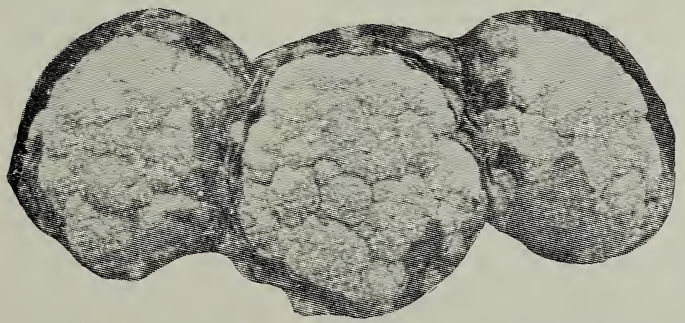

\section{Early Short Stemmed Danish Giant Cauliflower}

This is an early sort, a sure header and one of the best produced. While not quite so early as Burrell's Extra Select Early Snowball, it is equal in quality, and no matter how critical your trade or how much you have been able to do in producing califlower, you can expect to equal your best record with this seed, except as stated as to earliness.

Price-10e per pkt.; 35e per 1// oz.; 65e per 1/4 oz.; $\$ 1.25$ per $1 / 2$ oz.; \$2.25 per oz.; $\$ 7.00$ per $1 / 4 \mathrm{lb}$; $\$ 25.00$ per $1 \mathrm{~b}$.

As to Prices: I handle only the finest Danish-grown cauliflower seed obtainable. This year the crop is extra good and I am able to make a lower price. I supply a large number of the leading growers of the country. If you or your association plant large lots, let me make you special prices, either for present shipment or to be grown especially for you. 


\section{CELERY}

Celery Culture. Celery can be successfully grown with but little labor, in a good garden soil by using plenty of well-rotted manure. This should be put into the trenches, working it well into the soil, at least two weeks before the plants are transplanted into them. It delights, however, in low, moist, rich bottom land, or well drained muck soil.

Growing the Plants. It is not necessary to sow the seeds in a hot bed or cold frame, as it is apt to run to seed if started too soon, but sow in the open ground as soon as it is fit to work in April, and an additional sowing or two between this date and May 1st, will insure a plentiful supply of good plants. Sow in rows so that it can be kept free from weeds. Prepare the soil well and cover the seed very shallow and firm the soil well after sowing; also keep very moist until the seed germinates. After coming up the plants should be partially shaded for a week or ten days, and see that the soil does not get too dry. To insure good "stocky" plants, the tops should be cut back, to say within 2 inches of the crown when about 4 inches high.

Transplanting. The erening is the best time, and especially if after a shower; otherwise give them a good watering and you will lose but very few plants. Remember that it is essential that the soil be pressed firmly about each plant when set out, especially if done in a dry time. Some of our most successful growers, set on the level surface, while others prefer a broad shallow trench, only 3 or 4 inches deep. These trenches should be at least 3 feet apart for the dwarf and not less than 4 feet for the larger sorts; set plants in single rows not over 6 inches apart in the trench. Transplanting is done about the middle of June for the first early, and as late as the middle of August for the latest. Keep well cultivated, and in about six weeks "handling" should begin (never do this when wet from rain or dew). This is done to make the celery grow upright. The soil is drawn to the row from each side with an ordinary hoe. Now take all the leaves of the plant in one hand and with the other draw the soil around it, pressing firmly, being careful that no soil gets between the leaves, as it is apt to cause rust, or rot the plant. In about two weeks, or as often as is necessary to keep the leares in an upright position, more soil should be drawn to the row.

To store celery for winter, dig a trench about 12 inches wide and as deep as the celery is high. Stand the celery in this close together, packing it between two boards set about 6 inches apart. Then gradually lift the boards and pack in on each side with fine earth, making air tight, so as to keep from freezing. When freezing weather sets in cover with a board next to the top, then straw, and when hard-freezing weather cover this with earth. Covered in this way celery is ready for use in six weeks to two months after storing.

One ounce of seed produces about 2,000 plants.

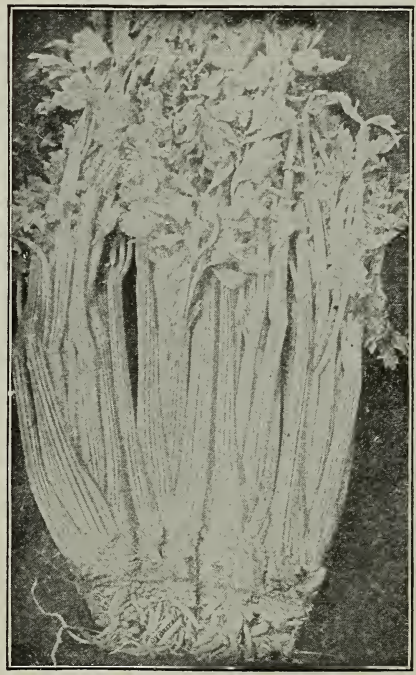

Golden Self Blanching

\section{Paris Golden}

Finest French Grown. This stock is grown expressly for me by one of the most careful French growers. It is not to be compared with $\mathrm{ch}$ h a American-grown seed.

This is a variety which requires the greatest amount of skillful attention to produce the highest grade of seed. Every plant is carefully selected and during the seedproducing season the stalks of the plants are examined to see the plants are not breaking away from good solid ing away from good solid by a careless grower is of very little value.

Last year the crop was practically a failure, and this year again not over 10 per cent of a crop was harvested. Ine result is a comparatively high price for the seed, but the crop results are such that cost of seed is practically nothing compared with the crop.

The stalks are a beautiful creamy yellow, 18 to 20 inches long, the. heart is large, solid, crisp and brittle, the flavor excellent. It ranks first.

Price-10e per pkt.; 75c per 1/. oz.; \$1.35 per oz.; \$5.25 per $1 / 4$ lb.; $\$ 20.00$ per $1 \mathrm{~b}$.

\section{Selected White Plume Celery}

This is the earliest sort and most easily blanched. The plant is a rapid grower and should be tied loosely together as soon as 5 or 6 inches high and earthed up to push the growth and blanching, also to insure close, attractively shaped branches.

My seed is of extra quality and always gives good results.

Price-5c per pkt.; $15 \mathrm{c}$ per oz.; $50 \mathrm{c}$ per $1 / 4 \mathrm{lb}$.; $\$ 1.75$ per $\mathrm{lb}$.; $\$ 1.60$ per $\mathrm{lb}$. in 5-lb. lots and up. 


\section{CUCUMBERS}

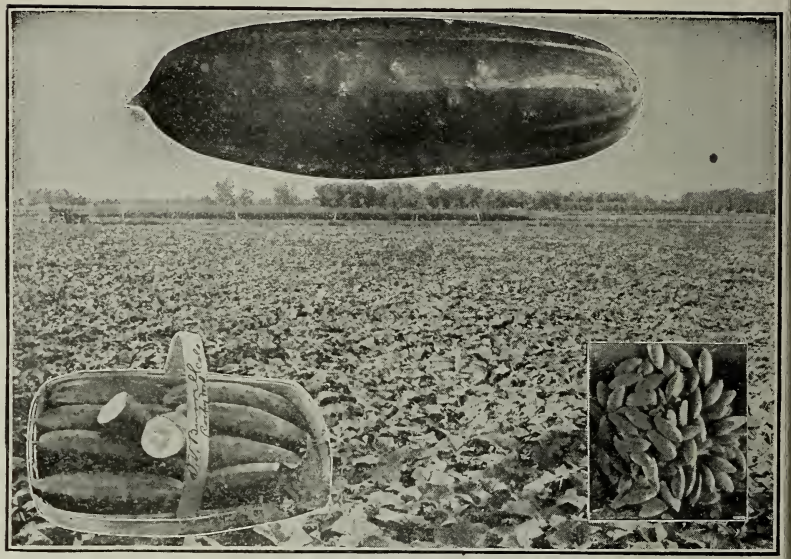

This special item has had my careful study covering the past sixteen years, during which time I have grown many thousand acres of cucumbers for seed, producing many hundred thousand pounds of seed.

I come to you for your orders for this seed, knowing what I have to offer is of the best produced.

I started the growing of cucumber seed here, and the results from my seed have been such that a very large portion of the cucumber seed of the United States is now grown here.

Each year I exercise great care to produce such seeds as will keep up this reputation. This requires carefully selected stock seeds: Soil which has not the year previous produced cucumbers, so that volunteers may be avoided; isolation from fields of other varieties; careful attention during the growing season that all off plants be destroyed; skill in harvesting, threshing, washing, curing, cleaning and testing the seed, that the best possible vitality and germination may be procured.

My constant attention to these points is your assurance that the seed which I offer is worthy your confidence. No order too small and large orders of from 1,000 to 10,000 pounds very frequently received. All orders given my very best attention.

Culture. Cucumbers thrive best in a very rich, loamy soil, not containing too much sand. A rather heavy soil is preferable to sandy soil. The most successful growers fertilize heavily with barnyard manure, scattered evenly over the surface 2 or 3 inches deep, disced thoroughly then plowed under to a depth of 6 to 8 inches, then thoroughly harrowed and floated. This gives an excellent seed bed.

You can now plant with your garden drill rows 4 feet apart, drilling in about 3 pounds of seed per acre, covering the seed about 1 inch in depth. You can follow the drill mark and cultivate before the plants come up. Cultivate often. When the plants have four to six leaves thin to one plant every 18 inches. Keep the cultivator going as long as you can get through the rows. If under irrigation, water once a week lightly and always cultivate between irrigations until the crop is laid by. Keep the cucumbers picked off as fast as they reach the size desired, as if any are allowed to ripen the plants cease to set on more fruit.

If bothered by the striped cucumber beetle, dust lightly with wood ashes into which a smal amount of turpentine has been added, or well-slaked lime mixed with fine dust and a small amount of turpentine.

Be careful not to put too much lime or ashes on the plants, as this will injure them. Keep them growing rapidly and insects have less chance to damage them.

In picking to ship for slicing it is a good plan to divide the field into thirds and pick one-third each day. If under irrigation, lay off the lands in short rows and run the water along the rows very lightly after each picking.

Always cut off the cucumbers and handle very carefully. Do not ship any culls, Throw them away and ship only the first-class specimens. They look so much better the demand is kept up-the consumer is willing to pay a better price. There is less express and package expense and your reputation for a first-class pack is kept up to the advantage of your bank account.

When the market is high manv are tempted to ship seconds. Don't do it: keep the market up with quality.

I want to call your especial attention to Burrell's Earliest of All Cucumber and Burrell's Klondike Cucumber. These two sorts are now more extensively planted by critical market growers than any other. They have been the means of a profitable business for thousands of growers. Some report from $\$ 300$ to $\$ 1,200$ per acre. 


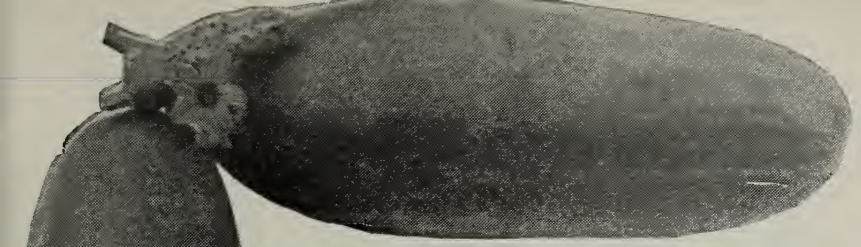

\section{Burrell's Earliest of All Cucumber}

This cucumber has proven the biggest muney maker $\epsilon$ ver planted by Florida growers, and the demand for the seed is growing very rapidly. This is a Perfected type of White spine. Earlier than any other strain of $\pi$ hite spine and as well colored as any cucumber grown.

The fruits when suitable to slice are 6 to 7 inches long, very dark green with pale green stripes about one-third the length from the blossom end; straight, square-ended and of the very finest quality.

It is a strong grower. The new blood gives it much more vigor than most old rarieties have and it sets fruits in great abundance.

For vickling it produces fruits which when suitable for bottle goods are straight, square ended and very firm. One of the large pickling companies writes me that they find it the best sort they have ever grown for this purpose and back it up with a large order for seed. The specimens shown above give you the type.

READ THIS.- Two years ago one of the leading Florida growers made a check planting of five acres of this variety and five acres each of four other varieties from other seedsmen. Now these other varieties were listed by these other seedsmen as their very best sorts for Southern planters.

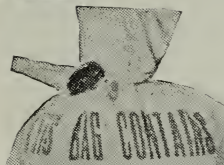

1. I.

EAPIIEST OF AL

CVOE $238 E R$ III ATIIIOS $\sin 3 x$

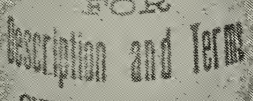

OvgR
From the first picking my Earliest of All yielded six bushels of fine slicing cucumbers and the entire trenty acres of the four other varieties vielded one and one-half bushels, and when the season was over the cash credit to the five acres of my Earliest of All was more than the cash credit to the four other varieties combined or the other twenty acres. He purchased 1,000 pounds of this seed for his 1912 planting and after the harvest of the 1912 crop stated that 10,000 to 12,000 pounds of this seed would be required to fill the demand in his district for crop 1913, and that he would rather give $\$ 3.00$ per pound for it than to plant the best of any other he knew as a gift.

Owing to the large number of very favorable reports, I grew 30,000 pounds of the seed of this variety this year, and while last year the price was rather high, I have produced an excellent crop this year and offer it at as low prices as the very ordinary sorts are usually sold. You can tie to this sort if you want the early money, the fine dark green, erenly-sized cucumbers and a big crop.

Price-5c per plkt.; 10c per oz.; 25c per $1 / 4$ lb.; 85c per lb.; 70e per lb. in 10Ib. lots and up.

Above prices delivered free by Express on large lots.

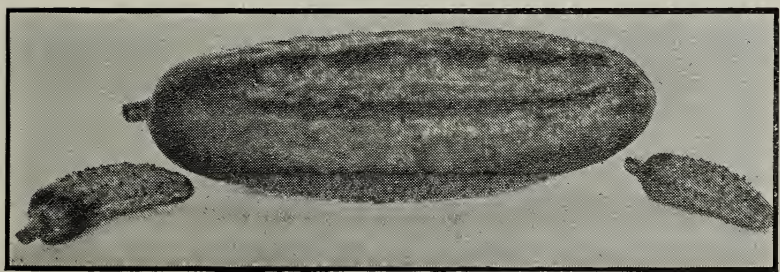




\section{CUCUMBERS--Con'd}

4. BIRPR:

Heod Grawor

4.

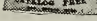

\section{Burrell's Klondike Cucumber}

This is one of my special items of my own introduction. It is a pleasure to be able to state that it has through merit and without extensive advertising worked into the favor of market growers until it is now one of the lcaders. It is without an equal for outdoor growing for slicing, producing specimens equal to the finest hot house products under favorable conditions. It is a very hardy grower. Early, yiclds abundantly and withstands unfavorable weather conditions, even when most sorts fail. When ready to ship the shape averages as in cut; color dark green with pale green stripes from the blossom end about one-third the length; flesh white and crisp, of excellent flavor; length about 7 to 8 inches. No sort produces more uniform fruits. Many single customers purchase from 100 to 500 pounds, and some more. Large lots in 1-pound sealed cloth bags.

Price-5e per pkt.; 10c per oz.; 25e per $1 / 4$ lb.; 85e per 1b.; roc per lb. in 10-lb. lots and up. Large lots delivered free by Express.

\section{Davis Perfect Cucumber--. Burrell's Special Stock}

This very valuable new sort was introduced in 1906 and I immediately secured from the introducer a considerable quantity of the seed. This I carefully planted and from the crop I selected the finest specimens for stock seed. I have kept up this selection each year and this year I grew a large acreage and am pleased to say I have seed of this valuable sort to offer my customers at prices which surely merit your orders when you consider it is one of the best possible to secure. The cucumbers shown in the basket are Davis Perfect. This cucumber is exactly the same color as Burrell's

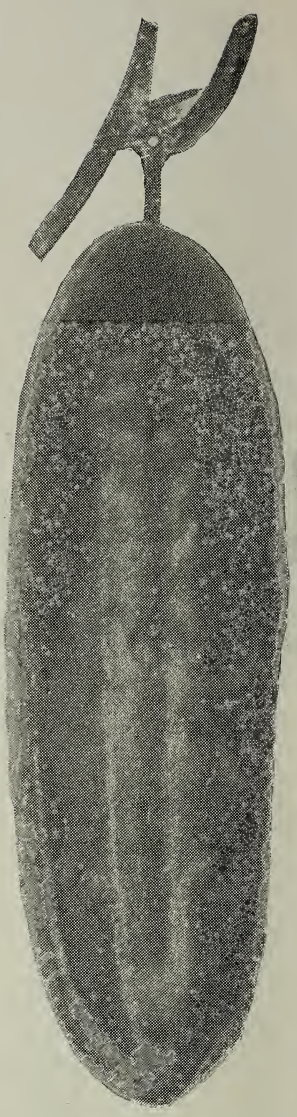

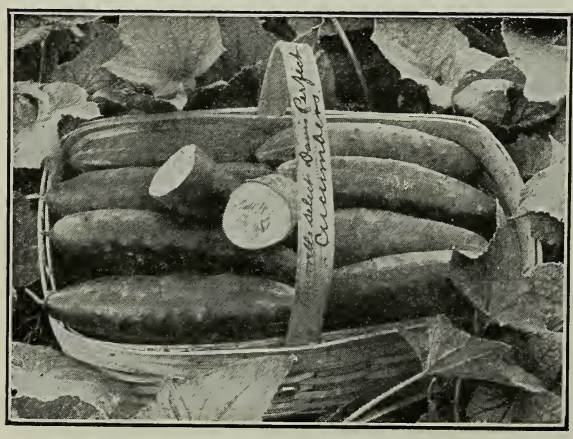

Klondike, being dark gre en. Length about 10 i $\mathrm{nch}$ es when suitable to ship, and size quite uniforn. It is uniform. It is an excellent sort house or outdoor culture.

Grown out of doors the color resembles $\mathbf{h o t}$ house grow n stock and it sells well in compet1tion with them.

Price - 5e per plkt.; 10c per oz.; 25e per $1 / 4$ lb.; $85 \mathrm{c}$ per lb.; 70c per 1b. in 10-1b. lots and up. Large lots delivered free by Express. 


\section{CUCUMBERS---Continued}

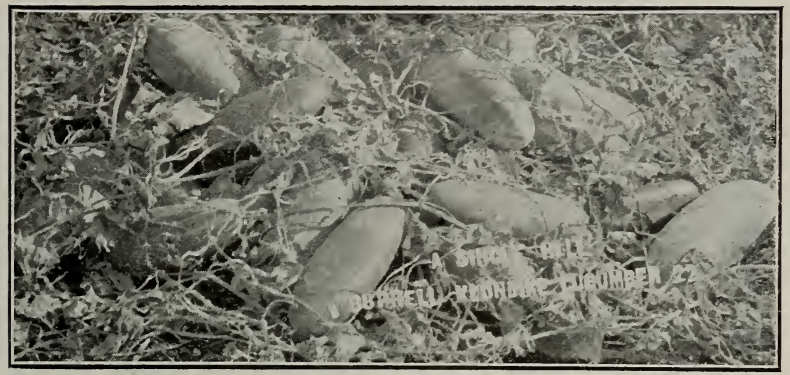

\section{Buist's Perfection White Spine Cucumber}

This stock is my own growing from the introducer's stock and as it is grown under our ideal soil and elimatic conditions, you are sure of as fine stock as it is possible to get of this well-known strain. Thousands of pounds of this seed are planted each year by Southern planters.

In shape and size it is between Burrell's Klondike and Burrell's Earliest of All. I have grown a fine crop this year and offer you a special oppor-
tunity.

Price-5c per pkt.; 10c per oz.; 20c per $1 / 4 \mathrm{lb}$; $70 \mathrm{c}$ per $1 \mathrm{~b}$.; $60 \mathrm{c}$ per $1 \mathrm{lb}$. in 10-1b. lots and up.

\section{Rawson's Arlington White Spine}

This is a very valuable strain of white spine, square ended, dark green, very prolific and preferred by many. When suitable for slicing the cucumbers are 7 to 8 inches long. Resembles Klondile very much except not so early.

Price-5e per pkt.; 10c per oz.; 20c per $1 / 4 \mathrm{lb}$.; 70c per $1 \mathrm{~b} . ; 60 \mathrm{c}$ per $1 \mathrm{~b}$. in 10-lb. lots and up.

MIPROVED ARLINGTON WHITE SPINE. This strain of White Spine produces fine green cucumbers from 8 to 10 inches long when in slicing condition, that are extra shippers. They look well in market and retain their attractive appearance a long time. The ends are slightly pointed. Price-5ac per pkt.; 10c per oz.; 20c per 1/4 lb.; 70c per lb.; 60c per lb. in 10-lb. lots and up.

EXTRA LONG WHITE SPINE. Fruits about 2 inches longer than the Arlington and square-ended, otherwise much the same. Price-5c per pkt.; 10c per oz.; 20c per $1 / 4 \mathrm{lb}$; 70c per $1 \mathrm{lb}$; $60 \mathrm{c}$ per $1 \mathrm{~b}$. in 10-1b. lots and up.

COOL AND CRISP. A strain of the White Spine, but larger and more cylindrical. Very early and exceedingly prolific. While it is esteemed most highly as a pickling sort, it is one of the very best for slicing, being tender, crisp and of fine flavor. Price-5e per pkt.; 10c per oz.; 20c per $1 / 4 \mathrm{lb}$.; $70 \mathrm{c}$ per $1 \mathrm{~b}$.; $60 \mathrm{c}$ per $1 \mathrm{~b}$. in $10-1 \mathrm{~b}$. lots and up.

EXTRA E.1RLY WHITE SPINE. This type is about midway between my Klondike and Earliest of All; the quality is excellent. Fery good for small pickles, dill pickles or slicing. Price-5e per plkt.; 10c per oz.; 20c per $1 / 4 \mathrm{lb}$.; 70c per $1 \mathrm{~b}$.; $60 \mathrm{c}$ per $1 \mathrm{~b}$. in $10-1 \mathrm{~b}$. lots and up.

CUMBERLAND. The New Cumberland combines prolificacy and vigorous growth with beauty and uniformity. It is of the hardy, white spine type, a rapid and vigorous grower, and very prolific in fruit. The pickles differ from all other hardy sorts in being thickly set with fine spines over almost the entire surface. During the whole period of growth from the time they first set until fully grown, the form is exgrowth from the time they first set until fuly grown, the form is exas for pickles. The flesh is firm, very crisp and tender at all stages. Price-5c per pkt.; 10c per oz.; 20c per $1 / 4 \mathrm{lb}$.; 70c per $1 \mathrm{~b} . ; 60 \mathrm{c}$ per $1 \mathrm{~b}$. in 10-lb. lots and up.

MPROVED LONG GREEN. My stock of this is very fine. The fruits are long, often 15 to 18 inches when fully matured. This long, slender, allthe-same shape makes it, when small, one of the finest sorts grown for pickles. It is tender and crisp and is an excellent sort for slicing, as it retains its dark green color for a long time. I offer vou extra value in this seed. This seed is more extensively grown than any other. If you order early you are sure to get it. Price-5c per pkt.; 10c per oz.; $20 \mathrm{c}$ per $1 / 4 \mathrm{lb}$.; 70c per $1 \mathrm{~b}$.; $60 \mathrm{c}$ per $\mathrm{lb}$. in $10-\mathrm{lb}$. lots and up. 


\section{CUCUMBERS---Continued}

\section{Westerfield's Chicago Pickle}

My stock of this variety illustrated above is very fine. The fruits are shaped as shown in cut. Medium length, with large, prominent spines. Color a deep green, very prolific and excellent for pickles either for short bottle pickles or dill pickles.

This variety is planted very extensively for the above purposes by large pickling concerns. Note the special prices on 100 -pound lots. If you plant larger quantities, write for special wholesale prices.

Price-5e per plkt.; 10c per oz.; 20c per 1/4 lb.; 65e per lb.; $60 \mathrm{c}$ per $1 \mathrm{~b}$, in 10 to $25-\mathrm{lb}$. lots; $55 \mathrm{c}$ per $1 \mathrm{~b}$. in 25 to $100-1 \mathrm{~b}$. lots; 50e per 1b. in 100-lb. lots.

\section{Early Short Green}

This variet $\mathrm{y}$ is also known as Early Frame. It is very early; the fruits are square-ended, uniform in shape, very firm, erisp and tender. Used very extensively for pickling, either for short bottle pickles or for dill pickles. It yields a heavy crop, the fruits being set at practically every joint on the vines.

Price-5e per pkt.; 10c per oz.; 20c per $1 / 4$ 1b.; 70e per 1b.; 65e per lb. in 10-1b. lots.

\section{Boston Pickling}

Another excellent pickler; a favorite with pickle growers. I often sell 2,000 to 3.000 pounds at a time to large picklers. Very productive fruits, small, shaped like Chicago Pickle, but with less prominent spines.

Price-5e per pkt.; 10c per oz.; 20c per $1 / 4$ lb.; roc per $1 b . ; 65 c$ per $1 b$. in 10-lb. lots and up.

\section{Fordhook Pickling}

Fruits medium sized, pointed at both ends. Bears a heavy crop of very desirable quality. Price-5c per pkt.; 10c per oz.; 20c per 1/4 1b.; 70e per lb.; 65e per Ib. in 10-lb. lots and up.

\section{Early Cluster}

Vines vigorous, producing the bulk of the crop near the roots in clusters. Fruits thick, square, ended and uniform. A very productive and valuable sort for pickles.

Price-5e per pkt.; 10c per oz.; 20c per 1/4 lb.; 70c per lb.; 65e per lb. in 10-lb. lets and up.

\section{Early Siberian}

One of the earliest sorts grown; only 3 or 4 inches long when fully ripe. Excellent for bottle pickles. Produced in clusters of two and three at practically every joint on the vine; very solid and crisp. Very few seeds.

Price-5c per pkt.; 10c per oz.; 30c per $1 / 4 \mathrm{lb}$.; $85 \mathrm{c}$ per $1 \mathrm{lb}$; 75c per $\mathrm{lb}$. in 10-lb. lots and up.

\section{Japanese Climbing}

Produces long, evenly shaped, crisp, tender fruits in great abundance. T'he vine has a greater tendency than others to fasten itself to any objects over which it may grow, hence its name. In the small garden where space is limited it may be trained on trellises to good advantage. Fine either for slicing or pickles.

Price-5e per pkt.; 10c per oz.; 30c per $1 / 4 \mathrm{lb}$.; $\$ 1.00$ per $1 \mathrm{lb.;} 90 \mathrm{c}$ per $1 \mathrm{lb}$. in $10-1 b$. lots and up.

\section{Gherkin}

Not a cucumber proper, but a little, rough, prickly fruit that grows on pretty vine with leaves something like a watermelon vine; well liked for pickling.

Price-5c per pkt.; 15c per oz.; $40 \mathrm{c}$ per $1 / 4 \mathrm{lb}$.; $\$ 1.50$ per $\mathrm{lb}$. 


\section{SWEET CORN}

\section{Country Gentleman}

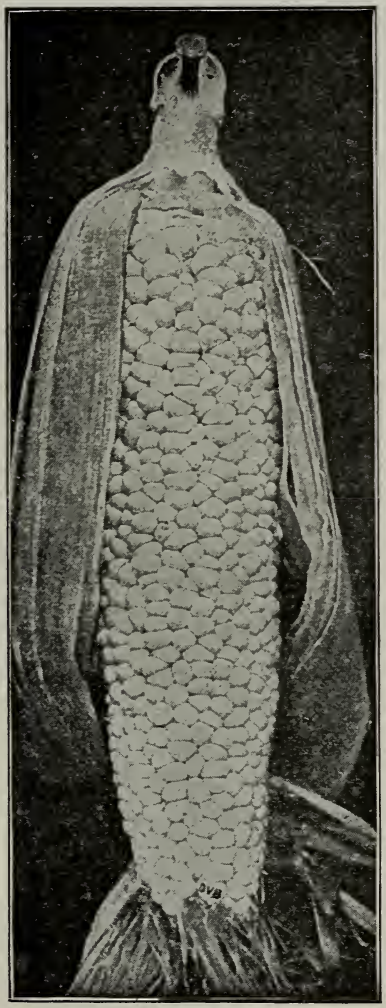

This variety produces long shoe peg kernels without rows. It is the sweetest of the sweet corns and no finer roasting ear is grown.

Having no rows, it is an excellent sort to grow where worms bother the ears, as instead of following a row into the center of the ear, thus spoiling it, they have no row to follow, and instead work around the end of the ear, which can be cut off, leaving the balance of the ear suitable for use.

Price-15̃e per pkt.; 25̃e per qt.; $\$ 1.30$ per pk.; $\$ 1.75$ per bu.

\section{Peep o' Day}

This very early sort, five to ten days earlier than any other sort, is of great value to market gardeners who make most of their money by being the first in the market. In addition to its earliness, it is sweet and tender when cooked. It is distinct in habits of growth and appearance. Stalks grow about 4 feet high and the ears abcut 5 inches long, are well formed and filled out to the tips.

Price-10e per pt.; 20c per qt.; $\$ 1.00$ per pk.; $\$ 3.25$ per bu.

White Cory. A selection from the Red Cory, over which it is a great improvement. It is fully as early, and has white kernels and white cob. Price-10c per pt.; 20c per qt.; $\$ 1.00$ per pk.; $\$ 3.25$ per bu.

Early Minnesota. One of the standard varieties, of dwarf growth, a few days later than the Cory. Large kernels of fine quality. Price-10c per pt.; 20c per qt.; $\$ 1.00$ per pk.; $\$ 3.25$ per bu.

Mammoth White Cory. A very fine, large, early sort; ears double the size of the old Cory; the same pure white color when cooked, and having white cobs, thus giving fine appearance. Price-10c per pt.; 20c per qt.; $\$ 1.00$ per pk.; $\$ 3.25$ per bu.

Shaker's Early. Large ears of excellent quality. Follows Minnesota. A fine mariset sort. Produces very attractive ears with twelve to fourteen rows of pearly white grains. Price-10e per pt.; 20c per qt.; $\$ 1.00$ per pk.; $\$ 3.25$ per bu.

Early Mammoth. An early and smaller variety of the late Mammoth. Large ears, broad kernels; quality very good. Price-10c per pt.; 20c per qt.; $\$ 1.00$ per pk.; $\$ 3.25$ per bu.

Add $8 \mathrm{c}$ per pint, $15 \mathrm{c}$ per quart, if by mail. 


\section{Burrell's Select Stowell's Evergreen Sweet Corn}

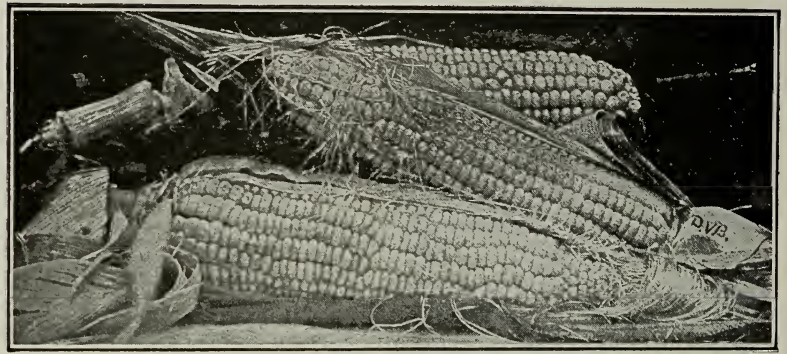

This is the leading standard variety for home use, market and canning. My stock is most carefully selected and can be depended upon to produce fine, large ears of superior quality. The stalks are of strong growth, each producing two large ears. The grains, while of good size, are long and slender, the cob being small. The grains are of rich, sugary flavor and retain their fine quality until quite advanced. My stock is entirely free from glaze or flintness; the dried grains are much shriveled.

Price-10e per pt.; 20e per qt.; $\$ 1.00$ per pk.; $\$ 3.75$ per bu.

\section{EXTRA EARLY ADAMS.}

This is not a Sugar Corn, but is earlier. The ears are short, twelverowed, and while in condition for roasting cannot be told from Sugar Corn. It will stand earlier planting than Sweet Corn and is a favorite wherever worms work hadly on early corn.

Price-10c per pt.; 15e per qt.; 60c per pk.; $\$ 2.25$ per bu.

\section{WHITE AUSTRALIAN.}

This is one of the most valuable sorts to grow where the nights are too cool for Sweet Corn or where worms bother the corn. The ears are long, 8 to 12 inches, nearly all eight-rowed. The kernels are broad and white. While tender, it makes excellent roasting ears. If Sweet Corn does not do well for you, do not fail to try this sort.

Price-10c per pt.; 20c per qt.; $\$ 1.00$ per pk.; $\$ 3.00$ per bu.

\section{BLACK MEXICAN.}

This is a very valuable sort for either early or late planting. In quality it is not excelled. Color when in roasting ear purple and white. This variety succeeds well in the Southwest especially. The ears are 6 to 8 inches long and eight-rowed. The kernels are broad and of finest flavor.

Price-10c per pt.; 20c per qt.; $\$ 1.00$ per pk.; $\$ 3.25$ per bu.

\section{Pop Corn}

\section{QUEEN'S GOLDEN.}

This is the largest sort and produces abundantly. The grains are a rich golden color and are creamy white when popped, and a single kernel will expand to nearly an inch.

Price-10c per pt.; 20e per qt.; $\$ 1.00$ per pk.; $\$ 3.00$ per bu.

\section{WHITE RICE.}

A well-known variety. I offer a very fine strain which produces larger ears than usual and yields very heavy crops. The quality is excellent.

Price-10c per pt.; 20c per qt.; $\$ 1.00$ per pk.; $\$ 3.00$ per bu.

Add $8 \mathrm{c}$ per pint, $15 \mathrm{c}$ per quart, if by mail. 


\section{A Page of Sundry Seeds Broccoli

WHITE CAPE. Heads compact, good size and of a creamy white; one of the most certain to head. Price-10c per pkt.; $30 \mathrm{c}$ per oz.; $\$ 1.00$ per

\section{Brussels Sprouts}

BEST IMPORTED DWARF. Produces many sprouts close together; a good keeper. Price-5c per pkt.; $10 \mathrm{c}$ per oz.; 35e per $1 / 4 \mathrm{lb}$; $\$ 1.35$ per $\mathbf{l b}$.

\section{Chicory}

CARGE ROOTED. Used to mix with or as a substitute for coffee. Cultivate same as carrots. Price-5e per pkt.; 10c per oz.; 25c per $1 / 4 \mathrm{lb}$.; $75 \mathrm{c}$ per lb.

\section{Collards}

TRUE SOCTHERX. Price-5c per oz.; 20c per 1/4 lb.; 65c per $\mathrm{lb}$. Add $8 \mathrm{c}$ per pourid if by mail.

\section{Celeriac}

GIANT SMOOFH PRAGLE. A very large and smooth rariety, free from side roots. A desirable sort for market and an excellent keeper. Price$5 \mathrm{c}$ per pkt.; $10 \mathrm{c}$ per oz.; $35 \mathrm{c}$ per $1 / 4 \mathrm{lb}$.; $\$ 1.20$ per lb.; $\$ 1.10$ per $\mathrm{lb}$. in 5-lb. lot;.

Add $8 \mathrm{c}$ per pound if by mail.

\section{Cress}

TRUE WATEI. Thrives only when roots and stems are very moist. It has fine flavor and should be grown wherever it can be given a sufficient supply of pure water. Price-5c per pkt.; 25c per oz.

DOUBLE CURLED. This is very early and of fine flavor. Price-5e per oz; $15 \mathrm{c}$ per $1 / 4 \mathrm{lb}$; $50 \mathrm{c}$ per $\mathrm{lb}$. Add $8 \mathrm{c}$ per pound if by mail.

\section{Endive}

GREEN CURLED WINTER. The hardiest variety; leaves dark green, which readily blanch white. Not only most useful as salad, but much used for garnishing. Price-5c per pkt.; 10c per oz.; 30c per $1 / 1 \mathrm{lb}$.

WHITE CURLED. To be used when young for early spring. Price-5e per pkt.; 10c per oz.; 30c per $1 / 4 \mathrm{lb}$. Add $8 \mathrm{c}$ per yound if by mail.

\section{Gourds}

DIPPER. This is like the Sugar Trough; has a thin, hard shell and can readily be made to serve useful purposes. Price-5c per pkt.; 10c per oz.; $35 \mathrm{c}$ per $1 / 4 \mathrm{lb}$.

JAPA NESE NEST EGG. Fruit small and creamy white; it exactly resembles the egg of a hen. Price-5c per pkt.; $10 \mathrm{c}$ per oz.; 35e per $1 / 4 \mathbf{l b}$.

SUGAR TROUGH. These gourds grow to hold from 4 to 10 gallons; shells light, but very hard and durable and readily made into useful household utensils. Price-5c per pkt.; $10 \mathrm{c}$ per oz.; $35 \mathrm{c}$ per $1 / 4 \mathrm{lb}$.

HERCULES CLUB. Longest of all. Price-5e per pkt.; 10c per oz.; 35c per $1 / 4 \mathrm{lb}$.

DISH CLOTH. Ornamental climber. The interior useful in kitchen when properly prepared. Price-5c per pkt.; 10c per oz.; 35c per 1/4 lb.

IIIED SORTS. This collection contains a great many varieties both useful and curious. Price-5c per pkt.; 10c per oz.; $35 \mathrm{c}$ per $1 / 4 \mathrm{lb}$. Add $8 \mathrm{c}$ per pound if by mail.

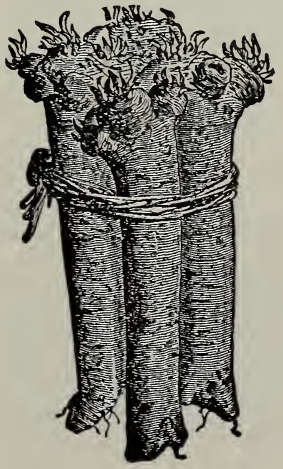

\section{Horse Radish}

Horse Radish produces no seed, but is grown from pieces of the roots. CultureMark off rows $2 \frac{1}{2}$ feet apart in rich, moist, well-prepared ground and set the pieces of roots 18 inches apart in the rows, vertically, the small end down, and the top 1 to 3 inches below the surface. Cultivate thoroughly until the tops cover the ground, when their shade will keep down the

Small Roots. 20c per doz., postpaid. By freight or express 50c per 100: $\$ 4.00$ per 1,000 . 


\section{EGG PLANT}

The Egg Plant should be more generally grown, for when well grown and properly cooked is a most delicious vegetable. The seeds germinate slowly and should be started in a strong, uniform heat, and kept constantly growing, because the young plants seldom recover if checked in their growth. Sow seeds in hot beds or warm green house in March or early
April; if no hot bed is at hand they may be grown in any
aht room where the temperature will average 75 degrees. When plants Sow seeds in hot beds or warm green house in March or early
April; if no hot bed is at hand they may be grown in any
aht room where the temperature will average 75 degrees. When plants light room where the temperature will average 75 degrees. When plants apart. Keep the bed clnsed and very warm, shading from the direct rays of the sun giving an abundance of water until the ground is warm and all danger from frosts and cold nights is past, then harden the plants by gradual exposure to the sun and air, then increase the supply of water; transplant to the open ground late in May or June into warm, rich soil, 2 or 3 feet apart each way, according to the richness of the soil. When about a foot high draw the earth up to the stems. Care should be used in cutting the fruit so as not to disturb the roots of the plants. One cunce for 2,000 plants; 4 ounces for one acre.

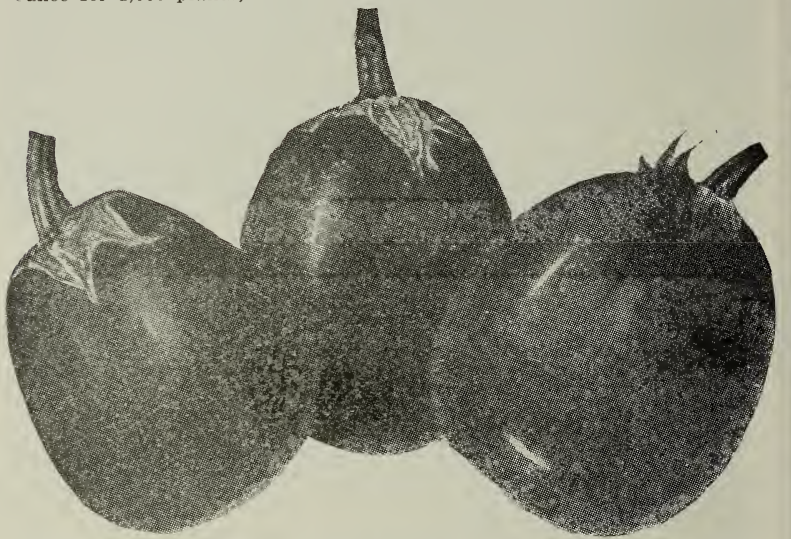

\section{Burrell's Special Gardener's Stock New York Improved Spineless Egg Plant}

My seed of this fine variety of egg plant has been selected for many years to a certain type until it is as fine as can be purchased from any source. The finest specimens from the most productive plants have been selected for stock seeds each year. The fruits are shaped as shown in cut and under favorable conditions measure 6 to 8 inches in diameter. The skin is a handsome, dark purple, flesh white, quality excellent. Market growers who plant largely will find this very desirable. Price-5e per okt.; 25e per oz.; 90c per $1 / 4$ Jb.; $\$ 3.20$ per Ib.

Add $S c$ per pound if by mail.

\section{Florida High Bush Egg Plant}

This variety has proven a money maker for Southern growers. It resists drouth and excessive moisture extremely well on account of its strong, upright growth, and as the fruits are held well up off the ground, it is very vigorous and productive. Fruits purple, of fine shape and quality; an excellent shipper and well liked on the markets where it commands top prices.

Price-10e per pkt.; 30c per oz.; $\$ 1.00$ per $1 / 4 \mathrm{lb}$.; $\$ 3.50$ per $\mathbf{l b}$.

\section{Black Pekin Egg Plant}

The fruits of this variety are longer and darker colored than New York Spineless; jet black, very glossy; a good sort.

Price-10c per pkt.; 30e per oz.; $\$ 1.00$ per $1 / 4 \mathrm{lb}$.; $\$ 3.50$ per $\mathbf{l b}$.

Add $8 \mathrm{c}$ per pound if by mail.

\section{Herbs, Sweet, Pot and Medical}

The following at $5 \mathrm{c}$ per pkt.:

Anise; has useful medicinal properties. Balm; used for balm tea or balm wine. Basil, Sweet; used for highly seasoned dishes. Bene; used in confectionery. Borage; excellent for hees, Castor Oil Plant. Caraway; used for flavoring Catnip; used for seasoning Coriander; useful culinary for flavoring. Catnip; used for seasoning. Coriander; useful culinary Florence. Hebane. Hop Seed. Horehound; for medicinal purposes. Hyssop; for medicinal purposes. Lavender; a popular aromatic herb, emitting a delightful perfume. Marjoram, Sweet; popular for seasoning. Rosemary; an aromatic herb. Saffron. Sage; the leaves are tender, tops are used in stuffing and in sauces. Savory, summer; used for seasoning; also useful as a bee food. Tansy. Winter Savory. Wormwood. 


\section{LETTUCE}

The most used of all salads; is of easy culture, requires rich, moist soil and clean cultivation, on which depends its appearance, tenderness and flavor. Foz exrly spring use, sow in a seed bed in September or October and protect through the winter in cold frames, or in the South with leaves or litter, or sow in a hot bed in early spring: as soon as the ground can be well worked, transplant in good rich ground to rows 18 inches apart and 8 inches in the rows. For a later supply plant every two weeks from the middle of April until July, choosing varieties according to their heat resistar:ce. Sow in drills $1 / 4$ inch deep, 18 inches apart, and thin large varieties to 12 inches apart in the rows. Ounce of seed makes 2,500 plants. Lottuce is divided into three classes:

First-Curled or Loose Leaved, which produce a large, loose bunch of leaves which curl beautifully and are very tender and crisp. Pretty for garnishing. These sorts are most sown for very early spring use.

Second-Heading or Cabbage Varieties, which produce heads resembling cabbage. Some of these grow to very large size and are the main crop marliet sorts for outdoor gardens.

Third-Cos or Celery Lettuce, with long head, erect and narrow leaves which blanch very quickly.

\section{Cabbage or Heading Varieties}

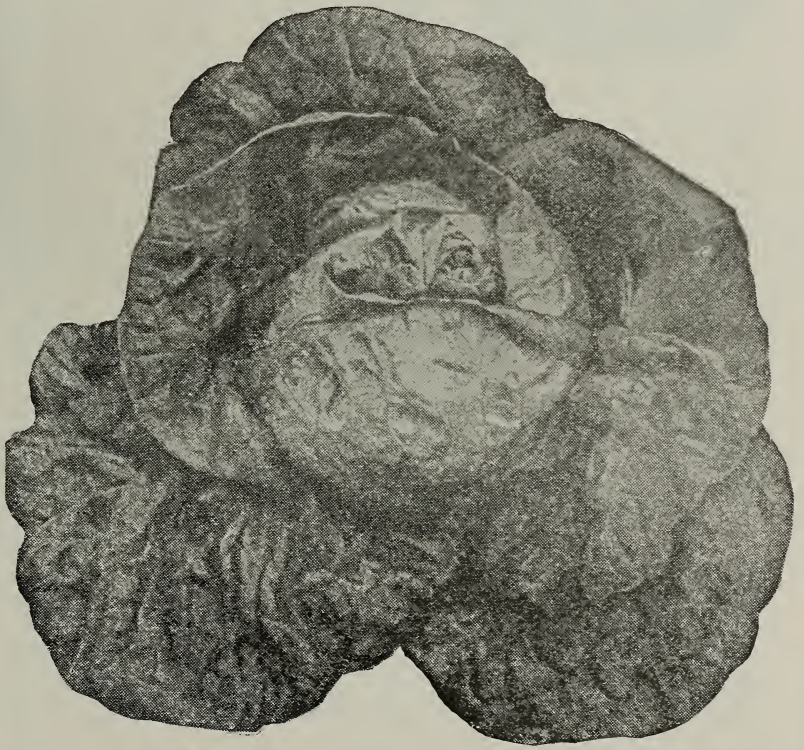

\section{Selected Market Gardener's Big Boston Lettuce}

This is a very desirable variety for forcing or outdoor culture. The heads are large and of fine quality. Planted very extensively South to ship North. Many of my customers purchase 5 to 10 pounds each of this excellent variety. Equally good for home or market garden.

Price-5c per pkt.; $10 \mathrm{e}$ per oz.; 30c per $1 / 4 \mathrm{lb}$.; $\$ 1,00$ per $1 \mathrm{~b}$.; $90 \mathrm{c}$ per $\mathrm{lb}$. in 10-1b. lots and up.

Improved Hanson. This is a standard summer lettuce; none more reliable for outdoor cultivation. The heads grow to a remarkable size, and are very solid. The outer leaves are a bright green, while the inner head presents a white appearance, as though blanched; tender and crisp and free from any unpleasant, bitter taste. It is very slow to seed, and is an ideal summer lettuce. Price-5c per pkt.; 10c per oz.; 20c per 1/4 lb.; $65 c$ per $1 \mathrm{~b}$.; $60 \mathrm{c}$ ner $1 \mathrm{~b}$. in 5 - $1 \mathrm{~b}$, lot

Salamander, or Satisfaction. Forms large, solid, compact heads, resisting summer heat and remaining long in head. Leaves smooth, thick and very tender, the inner head blanching almost white. An excellent spring, summer or fall variety. Invaluable in the Southern states. Price-5c per pkt.; 10c per oz.; $20 \mathrm{c}$ per $1 / 4 \mathrm{lb}$.; 65c per $1 \mathrm{~b}$.; $60 \mathrm{c}$ per $1 \mathrm{~b}$. in 5-lb. lots. 


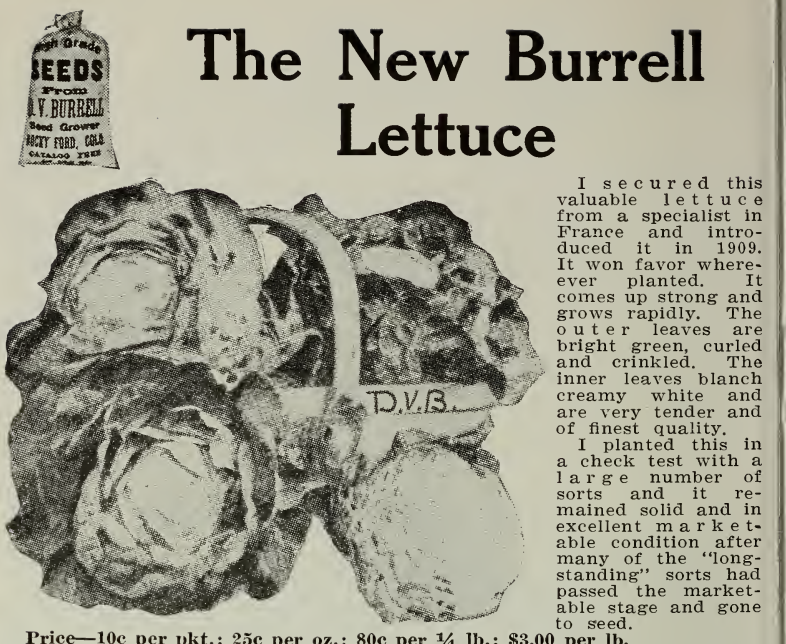

Price-10c per pkt.; 25c per oz.; $80 \mathrm{c}$ per $1 / 4 \mathrm{lb}$.; $\$ 3.00$ per $1 \mathrm{lb}$.

Early Prize Head. This popular variety produces large, loose heads of finely crimped and fringed leaves, the outer portions of which are shaded with brown. Exceedingly crisp, sweet and tender. One of the best for the home garden. Price-5e per pkt.; $10 \mathrm{c}$ per oz.; $20 \mathrm{e}$ per $1 / 4$ lb.; 65e per lb.; 60e per $1 \mathrm{~b}$. in 5 -lb. lots.

Denver Market Forcing. An early variety of head lettuce, either for forcing or open ground. It forms large heads of good, light green color, and is very slow to go to seed. The leaves are beautifully market and blistered (like the Savoy Cabbage), very crisp and tender and of excellent flavor. Price-5e per pkt.; 10e per oz.; 25 e per $1 / 4$ lb.; 70e per $1 b . ; 65 c$ per $1 \mathrm{~b}$. in 5 - $1 \mathrm{~b}$. lots.

Marblehead Mammoth. This produces the largest head of any sort. The outer leaves are light green and the center leaves are white and very crisp. Price-5e per pkt.; $10 \mathrm{e}$ per oz.; $20 \mathrm{c}$ per $1 / 4 \mathrm{lb}$; $65 \mathrm{e}$ per lb.; $60 \mathrm{e}$ per lb. in 5-1b. lots.

"Trianon" Cos or Celery Lettuce. This lettuce excels all other sorts in quality, having a crispness, tenderness and flavor peculiar to itsef and not equaled by others. The heads are long and pointed. The outside leaves should be drawn over the top and tied, when they soon form solid heads and blanch quite white and become crisp and sweet as celery stalks. It may be eaten like celery or prepared as a salad. Price-5c per pkt.; 10e per oz.; 20 e per $1 / 4 \mathrm{lb}$; $65 \mathrm{e}$ per lb.; 60c per $1 \mathrm{lb}$. in 5 -lb. lots.

Add $8 \mathrm{c}$ per pound if by mail.

\section{Curled or Loose Leaved Sorts}

Grand Rapids Forcing. There is no better forcing variety among the curled leaved sorts than the Grand Rapids, and it is quite as good for outdoor culture as other sorts. Large, beautiful leaves, very crisp and outdoor culture as other sorts. Large, beautiful leaves, very crisp and
tender. Twenty to 30 pounds have been raised from a common sash, and three crops taken off the ground. Frequently a house full of this lettuce will average $1 / 2$ pound to the plant, and occasionally a plant will weigh $1 \frac{1 / 2}{2}$ pounds. Excellent for shipping and will insure sales at sight. The soil cannot well be too rich. Price-5e per pkt.; 10c per oz.; 20e per $1 / 4$ lb.; 65e per lb.; 60 c per 1 b. in $5-1 b$. lots.

Black Seeded Simpson. The most popular sort of all the non-heading varieties. One of the best for use under glass as well as for early outdoor planting. The plants form large, loose heads; outer leaves a light, yellowish green, with inner leaves blanched almost white. Resists the heat and remains long in a good edible condition. For this reason it makes a popular variety for all market gardeners' use. Price-5e per pkt.; 10c per oz.; 20c per 1/4 lb.; 65e per lb.; 60c per lb. in 5-lb. lots.

Early Curled Simpson (Silesia). Forms a close, compact mass of leaves that are large and broad, crimped and blistered and light green in color. Not desirable for forcing with bottom heat. It is, however, recommended for planting in cold frames, and extensively grown in the open. Price-5e per pkt.; $10 \mathrm{c}$ per oz.; $20 \mathrm{c}$ per $1 / 1 / 4 \mathrm{lb}$.; $65 \mathrm{c}$ per $1 \mathrm{lb.;} 60 \mathrm{c}$ per $1 \mathrm{lb}$. in 5-lb. lots.

The New Morse. A careful selection from the Black Seeded simpson by a seed grower of large experience. Very desirable for growing under glass or out of doors. Style of growth resembles the Grand Rapids; leaves beautifully wrinkled and of brilliant green color. One of the best for spring and summer use. Quality the very best. Price-5e per pkt.; 10c per oz.; 25e per $1 / 4 \mathrm{lb}$; ; 70 e per $1 \mathrm{lb}$.; $65 \mathrm{e}$ per $1 \mathrm{lb}$. in 5 -lb. lots. Add $8 \mathrm{c}$ per pound if by mail. 


\section{Growing and Harvesting Rocky Ford Cantaloupes}

With the subject of growing and marketing cantaloupes, Rocky Ford, Colorado, is very closely associated, because here was the birth-place of the industry, and from here the industry has spread to all parts of the country and beyond it; borders, until cataloupes have become a staple product; plantings for market now aggregating approximately 100,000 acres.

The season legins from Old Mexico and extends through southern California, southern Texas and southern Florida with first shipments in May, and gradually extends northward until the last shipments of the year come from Colorado, during August and September, and continuing sometimes as late as October 15 th.

The Netted Gen, from which all the "green-meated" strains have been developed, was the first planted. This melon was nearly round, rather deeply riblued and almost inclined to be flattened from stem to blossom, heavily netted on the ribs, but without netting across sutures between the ribs, the blossom end well protected, meat green, spicy and very sweet.

From this melon selections were made to a longer type, resulting in the Thoroughbred Rocky Ford cantaloupe, illustrated on page 37, which retains all the original fine eating qualities and has a very desirable shape for crating.

Another selection developed a type slightly more nearly round and earlier, known as the Early Watters' strain. (See page 3S). This is the earliest strain grown, but does not succeed well in districts where the vines are inclined to rust. Its chief point of merit is extreme earliness. It sets a very heary first crop and ripens them within a few days after the first begin to ripen. While with this sort some growers get big returns because of the extreme earliness, the quality soon runs down, and, as some growers will not consider the effect of shipping poor melons, they send them out after the quality is poor and by the time the trade finds they are not good, these early shippers are through and have their money, and later shippers must suffer. For this reason I suggest going slow on this strain unless there is no tendency whatever for vines to rust in your district.

The latest and also highest development in Rocky Ford cantaloupes is the Select Rust Resistant, shown on page 35 . This strain has a closely laced and interlaced gray netting covering the entire surface, very slight ribs, a small, well developed blossom button, the deepest meat of all cantaloupes, colored green next the rind, changing slightly toward orange at the center, fine-grained and sweet. The seed are closely held in three lobes and do not readily shake loose in shipping; and the crowning virtue, the vines resist conditions which cause rust and continue to produce fully matured melons throughout the season. Fields that have yielded two months here at Rocky Ford still continue blooming up to frost. My adrice is, if it is only one, make this the one in selecting your variety to plant.

Of the red or salmon-meated varieties, there is the Burrell Gem, illustrated on page 39. The Burrell Gem now has an established place on the market. About 700 cars of these were shipped out of Colorado in 1912 which met with good sale. This melon is of recent introduction the first being marketed in 1904. In size it is larger than the Rocky Ford. This melon is well netted, has deep meat of sweet, spicy flavor and is an excellent shipper. They will not do well where there is much rain, as this will cause them to crack.

In growing melons for market, the first step is to get seeds of the best possible quality, as without good seed there can only be one resultfailure.

The land should be a sandy loam, well supplied with humus. A heavy oat stubble plowed under is one of the first locations. Green rye is apt to sour the ground and give poor results. In the young orchard sow vetch in the fall and turn it under two or three weeks before time to plant the melons, and you have stored up in the soil as much fertilizer value as you could purchase in commercial fertilizers for $\$ 20$ to $\$ 40$ per acre and above this have an abundance of humus. The orchard is benefited and you should produce a profitable crop of melons.

Prepare a deep, fnely pulverized and well settled seed bed. Plant ton to twelve seeds to the hill, close together, if the soil is inclined to crust, as one plant will help the other raise the crust, and the strongest should be left in thinning. Cover the seed about 2 inches deep. If hills 4 feet each way, thin to one plant when they have five to six leaves; if 6 feet each way, thin to two plants to the hill.

Cultivate frequently, deep away from the plants, but shallow close to them. When hoeing remove the crust from around the plants and replace with fine, loose soil. 


\section{Growing and Harvesting Rocky Ford Cantaloupes---Cont'd}

If under irrigation, they should be watered regularly about every two weeks and the watering continued through the ripening season to keep the vines thrifty. Many do not irrigate during the ripening season, with

the result that after a couple of weeks the melons ripen prematurely and are of poor quality.

Do not pick the melons until they will slip from the vines. This will be indicated by a slight change in color, and for long-distance shipping it is nccessary to observe very closely so you get the melons just as soon as the melon is ready to slip from the vine with a light pressure. As the season advances they should be picked very closc. Many pick what they call half-slip, i. e., when part of the stem lets loose with a light pressure: they brcak off the balance. This requires very close care not to get melons which are not yet sweet.

It is necessary to pick every day to get best results.

The most extensive growers follow the pickers with a wagon and extra picking bags, and as soon as a bag is filled it is laid upon the wagon and an empty one taken. When the wagon is loaded it goes to the packing shed and another takes its place. Smaller growers provide sleds drawn by one or two horses instead of wagons.

A trough with a canvas or burlap bottom is provided at the packing shed and the melons are very carefully taken from the bags and placed in the trough for packing.

The standard crate for the green-meated sorts is $12 \times 12 \times 24$ inches, which contains forty-five cantaloupes. The smaller cantaloupes are usually crated in pony srates, $11 \times 11 \times 24$ inches, which contain fifty-four melons. As a rule, however, the small melons are of poor quality and if no pony crates were shippcd the result would be favorable to the industry.

The melons are carefully inspected before crating for proper development and none but good melons packed, care being taken to have the pack tight.

The usual plan is to make the crate complete with the exception of nailing slats on top. A bench is provided on which the empty crate is placed, the end of the crate toward the packer being three or four inches lower than the other. The first melon is taken from the trough, bcing partially inspected as the hand moves to pick it up for proper maturity. It is turned over and inspected for defects as it passes from one hand to the other, and is placed in the lower left-hand corner of the crate. The second melon is placed in the center of the lower end, and the third in the right-hand corncr, making a tjght fit. Then the second cross row on the bottom is laid, and so on until the bottom tier is packcd. Then the second and third tiers are packed in the same manner. The expert crater can tell the size needed at a glance and seldom ever picks up a second melon to fit unless the first is a cull and must be thrown away.

Make it a rule to pack only such melons as you would wish to buy.

You can put up a very full pack by soaking the slats which you nail on top after filling the crate, as they then bend easily.

The Burrell Gems are packed in flat crates containing only one layer. Size of crate, $13 \frac{1}{2}$ inches wide, $4 \frac{1}{2}$ inches deep and 24 inches long, which contains twelve standard and fifteen smaller melons. This melon should be wrapped, each being wrapped separately in special wrapping paper. Pink is the best color.

Forty acres is about the least that should be planted for car-lot shipments, and where a grower plants less than this he should be able to foin with other growers to make up car lots unless he is near markets where his crop can be disposed of by local express shipments.

An average yield per acre of the Rocky Ford variety with the better growers is 150 standard crates per acre, with an extreme yield of 400 ; of the Purrell Gems, 450 flat crates, with an extreme of 900 flat crates.

The average price per crate net to the grower varies with the season and quality of the product from 70 cents to $\$ 3$ per crate for standard crates of the Rocky Ford variety, and 30 cents to $\$ 1.25$ per crate for the flat crates of the Burrell Gem variety.

Nearly the entire cantaloupe crop of the country is marketed by specialists who distribute to the differcnt markets, keeping close wire connections with all, to be able to place the melons where there is greatest demand and avoid over supplying any and failing to supply others. The distribution is a very important factor, but the quality of the pack has most to do with the success to the grower. "If the melons are right, they always sell quickly and command top prices. 


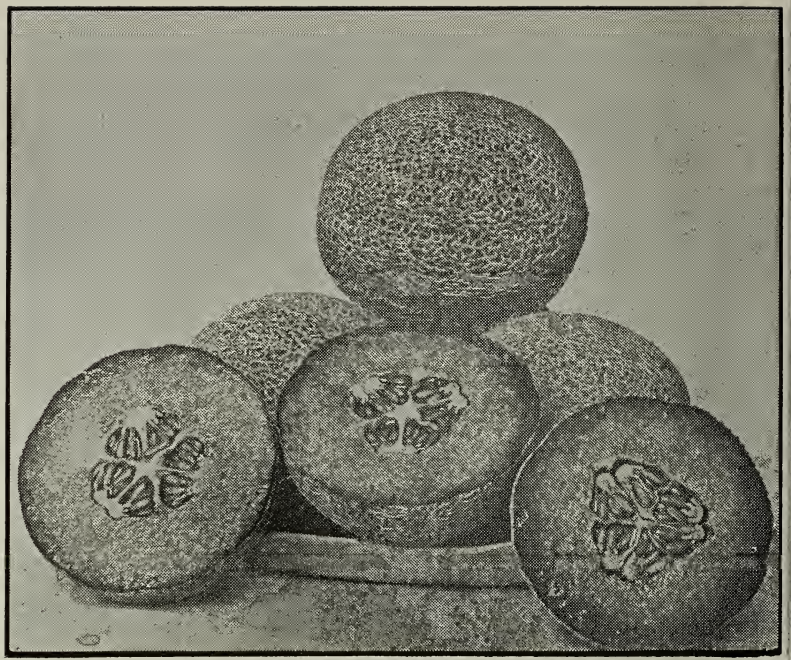

\section{Burrell's Select Eden Gem Cantaloupe Seed}

This strain of Rocky Ford Cantaloupe is favorably known in nearly all sections where Rocky Fords are grown. It is a heavy yielder, nearly all the melons are solid net, the cut above being a good illustration. The meat is deep and of excellent quality. The melons as grown here run standard size, there being but few too large and less too small. My trade amounts to several thousand pounds of this seed annually.

Stock Seed. From ideal specimens, the finest possible selection. 5c per pkt., 15e per oz., $45 \mathrm{c}$ per $1 / 4 \mathrm{lb}$., $\$ 1.55$ per lb., 10 lbs. and up, $\$ 1.50$ per $1 \mathrm{~b}$. Express prepaid.

No. 1 Seed. Cut from standard, well netted seed melons of very desirable quality, such as should be planted by market growers' associations and extensive market gardeners who appreciate the fact that good seed is necessary to produce good crops.

Price-5c per pkt., 10c per oz., 30c per $1 / 4 \mathrm{lb}$., $\$ 1.00$ per lb., $10 \mathrm{lbs}$. and up, 85e per $\mathrm{lb}$. Delivered by express.

Large lots in sealed cloth bags, $11 \mathrm{~b}$. each.

\section{Netted Rock Cantaloupe}

This strain, which is closely related to the Eden Gem, has won by merit a very favorable position with growers throughout the country, and we have taken special care to have to offer you taken special care to have to of in you sible to secure. The cut above is a good illustration of this melon. Remember, my fields of all the different strains of cantaloupes are grown exclusively for seed, and no melons shipped from the fields. Practically all netted Rocks are solid net melons and the meat is very deep. They are excellent shippers, running a large per cent standard size.

I offer two grades of seed as follows, large lots in sealed $1 \mathrm{lb}$. cloth bags:

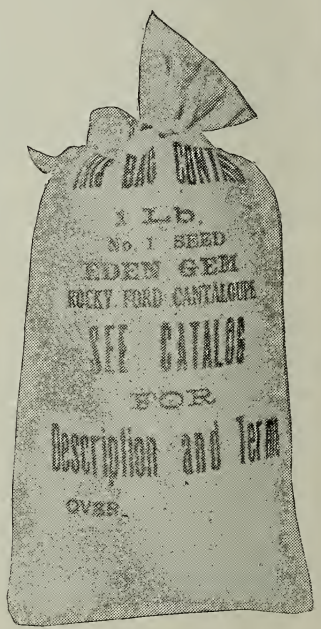

No. 1 Netted Rock. 5e per pkt., 10e per oz., 30 per $1 / 4 \mathrm{lb}$., $\$ 1.00$ per lb., 10 lbs. and up, 85e per lb. Delivered by express. These are cut from fine shippers.

Stock Netted Rock. The finest possible selection to ideal types. 5e per pkt., 15 e per oz., 45 per $1 / 4$ lb., $\$ 1.55$ per $1 \mathrm{~b} ., 10 \mathrm{lbs}$. and up, $\$ 1.50$ per $1 \mathrm{~b}$. Delivered by express. 


\section{Burrell's Thoroughbred Rocky Ford Cantaloupe}

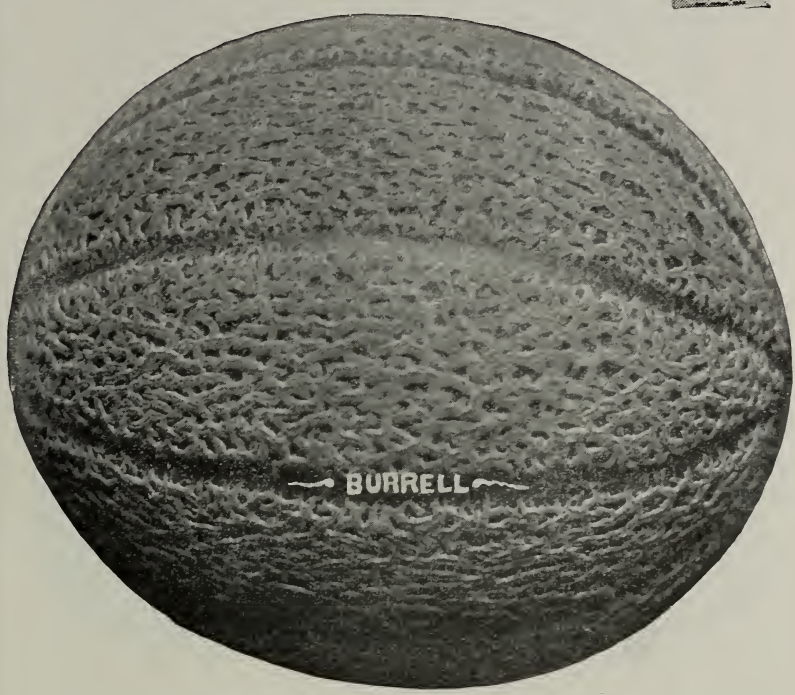

This melon has ten distinct ribs, covered with a closely laced and interlaced gray netring. The space between the netting is light green, changing to a pale slate green when ready to pick. The space between the ribs is very narrow and does not in any way weaken the melon. There is a slight tendency to net across this space, but about 90 per cent have the space well defined from stem to blossom button. The blossom end is well protected by a small button. The flesh is light green, changing very slightly toward yellow at the center. Seed cavity small. The size is very uniform. Grov'n here, about 90 per cent of the melons run standard size

It is an excellent market sort. I offer the seed in two grades, as follows, sold only in sealed packages:

\section{Stock Seed Burrell's Thoroughbred Rocky Ford Cantaloupe}

This is the finest possible selection, such as I grow seed from.

Price-5c per pkt.; 15c per oz.; $45 \mathrm{c}$ per $1 / 4 \mathrm{lb}$.; $\$ 1.55$ per lb.; $10 \mathrm{lbs}$. and up, \$1.50 per Ib.

\section{No. 1 Seed Burrell's Thoroughbred Rocky Ford Cantaloupe}

This is cut from choice melons grown exclusively for seed. Yo melons shipped from the field. It is planted extensirely by associations and other large planters. It gives excellent results.

Price-5e per pkt.; 10c per oz.; 30c per 1/4 lb.; $\$ 1.00$ per lb.; 10 lbs., $\$ 9.30 ; 20$ lbs., $\$ 18.00 ; 40$ lbs. and up, $85 \mathrm{c}$ per $\mathrm{lb}$.

Note-This melon is not as good a shipper as those varieties listed on pages 35 and 36 , but it is considered of higher flavor.

\section{Anne Arundel Musk Melon}

This very early variety is well netted, has deep green meat of very fine flavor, close grained and firm, making an excellent market melon. No: suitable to ship in standard crates, as it is too large-4 to 6 pounds.

Many report excellent crops from it, and those who have short seasons say it is their best sort.

Price-5e per pkt.; 15e per oz.; $45 \mathrm{c}$ per $1 / 4 \mathrm{lb}$.; $\$ 1.55$ per $1 \mathrm{lb}$.; $\$ 1.50$ per Ib. in $10 \mathrm{lb}$. lots and up. 


\section{CANTALOUPES}

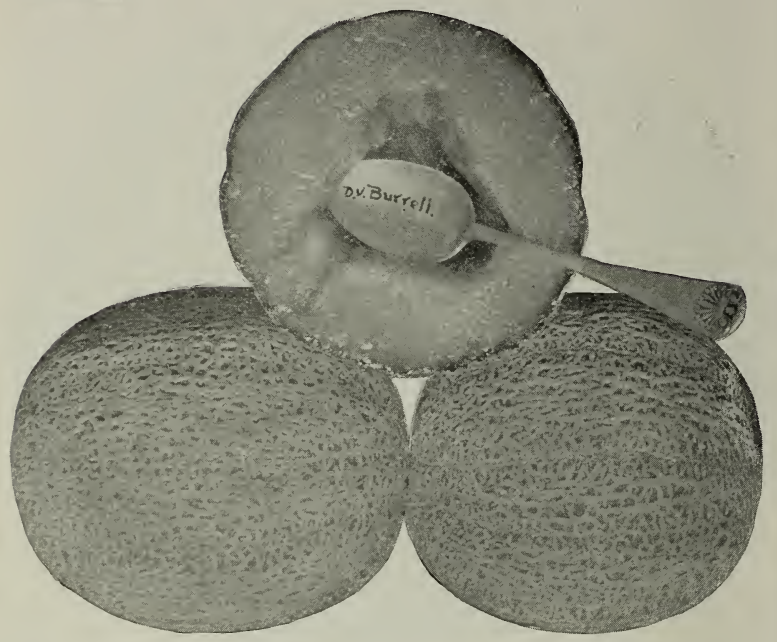

\section{Burrell's Improved Watters' Solid Net Rocky Ford Cantaloupe}

EXTRA EARLT.

DO NOT PLANT THIS VARIETY IF VINES RUST IN YOUR DISTRICT.

This SOLID NET Cantaloupe is the earliest strain of Rocky Ford Cantaloupe. It sets a very heavy first crop so that in a few days after the first crop begins to ripen large pickings are getting ripe. The netting is well developed. gray, and closely laced. The flesh is light green and of excellent quality. The seed cavity is some larger than either of the I revious strains listed.

I have sold large quantitics of this seed to market growers, with uniformly good results. My fieldis of this were very fine and produced a large crop of the finest melons.

No. 1 Seed. Grown from the finest selection of stock seeds and cut from none but standard, well-netted and fully developed melons from my own fields, grown exclusively for seed.

5c per pkt.; 10c per oz.; 30c per $1 / 4 \mathrm{lb}$.; $\$ 1.00$ per $1 \mathrm{~b} . ; 10 \mathrm{lbs}$. and up, $85 \mathrm{c}$ per lb. Delivered by express.

Stock Seed. Finest possible selection from ideal specimens. 5e per pkt; $15 c$ per oz.; 45 c per $1 / 4$ lb.; $\$ 1.55$ per $1 b . ; 10$ lbs. and up, $\$ 1.50$ per lb. Delivered by express.

\section{Montreal Market Musk Melon}

This is a very large melon, with deep pale green flesh, which is often over three inches thick. The flavor is excellent. The melon is well netted and a good shipper. Single specimens from the Montreal, Canada, district often sell at $\$ 1.25$ to $\$ 1.50$ each on the New York and Boston markets.

These melons often weigh 15 to 20 pounds.

Price-5e per pkt.; 20c per oz.; (:5e per 1/4 lb.; \$2.50 per lb.; 10 lbs. and up, \$2.25 per lb. 


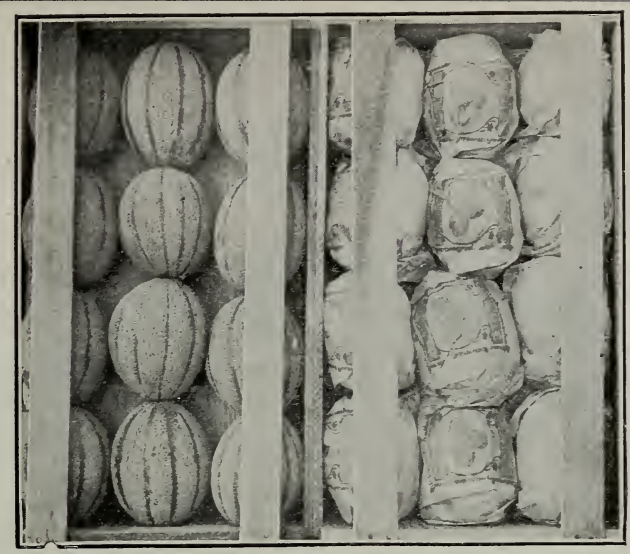

\section{The Burrell Gem Cantaloupe}

I first introduced this now famous melon on the market in 1904, marketing 41 baskets. In 1905 I grew 12 acres for market and sold $\$ 6,000.00$ worth of melons from this field. In 1906 I placed them on the Chicago and New York markets, where they sold for two to three times as much as any other melons. They have continued to keep up this good reputation and this year at Rocky Ford several hundred cars were shipped, and the growers will plant a larger portion of them next year.

The crate I am now using for lhe standard melons measures 24 inches long, $13^{1 / 2}$ inches wide, $41 / 2$ inches deep, and holds 12 melons, or 15 smaller sized melons. About 80 per cent of my melons run 12 to the crate. The small melons, 15 to the crate, do not sell as well and it is quite an advantage to get as many 12 's as possible.

This is an abundant yielder, often producing 15 to 25 melons to the hill. The meat is rich rolden color, very thick, and fine grained. The flavor cannot be excelled. The seeds are closely held in place in three lobes and do not easily shake loose. The rind is covered with a closely laced gray netting, except the narrow stripe between the ribs, which is not netted. The blossom end is well protected. Shape oblong, averaging six inches long and tapering at the ends. It is an excellent shipper and will carry nearly two weeks without ice.

I do not recommend it for planting where there is excessive rainfall, as this will cause them to crack. Be sure to get your seed from me.

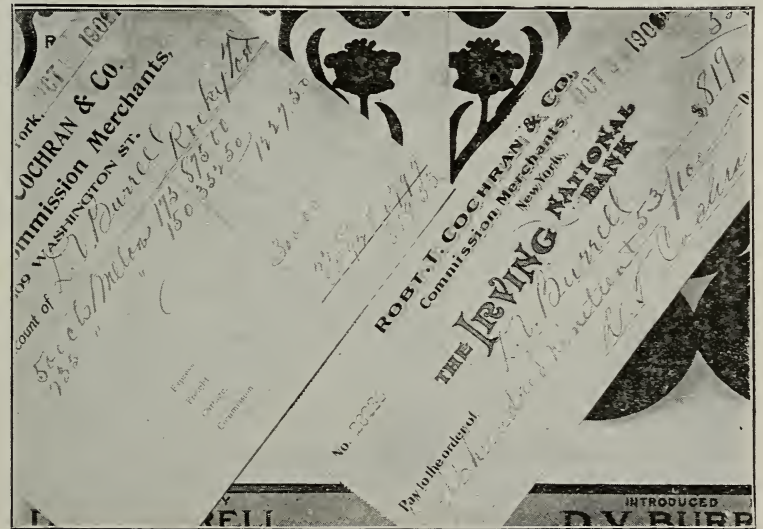

Above account of sale for a light car shows how they sell.

STOCK SEED BCRRELL GEII-The Finest Possible Selection.

Price- ̃̃c per pkt.; 15̃ per oz.; 50c per 1/4 $\mathrm{lb}$.; $\$ 1.75$ per lb.; $10 \mathrm{lbs}$. and up, $\$ 1.50$ per $1 b$.

NO. 1 SEED BLRRELL GEM, saved from fine, well-netted melons. I recommend this seed to market growers as being very desirable. This melon has brought hundreds of growers profitable returns. It will pay you to give it a trial, for if it is adapted to your soil and climate, you will be well paid for your efforts.

Price-5c per pkt.; 10c per oz.; $30 \mathrm{c}$ per 1/4 lb.; $\$ 1.00$ per lb.; $10 \mathrm{lbs}$. and up, $85 \mathrm{c}$ per lb. Above prices are delivered by express. 


\section{CANTALOUPES}

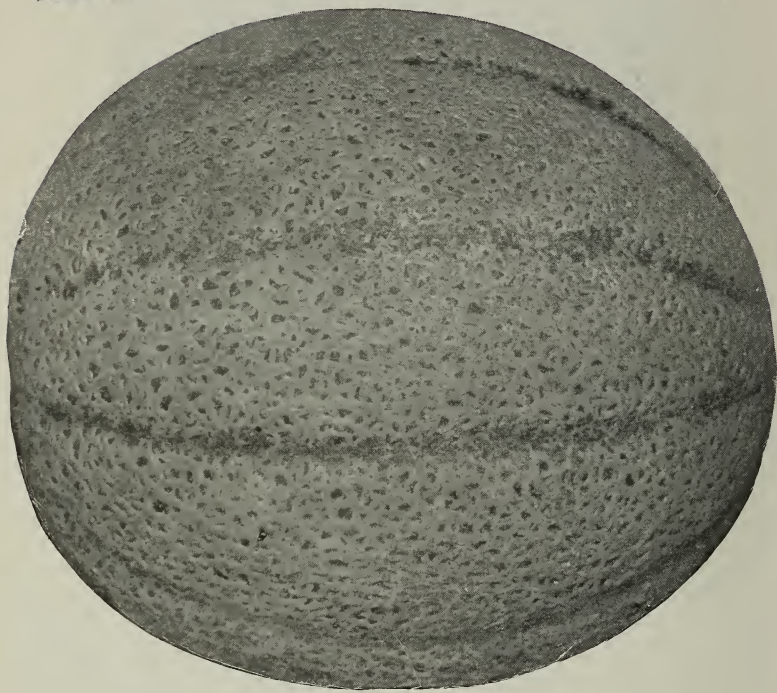

\section{Improved Hoodoo---Oblong Type}

This melon when first introduced averaged shorter from stem to blossom than from top to bottom. I have carefully selected to an oblong type and now offer seed from my fields which average fully 90 per cent of the oblong type. This has resulted in a deeper meat and a very desirable shipper. Size a little larger than the standard Rocky Ford. Color of meat a rich orange, flavor very good. The cut illustrates shape and netting. It is an excellent melon, and I recommend that you give it a thorough trial.

Price-5e per pkt.; 10c per oz.; 30e per 1/4 lb.; $\$ 1.00$ per lb.; $10 \mathrm{lbs}$. and up, 30c per, lb. Delivered by express.

THE NEW GRAND MUSKMELON. This melon of recent introduction is an improved Osage. It is about one-half the size of the original Osage, weighing 3 to 4 pounds as it grows with me. My stock is very fine, of my own growing from the originator's stock, and better cannot be had. The rind is dark green, very slightly netted, Meat deep of a rich orange color and of good quality.

Price-5e per pkt.; $10 \mathrm{c}$ per oz.; 30c per $1 / 4 \mathrm{lb}$.; $\$ 1.00$ per lb.; $10 \mathrm{lbs}$. and up, 90c per lb. Delivered by express.

OHIO SUGAR MUSK MELON. This new variety introduced last year is of special merit. It is a green fleshed Tip Top. Color of rind light slate, slightly netted. Shape nearly round; rind tough. Meat deep and a rich pea green. Weight about four pounds. This seed is very scarce. My own growing from the introducer's stock.

Price-5e per pkt.; $15 \mathrm{c}$ per oz.; 55e per $1 / 4 \mathrm{lb}$; $1 \mathrm{lb}$. and up, $\$ 2.00$ per Ib. Delivered by express.

FORDHOOK MUSK MELON. This new melon is shaped like the Jenny Lind, flattened from stem to blossom; well netted; a good yielder of excellent quality. The salmon colored flesh is very spicy. I recommend it for home gardens.

Price-5e per pkt.; $15 \mathrm{c}$ per oz.; 55e per $1 / 4 \mathrm{lb}$.; $\$ 2.00$ per lb. Delivered by express. 


\section{Muskmelons}

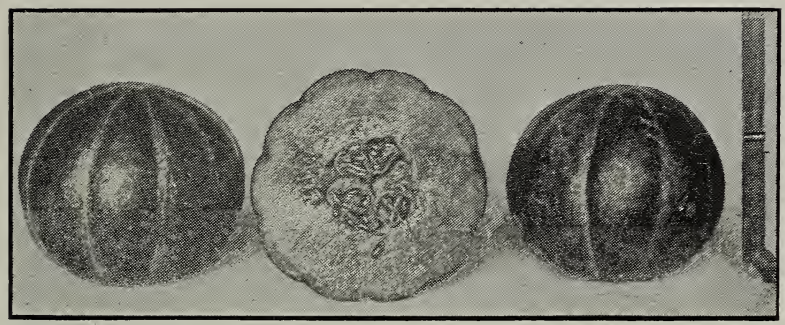

EMERALD GEM. This extra fine variety is worthy of special mention and has but few equals for the home garden, but being without netting and often cracking open when ripe, it is not a good market melon. Medium size, perfectly smooth; skin a deep emerald green with white ribs. Very attractive in appearance. Flesh salmon colored, very deep, and quality almost equal to the Rocky Ford. Do not fail to grow a few. Price-5e per pkt.; 15e per oz.; $40 \mathrm{c}$ per $1 / 4 \mathrm{lb}$.; $\$ 1.50$ per $\mathrm{lb}$.

MPROVED YELLôW CANTALóUPE. Round, flesh reddish orange; skin netted and yellow when ripe. Price-5e per pkt.; 10c per oz.; 30c per $1 / 4$ lb.; $\$ 1.00$ per 1 b.

PAUL RosE. This is a very good melon, has few equals for home garden and is a fair shipper. Fruit oval. Flesh a rich orange red. Mr. Paul Rose, who introduced this melon, has made himself famous in the produce world, and the large acreage which he grows each year finds a ready market. Price-5c per pkt.; $10 \mathrm{c}$ per oz.; 30c per $1 / 4$ lb.; $\$ 1.00$ per $1 \mathrm{~b}$.

EXTRA EARLY HACKENSACK. An improvement on the old well-known Hackensack. Same quality, ten days earlier. Price-5c per pkt.; 10c per oz.; 30c per $1 / 4 \mathrm{lb}$.; $\$ 1.00$ per $1 \mathrm{~b}$.

per oz.;
SUPERIOR. This variety is highly esteemed. The fruits are of medium size, without ribs and heavily netted. Flesh light green, excellent quality. Price-5e per pkt.; $10 \mathrm{c}$ per oz.; $30 \mathrm{c}$ per $1 / 4 \mathrm{lb}$.; $\$ 1.00$ per $\mathbf{l b}$.

OSAGE. This is a very popular melon and one of the best, owing to its fine spicy flavor and good shipping qualities. Skin dark green, slightly netted; flesh salmon color. Very productive and a long keeper. Price5e per pkt.; 10c per oz.; 30c per $1 / 4$ lb.; $\$ 1.00$ per lb.

BAY VIEW. Early, vigorous, productive, often weighs 12 to 15 pounds; flesh green and of good flavor; shape long. Price-5c per pkt.; 10c per oz.; 30c per $1 / 4$ lb.; $\$ 1.00$ per lb.

CHICAGO MARKET. Large, green-fleshed nutmeg of good quality: round and flattened. A favorite in Chicago. Price-5c per pkt.; 10c per oz.; $30 c$ per $1 / 4$ lb.; $\$ 1.00$ per $1 b$.

TIP TOP. This variety has a light, slate-colored rind; fruits are nearly round, deeply ribbed; the flesh is deep and salmon-colored; very finegrained and of desirable flavor. It is a good variety to grow for nearby markets. Price-5e per pkt.; $10 \mathrm{c}$ per oz.; 30c per $1 / 4 \mathrm{lb}$.; $\$ 1.00$ per lb.; $85 e$ yer ib. in $10-1 b$. lots and up.

All of above delivered by express.

\section{Citrons}

Add $8 \mathrm{c}$ per pound if by mail.

GREEN-SEEDED COLORADO. Fruit round; an improved variety. Price $-5 c$ per plat;; $10 \mathrm{c}$ per oz.; $20 \mathrm{c}$ per $1 / 4 \mathrm{lb}$; $65 \mathrm{c}$ per lb.; $\$ 6.00$ per $10 \mathrm{lbs}$.; $55 \mathrm{c}$ per $1 \mathrm{~b}, 25 \mathrm{lbs}$. and up.

RED-SEEDED CITRON. The old variety; good quality. Price-5e per pkt.; 10c per oz.; 20c per $1 / 4$ lb.; $65 \mathrm{c}$ per $1 \mathrm{lb}$.; $\$ 6.00$ per $10 \mathrm{lbs} . ; 55 \mathrm{c}$ per lb., 25 lbs, and up.

\section{Mustard}

\section{Add $8 \mathrm{c}$ per pound if by mail.}

WHITE ENGLISH. The leaves are light green, mild and tender when young; seed light yellow. Price-5e per oz.; 10c per 1/4 lb.; 35e lb.; $\$ 3.00$ per 10 lbs.

BRowN. Stronger and more pungent than the above. Price-5c per oz.; $10 \mathrm{c}$ per $1 / 4 \mathrm{lb}$.; $30 \mathrm{c}$ per $\mathrm{lb} . ; \$ 2.50$ per $10 \mathrm{lbs}$.

NEW CHINESE OR GIANT SOUTHERN CURLED. Very large leaves; ready for use six weeks after sowing. Plants continue to yield until after frost. Leaves are eaten, boiled like spinach. Price-5c per oz.; 15 per $1 / 4$ lb.; $45 \mathrm{c}$ per lb.; $\$ 3.50$ per $10 \mathrm{lbs}$.

OSTRICH PLUME. This is a valuable sort; produces large, curled leaves of excellent quality. If you enjoy a dish of greens this will please you, and it is a valuable market sort, being ready very early in the spring. Price-5c per oz.; 15e per $1 / 4$ lb.; 55e per lb.; $\$ 5.00$ per 10 lbs. 


\section{Watermelons}

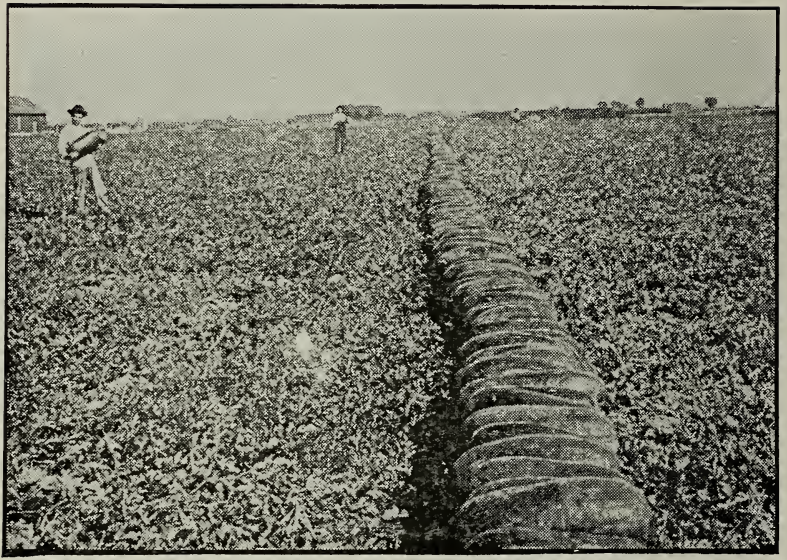

Above is a photograph of one of my seed fields of Burrell's Improved Kleckley Sweet Watermelon. The long row of melons are selected for stock seed. After my men select these melons and pile them in rows, I personally go over them and reject all not true to type. This very careful selection is done to keep my seed right. See price of this grade of seed next page -

\section{CULTURE.}

To successfully grow watermelons it is absolutely necessary to have good seed. Then select proper soil and give it proper cultivation and irrigation (if under irrigation) and if not prepare the land to drain off or retain the moisture, depending upon whether you get much or little rainfall, and the results are usually very good.

Select a well-drained sandy loam; new sod land is best; any good loamy soil which is well drained is good.

If under irrigation, run large furrows 8 feet apart and plant the hills well up on the border 8 to 10 feet apart. Be careful not to irrigate too often.

Watermelons are lovers of drouth, and the finest melons are grown under semi-arid conditions.

Plow deep and harrow well to make a fine seed bed. A liberal coat of stable manure disked in before plowing will increase the size and yield. If not under irrigation, plow the land in ridges by first throwing out a deadfurrow, then backfurrowing into the deadfurrow four or five furrows from each side, and after thoroughly harrowing, plant on the center of the ridge.

Do most of the cultivating with the harrow, setting the teeth straight and cultivating deep.

Keep a fine mulch on the surface and do not let any weeds grow.

Plant ten to twelve seeds to the hill and thin to one plant when they lave five to six leaves.

If you use commercial fertilizer mix it thoroughly with the soil around the hill, but do not leave any lumps under the hills where the first roots will reach it, or it will burn the roots and check the growth, if not kill the plant.

Do not plant on land where melons were grown before, even if four or five years before, if you have other good land. The vines remove something from the soil not readily replaced, and following crops usually produce deformed melons with black ends or shriveled ends, even from the best of seeds, while the same seed on adjoining land, where melons have not been grown before, will produce large melons of the finest quality.

Do not press on melons to see if they are ripe. This injures them and results in very poor melons. A slight thump with the finger if the sound rings clear and a high tone indicates a green melon; if a hollow, low tone, or rather a dead tone, the melon is ripe.

Usually the curl where the melon attaches to the vine dies when the melon is ripe. By a little practice you can tell by the color. A bright, growing color indicates a green melon: a dull green indicates ripeness.

The Improved Kleckley Sweet and New Chilian are the finest flavored melons an 1 fair shippers up to 150 to 175 miles.

The New Tom Watson and Alabama Sweet are the finest eating melons of the really good shippers

Thousands of the finest melon fields of the United States, from Florida to Oregon, from Texas to California are grown each year from my seeds. 


\section{Burrell's Improved Kleckley Sweet Watermelon

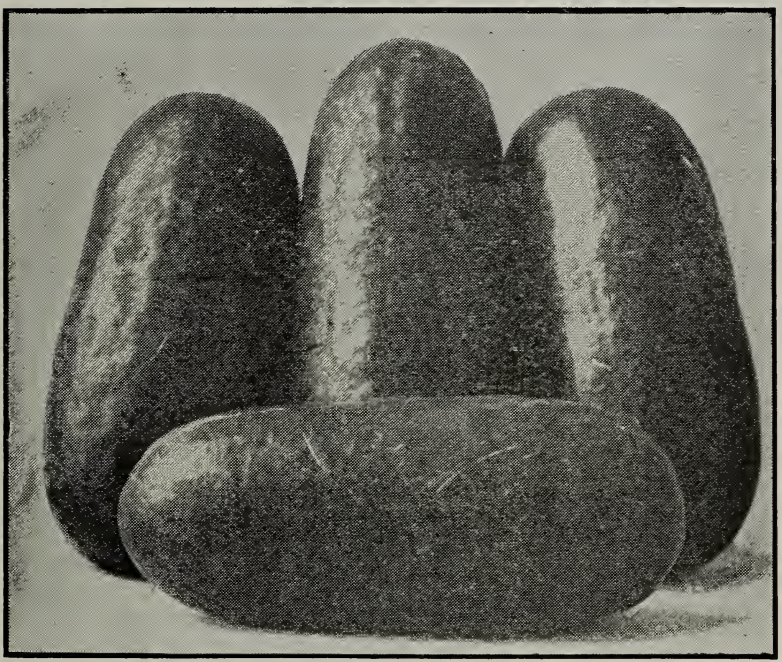

My strain of this melon is listed by some as the New Hard Shell Kleckley Sweet.

THE MOST DELICIOUS WATERMELON GROWX; VERY PRODCCTIVE AND OF ATTRACTIVE APPEARINCE.

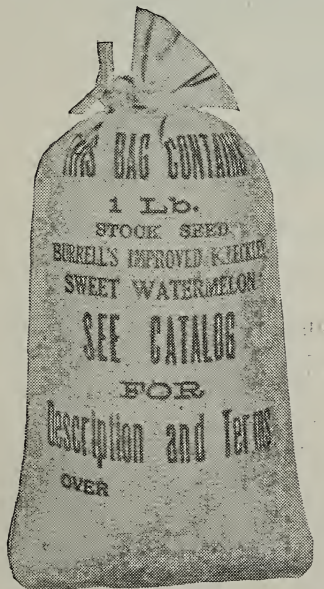

Again I offer this strain as the finest eating melon and the thousands of customers who continue to plant it speak volumes in its favor. Some report sales of as much as $\$ 200.00$ to $\$ 300.00$ per acre, which surely is rery good. As it grows with me it is not only the best eating melon, but a good shipper which holds first place on many markets.

The melon is oblong, ends square, color dark green, flesh deep red, stringless, solid and very sweet with but few white seeds set firmly near the rind. STOCK SEED BURTELL'S IMPROVED KLECKLEY SWEET WATERMELON.

This seed was cut from such melons as are pictured in the pile above. The stock seed melons would average 35 pounds each. Price-5c per pkt.; 15c pcr oz.; 55e per $1 / 4 \mathrm{lb}$.; $\$ 2.00$ per lb. Delivered by express.

For several years I hare been unable to supply the demand for stock seed of this variety, and last year I had to refuse about 1,000 orders for it, although I limited orders to five pounds each. I have cut about 100,000 of these finest melons, averaging $3 \overline{5}$ to 40 pounds.

want to supply some to all who wish this seed.

NO. 1 SEED BURRELI'S IMPROVED KLECKLEY SWEFT WATERMELON. Saved from desirable melons grown from same stock seed as above. Price-5e per pkt.; 10c per oz.; 35̃e per 1/4 lb.; \$1.25 per lb.; $\$ 1.10$ per lb. 10 lbs. and up. Delivered by express. 


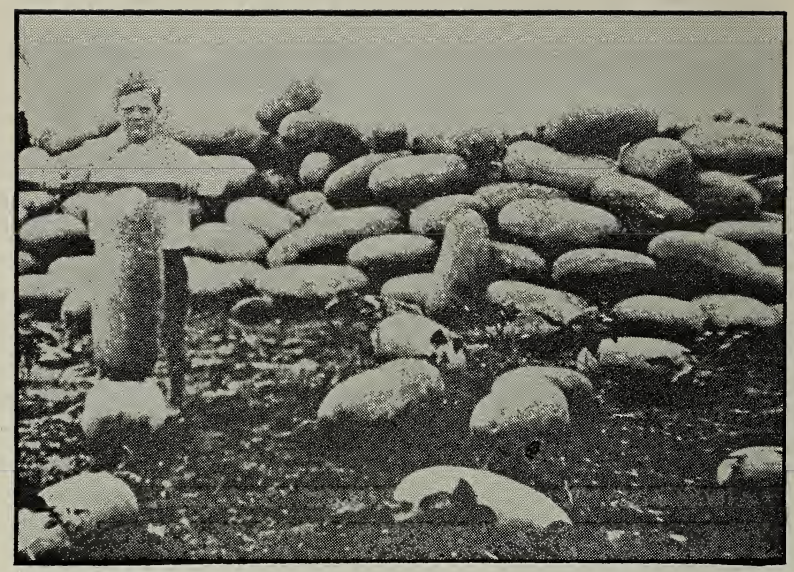

\section{The New Tom Watson Watermelon}

This large mottled green watermelon often weighs 50 to 60 pounds and averages on gond soil over 30 pounds. It has, within the past three years, won place among the very first as a market melon. The flesh is deep red and contains very few seeds, which are firmly bedded. It is the leader, taking into consideration size, shipping and eating quality. I have very carefully selected my stocks and have excellent seed to offer. Your orders will be placed where you should get excellent results if you buy this seed from mie.

Price-5c per pkt.; 10c per oz.; 50c per 1/4 lb.; $\$ 1.00$ per lb., 10 lbs. and up; $85 \mathrm{c}$ per pound. Put up in sealed packages.' See cut.

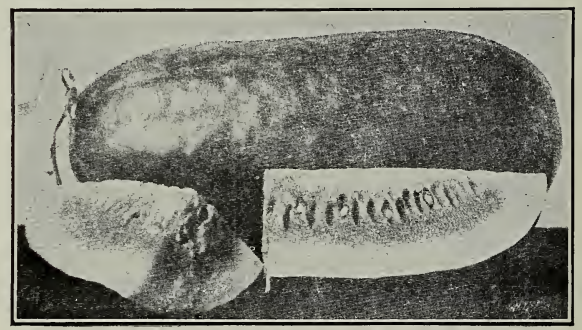

\section{Burrell's Select Alabama Sweet Watermelon}

This is a fine shipper. My seeds are planted extensively by many of the most successful Texas and other Southern melon growers.

The rind is dark green marked with still deeper green mottled stripe, and while thin, it is very tough, making the melon a first-class shipper. The flesh is bright red, fine-grained, sweet and luscious, entirely stringless and very firm. The seeds are white, slightly tipped with brown, and are firmly set in small cavities near the rind. The first car of watermelons shipped in 1912 in the United States was from my seed.

Many large Southern growers report that the finest crops grown in their districts were from my seeds.

My crops this year were as fine as I believe it is possible to grow. I saved especially for stock seed a considerable quantity of this seed from 35 to 40 -pound melons, and offer:

STOCK SEED BURRELL'S SFLECT ALABAMA SWEET from above described selection at: 5e per pkt.; 15e per oz.; 55e per 1/4 lb.; $\$ 2.00$ per lb.; $\$ 1.85$ per lb., 10 lbs. and up. Delivered by Express.

NO. 1 SEED BURRELL'S SELECT ALABAMA SWEET. Grown exclusively for seed and cut from fine melons. Price-5e per pkt.; 10c per oz.; 20c per 1/4 lb.; 60e per lb.; 55e per lb., $10 \mathrm{lbs}$. and up. Delivered by Express.

SOUTHERN ALABAMA SWEET. For those who wish Southern-grown Alabama Sweet, I have provided a large stock from some of the best Southern growers at 5c per pkt.; $10 \mathrm{c}$ per oz.; $20 \mathrm{c}$ per $1 / 4 \mathrm{lb}$.; 50c per lb.; 40c per lb., $10 \mathrm{lbs}$. and up. Delivered by Express.

I have a big sale on Southern-grown Alabama Sweet. 


\section{Watermelon---Cont'd}

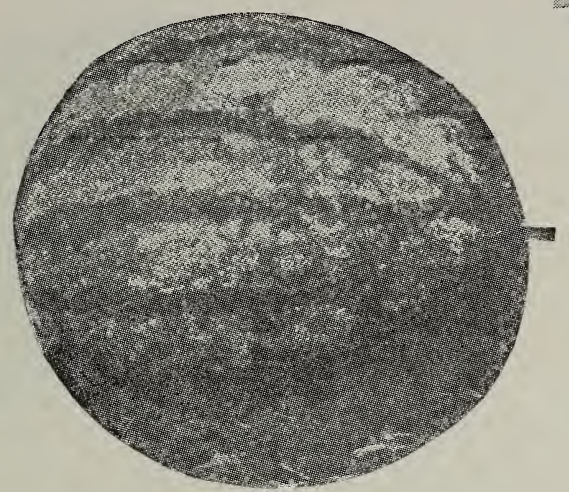

\section{Select New Chilian Watermelon}

This is the favorite melon in California and especially in the southern part, where large profits are made growing it.

My strain of this melon produces all white seeds. Some others produce mixed white and pale red seeds. Extreme care has been taken to make my strain the best possible and my crop the past year was as fine as could be desired.

The rind is thin and tough. The white seeds are set near the rind; heart bright red, stringless and of excellent quality.

Price-5e per pkt.; 10c per oz.; 20c per $1 / 4$ lb.; 75e per lb.; $\$ 7.00$ per 10 lbs.; 60c per lb., 40 lbs. and up. Delivered by Express.

FLORIDA FAVORITE WATERMELON. This is another variety on which my trade is very large, and I have increased my acreage to take care of this demand. My crop this year was very good. A beautiful melon with light and dark green exterior. Shape oblong; flesh bright crimson, crisp and deliciously sweet. It is only a few days later than the first early sorts and a good shipper. Price-5e per pkt.; 10c per oz.; 20c per $1 / 4$ lb.; 65c per lb.; 55c per lb, 10 lbs. and up. Delivered by Express.

\section{Halbert Honey Watermelon}

This melon is the same color and shape of my improved Kleckley Sweet, but is more tender. The melons split ahead of the knife when cut. The seeds, instead of being white, are a rather dull white with slightly brown tips.

It is of excellent quality and will be ordered extensively by those who know it best, which is the best recommendation that a melon can have.

Price-5c per pkt.; 10c per oz.; 30c per $1 / 4 \mathrm{lb}$.; $\$ 1.00$ per 1 b.; $85 \mathrm{c}$ per $1 \mathrm{lb.}$. to lbs. and up. Delivered by Express.

IeIVER'S WONDERFUL SUGAR. Owing to the very large demand for this variety I have increased my acreage and have several thousand pounds of seed to offer. It is not uncommon to grow crops of these long light an:1 dark green striped melons averaging 40 pounds. They are of very striking appearance and extra quality. Price-5e per pkt.; 10c per oz.; 20c per $1 / 4 \mathrm{lb}$; $65 \mathrm{c}$ per lb.; 55c per lb., $10 \mathrm{lbs}$. and up. Delivered by Express.

\section{Georgia Rattlesnake}

An excellent market variety; large and oblong; rind mottled and striped; a well-known shipping melon. Price-5e per pkt.; 10e per oz.; 20c per $1 / 4$ lb.; 65e per lb.; 55e per lb. in 10-lb. lots and up. 
This melon was originatcd by one of the leading melon growers in South Carolina and is an excellenc shipper. The outer rind is colored, as shown in cut, being dark green. The and are white and set in small carities, and the flesh is quite firm and red. It has a very tough rind and is one of the best shippers. Price - 5c per pkt.; 10c per oz.; $20 \mathrm{e}$ per $1 / 4$ lb.; 65e per lb., and up.

Girarcleau's Tri u m ph. This is an excellent shipping sort. It is early, the melons are large, dark green with indisdark green with indis-

solid and sweet. I'riee-5e per pkt.; $10 \mathrm{e}$ per oz.; $20 \mathrm{c}$ per $1 / 4$ lb.; $65 \mathrm{e}$ per lb.; 55e per lb. in 10-1b. lots and up.

Carolina Bradford. This is a large, long, dark green melon, dimly marked with lighter green stripes. The rind is tough, making it a good shipper. Price-5e per pkt.; $10 \mathrm{c}$ per oz.; $20 \mathrm{c}$ per $1 / 1 \mathrm{lb}$.; 65e per lb.; 55e per lb. in 10-lb. lots and np.

Black Spanish. Round, dark green, scarlet flesh, black seeds; not a large melon, but of good flavor. Priee-5e per pkt.; 10e per oz.; 20c per $1 / 4$ lb.; 65e per lb.; 55c per $1 \mathrm{~b}$. in $10-\mathrm{lb}$. lots and up.

Cuban Queen. An old, weil-known variety that is a very good shipper and grows to an enormous size. It is a heavy yielder. The rind is marked, light and dark green; flesh bright red, very solid, crisp and sugary; shape oblong. Price-5e per pkt.; 10e per oz.; 20c per $1 / 4 \mathrm{lb}$.; $65 \mathrm{c}$ per $1 \mathrm{~b}$.; 55e per $1 \mathrm{~b}$. in $10-\mathrm{lb}$. lots and up.

Cole's Early. This is one of the earliest melons and a very hardy sure cropper; medium size, slightly oblong shaped; rind green, striped with lighter shades; flesh dark red. Price-5c per pkt.; 10c per oz.; 20c per $1 / 4 \mathrm{lb}$.; 65e per $1 \mathrm{~b}$.; $55 \mathrm{c}$ per $\mathrm{lb}$. in $10-1 \mathrm{~b}$. lots and up.

Dixie. One of the best. A cross between the Kolb's Gem and Mountain Sweet, possessing the best qualities of both. Rind dark green, striped with light green: shape much longer than Kolb's Gem; very large and of good flavor. Price-5e per plkt.; 10 e per oz.; 20e per $1 / 4 \mathrm{lb}$.; 65 e per lb.; 55c per $1 \mathrm{lb}$, in $10-1 \mathrm{~b}$. Lots and up.

Ice Cream. An early variety of good flavor. One of the best to grow in the North, and being so good, it is one that should be in every garden. Price-5c per pki; 10c per oz.; $20 \mathrm{c}$ per $1 / 4 \mathrm{lb}$; 65c per $1 \mathrm{~b}$; $55 \mathrm{c}$ per $1 \mathrm{~b}$. in 10-lb. lots and up.

Mountain Sweet. An old variety but still good. Fruits long and dark green. Price-5c per pkt.; 10c oz.; 20c per $1 / 4$ lb.; 65e per lb.: 55e per 1b. in 10-lb. lots and up.

Early Fordhook. A very popular sort; medium size; flesh red and sweet; color a mottled gray. Price-5e per pkt.; 10c per oz.; 20c per $1 / 4 \mathbf{l b . ;} 65$ c per $1 \mathrm{~b} . ; 55 \mathrm{c}$ ver $1 \mathrm{~b}$. in $10-1 \mathrm{~b}$. lots.

Gray Monarch. One of the largest melons, often weighing 60 to 70 pounds. Rind mottled gray; shape long; flesh erimson, of a good flavor and a good shipper. Price--5e per pkt.; $10 \mathrm{e}$ per oz.; 20e per $1 / 4 \mathrm{lb}$.; $65 \mathrm{e}$ per lb.; $55 \mathrm{c}$ per $1 \mathrm{lb}$. in $10-\mathrm{lb}$. lots and up.

Phinney's Farly. Another very early melon; hardy; a sure cropper; extensively cultivated in the North. Price-5e per pkt.; 10c per oz.; 20c per $1 / 4 \mathrm{lb}$.; $65 \mathrm{c}$ per $1 \mathrm{~b}$.; 55c per lb. in 10-lb. lots and up.

Mountain Sprout. Large, long. dark green, marbled with lighter shades. Price-5e per pkt.; 10c per oz.; $20 \mathrm{c}$ per $1 / 4 \mathrm{lb}$.; $65 \mathrm{c}$ per $1 \mathrm{~b}$.; $55 \mathrm{c}$ per $\mathrm{lb}$. in 10-lb. lots and up.

Hungarian Honey. A new variety brought from Hungary a few years ago. Round, uniform size; 10 to 15 pounds; dark green; thin rind; flesh red and yery sweet. Price-5e per pkt.; $10 \mathrm{c}$ per $0 z$; $20 \mathrm{c}$ per $1 / 4 \mathrm{lb}$.; $65 \mathrm{c}$ per lb.; 55e per lb. in 10-lb. lots and up.

Mammoth Iron Clad. Oblong; dark green, mottled with lighter shades; flesh bright red, firm, sugary; size very large, often weighing from 60 to 70 pounds. A good shipper. Price-5e per pkt.; 10c per oz.; 20c per $1 / 1$ lb.; 65c per $1 \mathrm{~b}$.

Add $8 \mathrm{c}$ per $1 \mathrm{~b}$. to all varieties of watermelons if by mail.

Kentucky Wonder. A new red-seeded variety; oblong; rind dark green with lighter stripes. Flesh a bright red, sugary and firm; it is never mealy; very good. Price-5e per pkt.; 10c per oz.; 20c per 1/4 lb.; 65c per lb.; 55c per $1 b$. in 10-lb. lots and up.

Kolb's Gem. More largely grown in the South than any other melon. An extra shipper; round, large, good quality; color dark green, mottled. extra shipper; round, large, good quality ; color dark green, mottled. 10-lb. lots and up.

In addition, I offer the following varieties at the uniform price of: 5e per pkt.; 10c per oz.; 20c per $1 / 4 \mathrm{lb}$.; 65e per $1 \mathrm{~b}$.; 55c per $1 \mathrm{lb}$. in 10 -lb. lots and up: Black Diamnnd, Boss, Duke Jones, Light Icing, Round Striped Gipsy, Sweetheart and Vick's Early. 


\section{O N I O N}

In onion culture, thorough preparation of the ground, careful sowing and the best of after culture, though essential for a full yield, will arail nothing unless seed of the best quality be used. Given the same care and conditions, the product from two lots of onion seed of the same variety but of different quality may be so unequal in the quantity of merchantable onions that it would be more profitable to use the good seed though it cost twenty times as much as the other The seed I offer is the best obtainable. Although onions are often raised from sets and from division, by far the best and cheapest mode of production is from seed. The facility with which seed is sown and the superior bulbs it produces, recommend it for general use.

\section{HOW TO RAISE ONIONS}

THE SOrL. A crop of onions can be grown on any soil which will produce a full crop of corn, but on a stiff clay, very light sand or gravel, or on some muck or swamp lands, neither a large nor a rery profitable crop can be grown. I prefer a rich loam with a slight mixture of clay. This is much better if it has been cultivated with hoed crops, kept clean from weeds and well manured for two years previous, because if a sufficient quantity of manure to raise an ordinary soil to a proper degree of fertility is applied at once, it is likely to make the onions soft. The same result will follow if we sow on rank mucky ground or on that which is too wet.

MANCRING. There is no erop in which a liberal use of manure is more essential than in this, and it should be of the best quality, well fermented and shoveled over at least twice during the previous summer to kill wced seeds. If rank, fresh manure is used, it is liable to result in soft bulbs with many scallions. Of the commercial manures, any of the high-grade, complete fertilizers are good for ordinary soils and even very rich soils are trequently greatly benefited by fine ground bone, and mucky ones by a liberal dressing of wood ashes.

PREPARATION. Remove all refuse of previous erops in time to complete the work before the ground freezes up and spread the composted manure evenly at the rate of alout twenty tons to the acre. This should first be disced in and then the ground ploughed a moderate depth, taking a narrow furrow in order to thoroughly mix the manure with the soil. Carefully avoid tramping on the ground during the winter. Disc thoroughly as early in the spring as it can be worked, after which the entire surface shoula be made fine and level with a smoothing harrow. It is imsurface should be made fine and level with a smoothing harrow. It is im-
possible to cultivate the crop economically unless the rows are perfectly straight.

SOWING THE SFED. This should be done as soon as the ground can be made ready and can be done best by a hand seed drill. This should be carefully adjusted to sow the desired quantity of seed about one-half inch deep. The quantity needed will vary with the soil, the seed used and the kind of onions desired. Thin seeding gives much larger onions than thick seeding. Four or fire pounds per acre is the usual quantity needed to grow large onions. I use a drill with a roller attached, but if the drill has none, the ground should be well rolled with a light hand roller immediately after the seed is planted.

CILTIVATION. Give the onions the first hoeing, just skimming the ground between the rows, as soon as they can be seen in the row. Hoe again in a few days, this time close up to the plants, after which weeding must be begun. This operation requires to be carefully and thoroughly done. The weeder must work on his knees astride the row, stirring the earth around the plants, in order to destroy any weeds that have just started. At this weeding or the next, according to the size of the plants, the rows should be thinned, leaving from eight to twelve plants to the foot. In ter days or two weeks they will require another hoeing and weeding similar to the last. and two weeks later give them still another hoeing and if necessary another weeding. If the work has been thoroughly done at the proper time, the crop will not require further care until ready to gather.

GATHERING. As soon as the tops die and fall, the bulbs should be gathered into windrows. If the weather is fine they will need no attention Thile curing, but if it is not they will need to be stirred by simply moring them slightly along the row. Cut off the tops when perfectly dry, about half an inch from the bulb and then after a few days of bright weather the onions will be fit to store for winter.

It will not do to store onions in large piles or masses, particularly in warm weathel, or if they are the least moist, but if perfectly dry when gathered and they are spread not to exceed two feet in depth, they can be kept in fine condition till spring. Any arrangement will answer that wil keep them dry and at a nniform temperature of about 32 degrees Farenheit, or they may be kept frozen, care being taken not to disturb them. They should be thawed gradually. Repeated freezing and thawing will spoil them.

If bothered with thrip (a small insect which sometimes attacks onions doing great damage) spray with a tobacco emulsion. Three sprayings will usually completely control them.

Very early onions are grown by the transplanting method, the seed being sown in firmes or beds and the small onions transplanted when the size of sniall lead pencils to the field rows. 


\section{ONIONS---Continued}

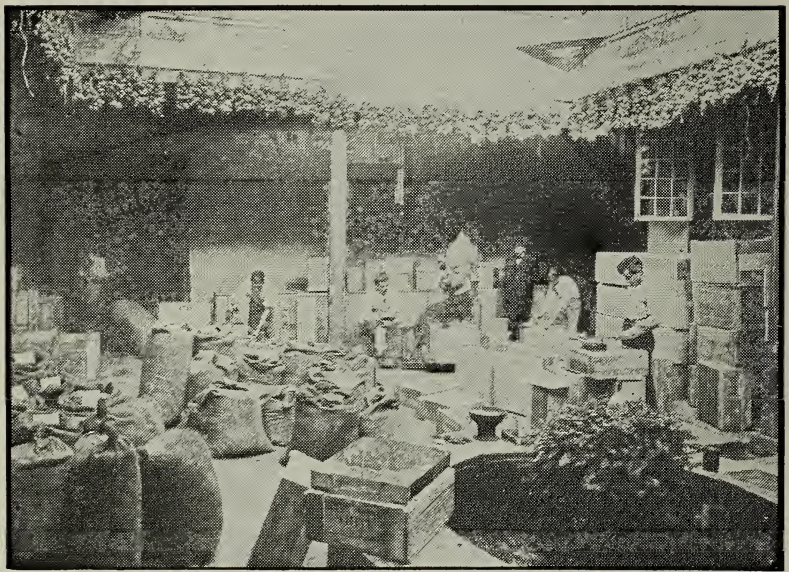

Packing Bermuda Onion Seed in Tin-lined Cases Ready for Shipment, Teneriffe.

I import large quantities of Bermuda Onion Seed and supply many of the largest growers in Texas and the Imperial Valley of California.

I have already sold over 12,000 pounds of seeds to the large Texas growers for delivery crop 1913.

I want your orders. Write for terms, stating how much seed you wish. The varieties are:

\section{White (Yellow) Bermuda}

\section{Crystal Wax \\ Red Bermuda}

These seeds are shipped from Teneriffe in July and delivery can usually be made by express from August 20th to September 1st. My prices will be on the best seed.

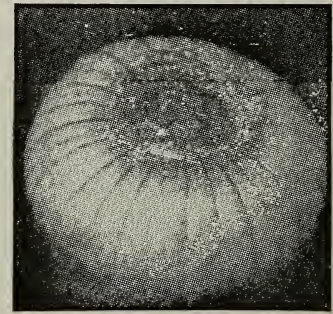

Crystal Wax.

The crop of Bermuda Onion Seed was short the past year and I am sold out except a small amount of the following:

\section{Red Bermuda}

Genuine Teneriffe grown. This is a pale red, very mild and tender onion, of zood quality; does best in the South; would suggest only light p'anting in the Middle and Northern states.

Price-5e per pkt.; 20c per oz.; 70c per $1 / 4 \mathrm{lb}$.; $\$ 2.65$ per $1 \mathrm{lb}$.; $\$ 2.50$ per $\mathrm{lb}$. in 10-lb. lots.

Crystal Wax European Grown. See next page. 


\section{ONIONS----Continued}

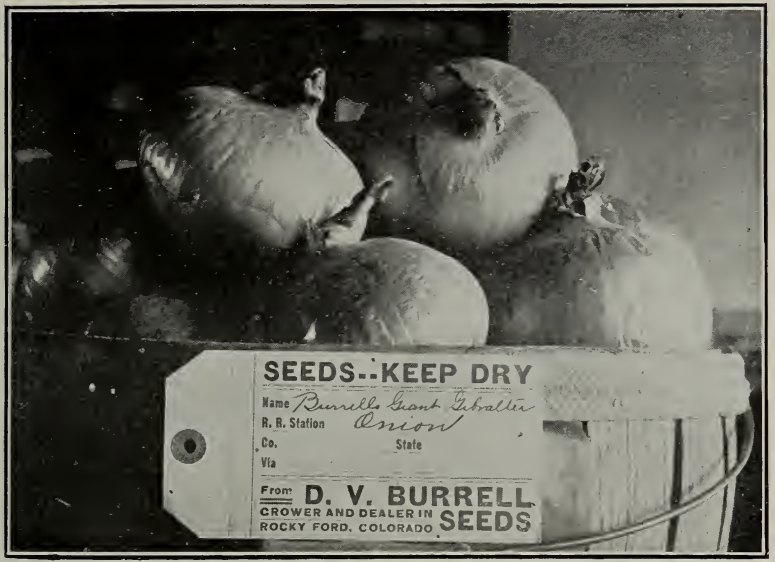

\section{Burrell's Giant Gibraltar Onion}

\section{LARGEST ONION. VERY MILD. LARGEST YIELDER. VERY SHORT CROP.}

In the above illustration is shown a photograph of a half bushel of these onions.

It is a beautiful onion with thin skin of a light straw color. The flesh is white, mild and sweet. It makes a large, quick growth, is later and larger than the Prizetaker. Grown as a Spanish onion and crated, it is excellent for the fall and winter trade. It is a fine variety for display on vegetable stands, as it attracts much attention.

Price-5e per pkt.; 20 c per oz.; $65 \mathrm{c}$ per $1 / 4 \mathrm{lb}$.; $\$ 2.50$ per $1 \mathrm{~b}$.; $\$ 2.40$ per lb. in 10-lb. lots and up.

$$
\text { Add } 8 \mathrm{c} \text { per pound if by mail. }
$$

PRIZETAKER. Quite like the above in color, but different in shape, being nearly a perfect globe. Hundreds of acres of this sort are grown in single districts in Texas. This variety of recent introduction annually grows in favor. It is very productive, attractive in appearance and quality, being mild in flavor as the Imported Spanish onions of our grocers. Can be grown successfully in any locality where other onions are produced. The color is a bright straw, and it always grows to a uniform shape. Having a small neck, stiff necks are almost unknown. We call attention to the fact: Our seed is the choicest American grown and not Imported Spanish King, as sold by some dealers at low prices under the name of Prizetaker.

Prices-5c per pkt.; 15c per oz.; 50c per 1/4 lb.; \$1.90 per lb.; $10 \mathrm{lbs}$. and up, $\$ 1.80$ per $1 \mathrm{~b}$.

\section{CRYSTAL WAX---European Grown}

I have been importing this seed for several years, and the results which have been obtained have been very satisfactory with Southern planters who have tested it in comparison with Teneriffe-grown seed. It is grown under practically the same climatic conditions as the Teneriffe seed and only one crop from the genuine Teneriffe seed.

This year Teneriffe-grown Crystal Wax is not obtainable, as very little of the seed was produced, and the seed which I am offering is very nearly all the Crystal Wax seed there is in the whole of the United States and Europe.

This is a very mild, flat, white onion. See cut previous page.

Price-10c per pkt.; 50c per oz.; $\$ 1.50$ per $1 / 4 \mathrm{lb}$.; $\$ 5.00$ per $\mathrm{lb}$. 


\section{ONIONS---continued}

soed crower

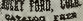

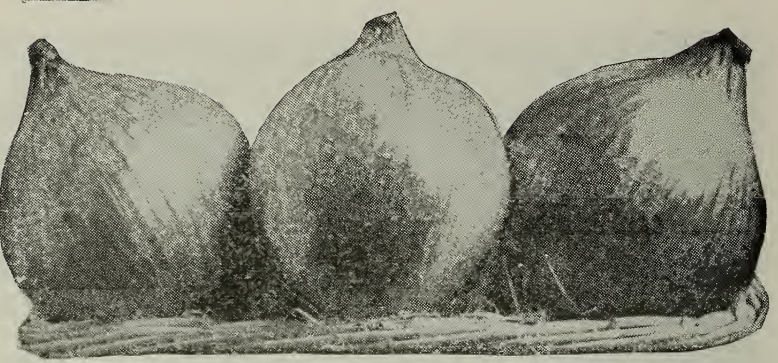

\section{Ailsa Craig Onion}

This very large, nearly round, straw-colored onion is one of the largest grown. It is in great demand in the markets wherever offered.

By planting the seed very early in frames and transplanting to the open ground as soon as the ground will do to work in the spring, at which time the plants should be the size of a large lead pencil, very large crops can be produced.

This onion is very mild and any district where onions grow well can establish a paying industry by growing these and marketing them crated.

A very fine exhibition onion. Grow some of these in your garden, either for market or home use, and you will be well pleased.

Price-5e per pkt.; 20c per ez.; 65c per $1 / 4 \mathrm{lb}$.; $\$ 2.50$ per $1 \mathrm{~b} . ; \$ 2.40$ per lb. in 10-lb. lots and up.

\section{Mamoth Silver King}

Of attractive shape, with silver-white skin and flesh of a most agreeable, mild flavor. It matures quite early and reaches a much larger size than any other of the flat varieties, frequently measuring 20 inches in circumference, and weighing from 3 to 5 pounds when well grown. Must be sown thinly to produce large onions. This is a fine sort to grow for exhibition purposes.

Price-5c per pkt.; $15 \mathrm{c}$ per oz.; 40 c per $1 / 4$ lb.; $\$ 1.40$ per lb.; $\$ 1.35$ per lb. in 10-lb. lots and up.

\section{Giant White Italian Tripoli}

El Paso or Large Mexican. Of large size and most beautiful form with fine white skin. The first season it will grow an onion from one to one and a half pounds. Price-5c per pkt.; 15c per oz.; $40 \mathrm{c}$ per $1 / 4 \mathrm{lb}$; $\$ 1.40$ per lb.; $\$ 1.35$ per $1 \mathrm{~b}$. in $10-1 b$. lots and up.

\section{Market Gardeners' Bunching Onion}

This is the most valuable sort to plant in midsummer rather thickly and leave in the ground over winter for early spring bunching onions.

They are ready very early and are of excellent quality and appearance. The long white roots when cleaned and bunched get the best of the market.

Many growers plant fifty to one hundred pounds at a time.

The past season the crop of seed was very short.

Price-5e per pkt.; 15c per oz.; $40 \mathrm{c}$ per $1 / 4 \mathrm{lb}$.; $\$ 1.40$ per lb.; $\$ 1.35$ per lb. in 10-lb. lots and up. 


\section{ONIONS----continued}

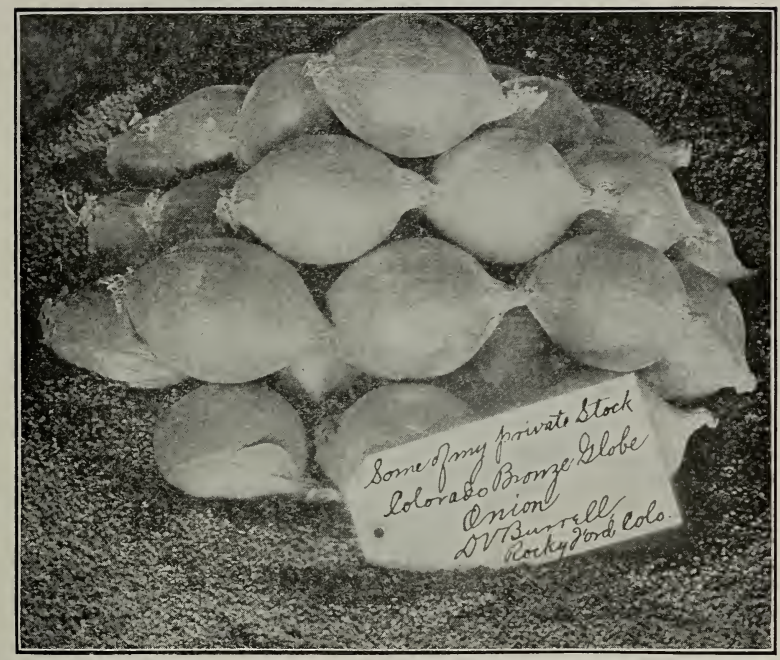

\section{Burrell's Private Stock, Colorado Bronze Globe Onion}

This is a special selection from the Southport Yellow Globe. It is a great yielder and one of the best to store for spring trade, as it is an excellent keeper. The bulbs are a bronze color, shaped as shown in cut, of good size.

Price-5c per pkt.; 15e per oz.; 55e per 1/4 lb.; $\$ 2.00$ per lb.; $\$ 1.90$ per 1b. in 10-1b. lots and up.

\section{Large Red Wethersfield}

It is fine-grained and strong in flavor. Very productive and an excellent keeper. Immense crops of this are grown for shipment, and it certainly is one of the very best sorts for market.

Price-5c pe: pkt.; $15 \mathrm{c}$ per oz.; $40 \mathrm{c}$ per $1 / 4 \mathrm{lb}$.; $\$ 1.40$ per lb.; $\$ 1.35$ per $\mathrm{lb}$. in 10-lb. lots and up.

\section{Australian Brown Onion}

A valuable, early variety of meảium size, hard and solid, attractive for market, both as to form and appearance. Never make any stiff necks or scullions. It has the reputation of keeping indefinitely. Color of the skin is a clear amber brown.

Price-5e per pkt.; $15 \mathrm{c}$ per oz.; $40 \mathrm{c}$ per $1 / 4 \mathrm{lb}$.; $\$ 1.40$ per lb.; $\$ 1.35$ per lb. in 10-lb. lots and up.

\section{White Portugal or Silver Skin}

A large, flat, white nnion of mild and pleasant flavor; hard and finegrained and a good lieeper. More extensively sown for sets than any other variety and is also largely grown for pickling.

Price-5c per pkt.; 15e per oz.; 50c per $1 / 4 \mathrm{lb}$.; $\$ 1.90$ per $1 \mathrm{lb}$.; $\$ 1.85$ per $\mathbf{l b}$. in 10-lb. lots and up. 


\section{ONIONS----continued}

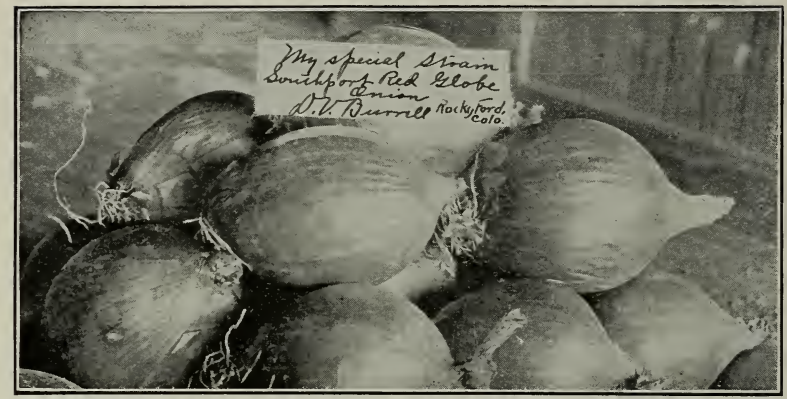

\section{Burrell's Special Stock, Southport Red Globe Onion}

The above is a photograph of some of my onions. The type is right and the quality of the best to be had. It matures nearly as early as the flat sorts, grows to a large size and is very mild and tender. It is a GOOD KEEPER and considered ONE OF THE BEST RED ONIONS. Add $8 \mathrm{c}$ per pound if by mail.

Price-5c per pkt.; $15 c$ per oz.; 50c per $1 / 4 \mathrm{lb}$.; $\$ 1.90$ per $1 \mathrm{lb}$; $\$ 1.85$ per $1 \mathrm{~b}$. in 10-lb. lots and up.

\section{Southport Yellow Globe}

Shape same as Colorado Bronze Globe. (See previous page). This variety is well known and planted very extensively in the East. It is a little later than the Globe Danver, a very heavy yielder and a sure cropper.

Price-5c per pkt.; 15c per oz.; 40c per 1/4 lb.; $\$ 1.50$ per lb.; $\$ 1.45$ per $\mathrm{lb}$. in 10-lb. lots and up.

\section{Southport White Globe}

Same shape as above; color a clear white. The best keeper of the white sorts. Produces a heavy crop of excellent quality and always sells for top prices on the markets.

Price-5e per pkt.; 20c per oz.; 60c per $1 / 4 \mathrm{lb}$.; $\$ 2.25$ per lb.; $\$ 2.10$ per $1 b$. in 10-lb. lots and up.

\section{Onion Seeds for Sets}

Bottom sets are produced from seed by sowing in broad drills early in the spring at the rate of 60 to 70 pounds of seed per acre.

If y u wish to grow sets, write for special prices on seeds for sets, stating the variety wanted and number of pounds, and I will make you the best possible prices. 


\section{ONIONS---Continued}
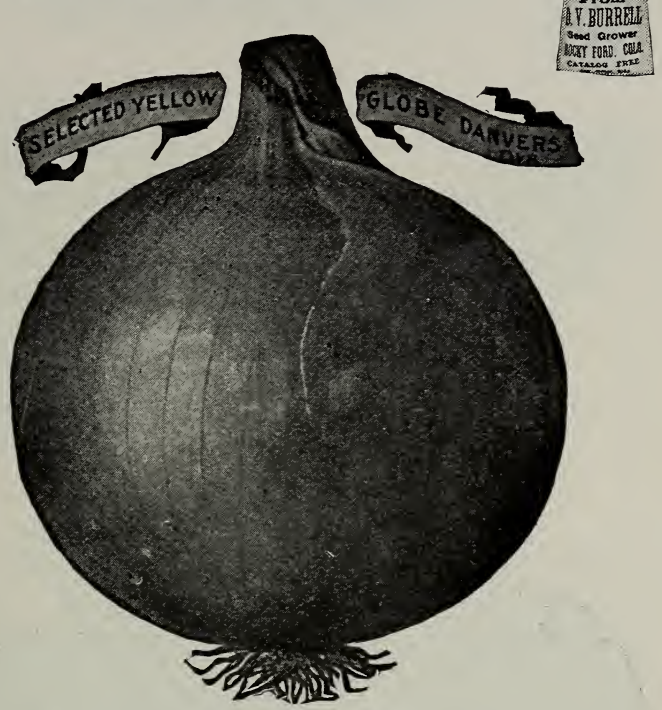

Yellow Globe Danver Onion

Undoubtedly the best known and most popular of all onions; the earliest yellow variety; is entirely free from stiff necks; globular in shape, has a small top. It is the most productive, producing as high as 1,000 bushels per acre, and will average on good soil with proper culture, 600 to 700 bushels. It is a splendid keeper, well rounded, a very small amount of waste. This seed has proven a sreat favorite with my customers who plant thousands of pounds. Price -5e per pkt.; 15e per oz.; 40c per 1/4 lb.; $\$ 1.25$ per lb.; $\$ 1.20$ per $1 \mathrm{lb}$. in $10-1 \mathrm{~b}$. lots and up.

YELLOW FLAT DANVER. My strain of this well-known variety is of the very best, producing a uniform crop, which matures just at the right time for storing for winter. This seed sown thick (60 lbs. to the acre) produces very fine bottom sets. It is free from stiff necks, has a small top and is very productive. Price-5e per pkt.; 15 e per oz.; 40 e per $1 / 4$ lb.; $\$ 1.25$ per $1 \mathrm{lb}$.; $\$ 1.20$ per $\mathrm{lb}$, in $10-\mathrm{lb}$. lots and up.

WHITE QUEEN. Very early, small pickling onion; the seed is also planted thick for bunching onions, and at the rate of 60 to 70 pounds per acre for sets. Price-5e per pkt.; 10e per oz.; 30e per $1 / 4 \mathrm{lb}$.; $\$ 1.10$ per lb.; $\$ 1.00$ per $1 \mathrm{~b}$. in $10-1 b$. lots.

WHITE PEARI. Quite similar to White Queen. Extensively planted for sets. Price-5e per pkt.; $10 \mathrm{c}$ per oz.; $30 \mathrm{c}$ per $1 / 4 \mathrm{lb}$.; $\$ 1.10$ per lb.; $\$ 1.00$ per $\mathrm{lb}$. in 10-lb. lots.

WHITE BARLETT. When matured, the tops die down, leaving beautiful and perfect little bulbs. The color is pure white, flavor mild and delicate, perfectly adapted for pickling and table use, and makes a pretty bunch onion, especially if grown by the transplanting method. Price-5c per pkt.; 15e per oz.; $45 \mathrm{c}$ per $1 / 4 \mathrm{lb}$; $\$ 1.50$ per $1 \mathrm{~b}$.; $\$ 1.40$ per $1 \mathrm{~b}$. in $10-\mathrm{lb}$. lots and u!p.

Add $8 \mathrm{ce}$ per pound to price on all varieties of onions if by mail.

\section{Okra}

Add $8 \mathrm{c}$ per pound if by mail.

Extra Early Dwarf (Green Pods), Very early and productive. Price-5e per oz.; 15e per $1 / 4 \mathrm{lb}$.; 40c per ib.; $\$ 3.00$ per $10 \mathrm{lbs}$.

Early Dwarf White (White Pods). Pods extra long and when fully matured, measuring a foot in length and very thick and fleshy; early and prolific. Fine for soups. Price-5e per oz.; 15e per $1 / 4 \mathrm{lb}$.; $40 \mathrm{e}$ per lb.; $\$ 3.00$ per $10 \mathrm{lbs}$.

White Velvet. A great improvement over older varieties; pods larger, white, very smooth, a more abundant bearer; superior quality. Price5e per oz.; $15 \mathrm{c}$ per $1 / 4 \mathrm{lb}$.; $45 \mathrm{c}$ per $\mathrm{lb}$.; $\$ 33.50$ per $10 \mathrm{lbs}$.

Perkins' Perfection Mammoth Green Pod. This seed is grown for me by Mr. Perkins, who originated it the stock is of the best to be had. The most productive. Pods very large. Extremely early, tender and preferred by canners as well as growers for market. Price-5e per pkt.; 20c per $1 / 4$ lb.; 60c per lb.; 55c per $1 \mathrm{~b}$. in $10-\mathrm{lb}$. lots. 


\section{PUMPKINS}

Pumpkins are very easily grown, as the seeds are large, the young plants come up strong and the crop is less particular as to the quality of soil compared with melons or cucumbers.

They do best when planted alone with rows about 5 feet apart for the small sorts and $S$ feet apart for the large sort. Plant 10 to 12 seeds to the hill, and when the plants have five of six leaves thin to two, and when runners are 12 to 18 inches long, thin to one by cutting off the other at the surface. This gives protection against insects. Cultivate thoroughly and keep free of weeds.

Good results are obtained by planting a hill every 15 to 20 feet each way in the cornfield, but not compared with above plan.

For insects, take some well-slaked lime and mix with three times as much fine dust, stir into this 2 or 3 tablespoonfuls of turpentine to each pailful and dust the plants; also put a small amount of this around the root of each plant.

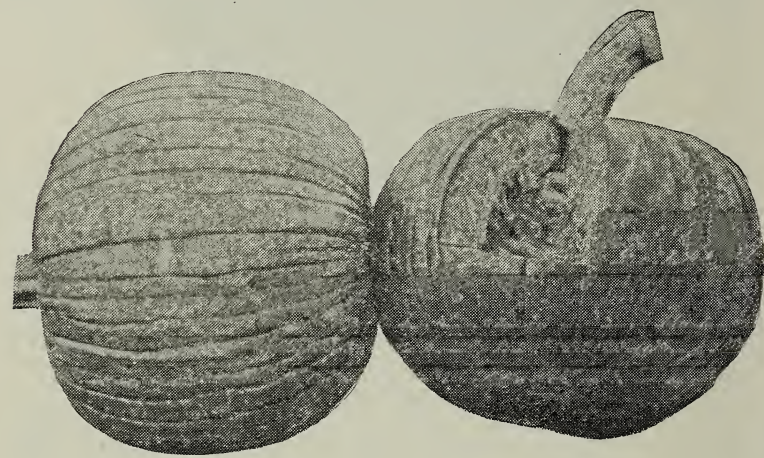

\section{Small Sugar or New England Pie}

An excellent sort; shape as shown above. Flesh very deep orange. Fruits 8 to 10 inches through. The quality is of the best; none better for pies. Price-5e per pkt.; $10 \mathrm{c}$ per oz.; $20 \mathrm{e}$ per $1 / 4 \mathrm{lb}$.; $65 \mathrm{c}$ per $1 \mathrm{~b}$. ; $60 \mathrm{c}$ per lb. in 10-lb. lots.

Large Sweet Cheese. Flat, creamy yellow, well known; one of the stancard sorts. Price-5e per oz.; 15e per $1 / 1 / 4$ lb.; 50e per lb.; 40c per lb. in 10-lb. lots and up.

Connecticut Field. 'The well-known, large, yellow field pumpkin. Price$15 \mathrm{c}$ per $1 / 2 \mathrm{lb}$.; 25e per 1b.; 20c per $\mathrm{lb}$. in 10-lb. lots and up.

Michigan Mammoth. Similar to above, only extremely large. Price-5e per oz.; 15e per $1 / 4$ lb.; 40 c per $1 b$.; 35c per $1 b$. in $10-1 b$. lots.

King of Mammoths. This is the exhibition pumpkin for the fair, often weighing 150 to 200 pounds. In quality none are better for pies, and except where the black squash bug is bad, it always yields heavily. Outer color light creamy red; meat deep orange red. Note.-Often the seed from a big specimen is sold at $5 \mathrm{c}$ per seed to those who do not know it by name. Price-5e per pkt.; 10c per oz.; 30c per 1/4 lb.; $\$ 1.00$ per lb.; 90c per lb. in 10-lb. lots and up.

Add $8 \mathrm{c}$ yer pound, if by mail. 


\section{PUMPKINS----Continued

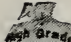 \\ SEEDS 1. Trose ond onower rad onow

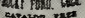

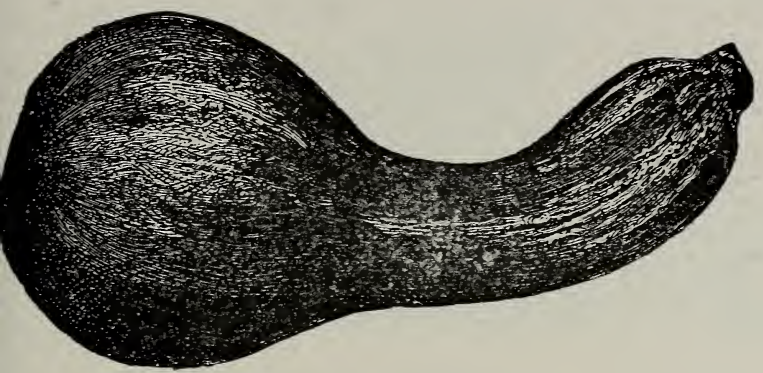

\section{Japanese Pie}

This is one of the finest rarieties of pumpkins. Color of rind, dark slate green with very slightly lighter mottled stripes. The neck is very large in proportion to the size of the bowl and in it the meat is solid. In quality none can surpass it. Color of meat, very deep orange red, givins the pies that richest pumplin color as well as flavor. It is a heary yielder and where squash bugs bother the rines it succeeds better than any other sort. The seeds are peculiarly marked, as if covered with Japanese characters, hence its name.

Price-5c per pkt.; 10c per oz.; $25 \mathrm{c}$ per $1 / 4 \mathrm{lb}$.; $80 \mathrm{c}$ per $1 \mathrm{~b} . ;$ :0c per $\mathrm{lb}$. in 10-lb. lots.

\section{Green Striped Cushaw}

This variety is shaped same as above, but larger and lighter colored. The rind is a pale slate green, striped with a darker green. The flesh is light yellow. The large neck is solid flesh of excellent quality.

It is one of the best for pies or to bake as are squashes.

For several years there has not been sufficient of this seed to supply the demand.

Price-5e per pkt.; 10c per oz.; 25e per $1 / 4 \mathrm{lb}$.; 80c per $1 \mathrm{~b}$; $70 \mathrm{c}$ per $1 \mathrm{~b}$. in 10-lb. lots.

\section{Livingston's Pie}

This very fine variety is nearly round, $\&$ to 10 inches through. The rind is light yellow, corered with a fine netting. The flesh a deep orange. fine-grained and of excellent quality. One of the best for pies.

Price-5e per pkt.; 10c per oz.; 20c per $1 / 4 \mathrm{lb}$.; 65e per $1 \mathrm{~b}$.; 60c per lb. in 10-lb. lots.

\section{PARSLEY}

Champion Moss Curled. Is a prize winner English variety, in appearance like a tuft of finely curled moss, and of a rich deep green color. It is slow to run to seed and very hardy; of easiest growth; a few seeds sown in onion rows use no space; grows in window boxes. Extra fine for garnishing and culinary purposes. Price-5c per pkt.; 10c per oz.; 35c per $1 / 4 \mathrm{lb}$.; $\$ 1.20$ per $\mathrm{lb}$.; $\$ 1.00$ per $\mathrm{lb}$. in $10-\mathrm{lb}$. lots.

Fine Double Curled. A standard variety: plants bear an abundance of finely curled leares: very ornamental. Price-5e per pkt.; 10c per oz.; $35 c$ per $1 / 4$ lb.; $\$ 1.20$ per $1 b . ; \$ 1.00$ per $1 b$. in $10-1 b$. lots.

Emerald Curled. Extra fine; the leaves are very finely curled and of a deep emerald green color; very easy grower and none finer. Price-5c per pkt.; $10 \mathrm{c}$ per oz.; $35 \mathrm{c}$ per $1 / 4 \mathrm{lb}$.; $\$ 1.20$ per $1 \mathrm{~b}$.; $\$ 1.00$ per $1 \mathrm{lb}$. in $10-1 b$. lots. 


\section{PEAS}

Very early peas require a light and warm soil; too heavy soil will cause them to rot before sprouting.

Later peas will stand a heavier soil, but a sticliy, heavy soil is not desirable. For earliest, sow as soon as possible in the spring on soil which bas becn prepared in the fall kefore and only requires a thorough discing or cultivating and leveling before planting.

All varieties should be sown comparatively early. By planting different varieties, sonle early, soine medium and some late, a succession may be had.

Plant only about 1 inch deep. Late varieties may be planted in furrows 4 or 5 inches deep, covering only an inch at first and later when the peas are 8 or 10 inches high, cultivate the earth toward the plants, leveling the furrows.

Rows may be 2 feet to 30 inches apart; plant 60 to 90 pounds of seed per acte; 1 pint to 100 feet of drill.

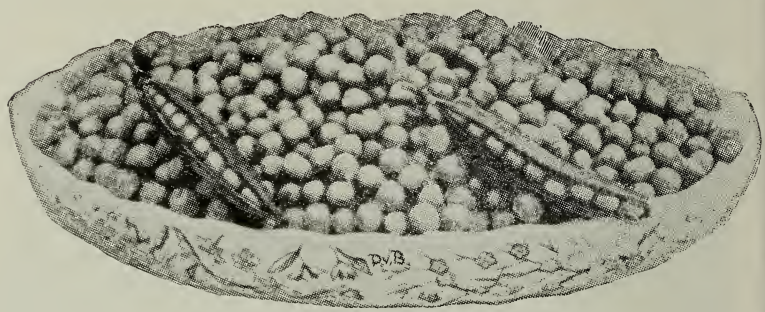

The pea crop is again very short. Order early while the supply of the different varieties is complete.

Add $8 \mathrm{c}$ per pint, $15 \mathrm{c}$ per quart, if by mail.

\section{ALASKA}

The very best early green seeded variety. The dark green color of the pods makes it an excellent pea for shipping long distances. Very early and uniform grower. A popular sort with canners and shippers. Firstclass in every respect. Height $2 \frac{1}{2}$ feet. Price-20c per pt.; 30c per qt.; $\$ 2.25$ per pk.; $\$ 8.00$ per bu.

FIRST AND BEST. A very good strain, only two or three days later than the Alaska. It is largely planted by truckers. Price-20c per pt.; 30c per qt.; \$2.25 per pk.; $\$ 8.00$ per bu.

TOM THUMB. A very early variety which grows only about 10 inches high. It yields well. Is good for small gardens. Price-20c per pt.; $30 \mathrm{c}$ per qt.; $\$ 2.25$ per pk.; $\$ 8.00$ per bu.

AMERICAN WONDER. One of the earliest wrinkled peas of very good quality; grows about 10 inches high and is very productive. Price-25c per pt.; 40c per qt.; $\$ 2.75$ per pk.; $\$ 10.00$ per bu.

MeLEAN'S LITTLE GEM. One foot high; bears heavily and of excellent quality; slightly later than the American Wonder. A favorite sort. Price-25c per pt.; 40e per qt.; $\$ 2.75$ per pk.; $\$ 10.00$ per bu.

NOTT's EXCELSIOR. This extra fine pea will stand planting very early, almost as soon as the smooth sorts, and produces fine, large pods, onethird larger than American Wonder. Dwarf in habit; height 1 foot. Price-25e per pt.; 40c per qt.; \$2.75 per pk.; $\$ 10.00$ per bu. 


\section{PEAS----Continued}

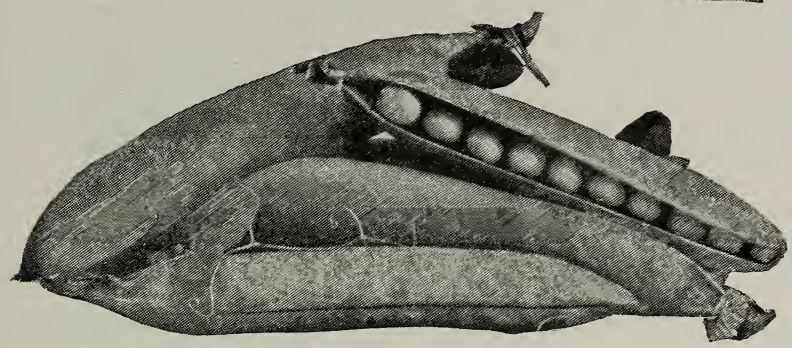

\section{Dwarf Telephone or Daisy}

I market-gardened a number of years, and if I were offered only two varietics of peas I would choose Alaska for early and Dwarf Telephone for main crops. It is a cross between the Standard Telephone and Stratagem, and is an improvement on both of these varieties. It grows 18 inches high and yields an abundance of long, well-filled pods, containing from 7 to 11 large wrinkled peas of the finest quality.

A vigorous growth is characteristic of this sort. For the market or home garden there is none better. Every planter should have some of this. My crop this year was good, notwithstanding the general short crop.

Price-25c per pt.; $45 \mathrm{c}$ per qt.; $\$ 3.00$ per pk.; $\$ 11.00$ per bu.; $\$ 10.50$ per bu. in 10-bu. lots.

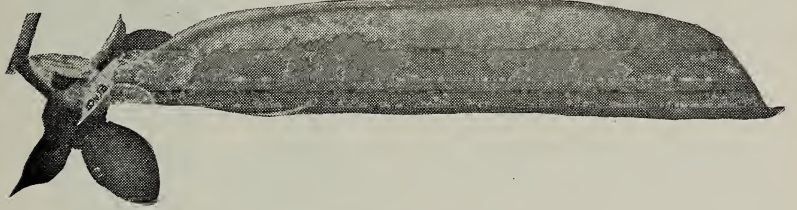

\section{Telephone}

The Telephone has become one of the leading peas with market gardeners whose trade appreciates fine appearance and high quality. Vines vigorous, growing about 4 feet high, with large, coarse, light-colored leaves and producing an abundance of very large pointed pods filled with very large peas which are tender, sweet and of excellent flavor. It comes into use soon after the Premium Gem and is one of the best sorts for either home or market.

Price-20c per pt.; 35c per qt.; $\$ 2.25$ per pk.; $\$ 8.50$ per bu.

\section{Yorkshire Hero}

Vines stout, about $2 \frac{1 / 2}{2}$ feet high, bearing at the top a number of broad pods filled with large peas that remain a long time in condition for use and which never become as hard as most sorts. The peas are of fine quality and will be preferred to any other by those who like a rich, marrow-like pea. Seed large, wrinkled and flattened.

Price-20c per pt.; 35c per qt.; \$2.25 per pk.; \$8.50 per bu.

Add $8 \mathrm{c}$ per pint or $15 \mathrm{c}$ per quart, if by mail, on all peas. 


\section{PEAS---Continued}

\section{Stratagem}

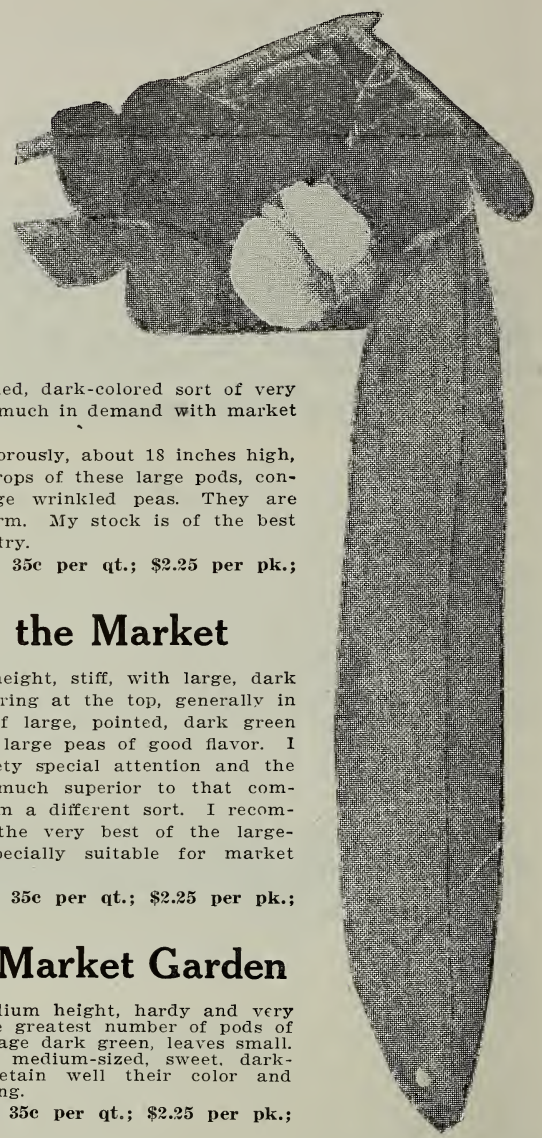

This is a long-podded, dark-colored sort of very fine quality which is much in demand with market growers.

The vines grow vigorously, about 18 inches high, and bear abundant crops of these large pods, containing 9 to 11 large wrinkled peas. They are very large and uniform. My stock is of the best prodiced in the country.

Price-20c per pt.; 35c per qt.; $\$ 2.25$ per pk.; $\$ 8.50$ per bu.

\section{Pride of the Market}

Vines of medium height, stiff, with large, dark green leares and bearing at the top, generally in pairs, a good crop of large, pointed, dark green pods well filled with large peas of good flavor. I have given this variety special attention and the stock I offer is so much superior to that commonly sold as to seem a different sort. I recommend it as one of the very best of the largepodded varieties, especially suitable for market cardeners.

Price-20e per pt.; 35e per qt.; $\$ 2.25$ per pk.; $\$ 8.50$ per bu.

\section{Horsford's Market Garden}

The vine is of medium height, hardy and very productive, giving the greatest number of pods of any on our list. Foliage dark green, leaves small. Pods contain 5 to 7 medium-sized, sweet. darkgreen peas which retain well their color and sweetness after canning.

Price-20e per pt.; 35e per qt.; \$2.25 per pk.; $\$ 8.50$ per bu.

LARGE WHITE MARROWFAT. Late variety, large, well-filled pods. Vines hardy, strong and vigorous; pods fine, broad and of a leathery appearance and borne near the top of the vine. Contain 5 to 6 large peas of good substance and flavor, but not so sweet as the wrinkled sorts. For many years this has been used in immense quantities by canners. The peas are large, round, white and slightly oval. Height of vine, $3 \frac{1}{2}$ feet. Price-15e per pt.; 25e per qt.; $\$ 1.50$ per pk.; $\$ 5.00$ per bu.

BLACK-EYED MARROWFAT. Growth and general characteristics similar to the above. The peas have a distinct black eye, which does not show when they are in the green state. Is more prolific than the white. Price-15e per pt.; 25e per qt.; $\$ 1.50$ per pk.; $\$ 5.00$ per bu.

BLISS EVERBEARING. A late variety which grows about 24 inches high and continues long in yielding. The peas are of excellent quality Pods contain 5 to 7 peas so closely filled that while in edible condition they weigh nearly one-ffth more than most other sorts. Price-20c per pt.; 35c per qt.; $\$ 2.00$ per pk.; $\$ 7.75$ per bu.

Add $8 \mathrm{c}$ per pint, $15 \mathrm{c}$ per quart, if by mail. 


\section{PARSNIPS}

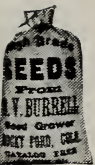

Prepare a seed bed as for beets. Drill in rows 18 inches apart, covering the seeds one-half inch deep. The seeds germinate slowly, and a few lettuce seed mixed with the parsnip will come up quickly and mark the row so you can cultivate the parsnip before it comes up, if desired.

Plant the seed very early, as soon as the soil will do to work. Give frequent cultivation and thin to 4 inches apart in the row.

Parsisips are of great value both for the table and for feeding stock. They yield an abundant crop.

Plant 4 pounds of seed per acre; $1 / 4$ oz. to 100 feet of drill.

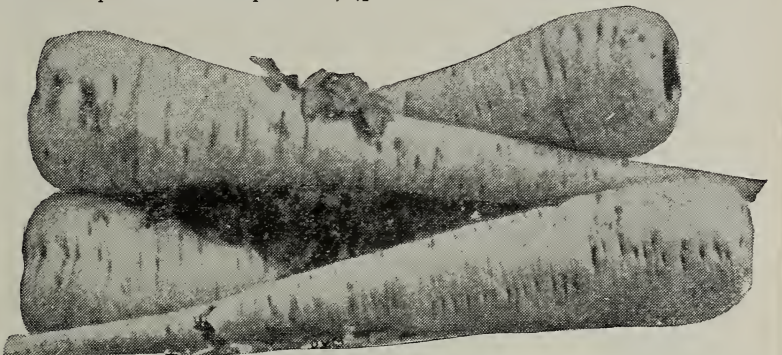

\section{Hollow Crown or Large Sugar Parsnip}

This is a very desirable sort; productive, large, smooth white skin, uniform in shape, tender and of best quality.

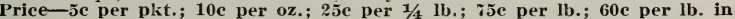
10-lb. lots and up.

\section{Guernsey}

A very fine variety which does not grow so long as the Hollow Crown, but brcader shouldered. It is easily gathered, and yields an abundance of very smooth, fine-grained roots.

Price-5e per pkt.; 10c per oz.; 25e per $1 / 1 \mathrm{lb.;} 75 \mathrm{c}$ per $1 \mathrm{b.;} 60 \mathrm{c}$ per $1 \mathrm{~b}$. in 10-lb. lots and up.

\section{Peppers}

Give peppers the same cultural methods as egg plant. (See egg plant).

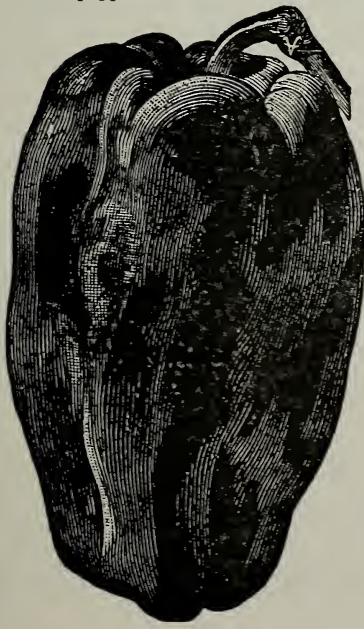

\section{Select Ruby Giant}

Iy seed of this variety is extra fine. Many who planted it for market report having grown the finest and most profitable crop they ever grew. I sell large quantities of this seed to individual growers and associations.

The fruits are very large, often measuring 5 inches in length and 3 to $3 \frac{1}{2}$ inches in diameter. AN EXCELLENT MANGO PEPPER.

The best and most profitable mild red pepper for market or family use; so sweet and mild that they can be eaten raw, like an apple; largest size:

Price-5c per pkt.; 25e per oz.; 80c per $1 / 4$ Ib.; $\$ 3.00$ per lb.; $\$ 2.90$ per $1 b$. in 5 -lb. lots and up.

\section{Ruby King}

This is a well-known and excellent variety, shaped as shown in cut. Green when suitable for mangoes; very mild and a profitable sort to grow.

Price-5c per pkt.; 20c per oz.; 70c per $1 / 4$ lb.; $\$ 2.70$ por lb.; $\$ 2.60$ per $1 b$. in $5-16$. lots and up. 


\section{PEPPERS---Continued}

\section{Chinese Giant Pepper}

A very large variety of extra fine quality. Not so long as Ruby King, kut thicker, and one of the best mango peppers. Well known and well liked by market growers.

Price-5e per pkt.; 40c per oz.; $\$ 1.40$ per $1 / 4 \mathrm{lb}$.; $\$ 5.00$ per $1 \mathrm{lb}$; $\$ 4.90$ per lb. in 5-lb. lots and up.

LONG RED CAYENNE. A small, long bright red sort, very productive, extremely strong and pungent. Price-5e per pkt.; 15c per oz.; 50c per $1 / 4 \mathrm{lb}$.; $\$ 1.75$ per $1 \mathrm{lb}$.

LARGE BELL OR BULL NOSE. A favorite and well-known pickling sort; is early, large, mild and thick-skinned. Price-5c per pkt.; 15c per oz.; 50c per $1 / 4 \mathrm{lb}$.; $\$ 1.75$ per $1 \mathrm{~b}$.

MAMMOTH GOLDEN QUEEN. One of the largest, handsomest and most productive of all varieties; color bright golden yellow; large as Ruby King; flavor mild and pleasing. Price-5e per pkt.; 20c per oz.; 60e per $1 / 4$ lb.; $\$ 2.30$ per $1 b$.

SWEET SPANISH. Grows to very large size; sweet flavor, fine for salad. Price-5c per pkt.; 20c per oz.; $60 \mathrm{c}$ per $1 / 4 \mathrm{lb}$.; $\$ 2.30$ per $\mathrm{lb}$.

MEXICAN CHILI. Used by the Mexicans in making the famous chili con carne and hot tamales. Grows from 3 to 5 inches lorig and quite pointed. Requires a long, warm season. Plants should be started quite early in hot beds. I offer my customers the following low prices on this seed: 5e per pkt.; $15 \mathrm{c}$ per oz.; $40 \mathrm{c}$ per $1 / 4 \mathrm{lb}$.; $\$ 1.40$ per $\mathrm{Ib}$.

RED CHERRY. Plants tall, bearing a profusion of bright red, round fruit, which is very pungent when ripe. The plant is very handsome and an ornament to the garden. Price-5e per pkt.; 25c per oz.; 70c per $1 / \mathbf{4} \mathbf{~ l b . ;}$ $\$ 2.70$ per $1 \mathrm{~b}$.

\footnotetext{
Add $8 \mathrm{c}$ per pound if by mail.
}

\section{Rhubarb}

Rhubarb is one of my specialties, and this year my crop of seed was a large portion of the entire product of this seed.

Rhubarb is one of the most valuable early garden products, and every one of my customers should grow some of it. Rhubarb pies, rhubarb-sauce and rhubarb jelly are very fine. The leaf stalk is used. It is the earliest spring vegetable.

Culture.-Rhubarb seea may be drilled in rows 2 feet apart, covering the seed 1 inch deep. Thin the plants to 6 inches apart in the rows.

When 1 year old transplant either in the fall or spring to the permanent bed which has been previously prepared by manuring heavily and plowing deep, setting the plants 4 feet apart in rows 6 feet apart. Give a heavy coat of manure each spring. Cultivate well and ridge slightly. Do not gather any of the rhubarb from the permanent bed until the second year and do not pull off more than half the stalks at any one time, as this weakens the plants.

When seed stalks appear, break them off, as if the plants run to seed they become exhausted and produce small stalks.

Rhubarb seed does not reproduce true, and while good results obtain from seed, the best plan is to set out clumps containing two and three eyes each, cut from old crowns which have produced the class of stalks desired.

I recommend the clumps which I offer below as being from crowns which have produced very large scarlet stalks of the finest quality, either for home use or market.

\section{Rhubarb Linnaeus}

As stated above, this seed does not reproduce true. My seed, of which I grow thousands' of pounds is produced from selected crowns, and better cannot be had.

Price-5c per pkt.; $10 \mathrm{c}$ per oz.; $30 \mathrm{c}$ per $1 / 4 \mathrm{lb}$.; $\$ 1.00$ per $\mathrm{lb} . ; 90 \mathrm{c}$ per $\mathrm{lb}$. in $10-1 b$. lots and up.

\section{Rhubarb Roots}

These roots are cut from select crowns and produce very fine quality of rhubarb. The large crowns are divided into clumps of two and three eyes each.

Price-50c per doz.; $\$ 2.00$ per $100 ; \$ 18.00$ per 1,$000 ; \$ 16.00$ per 1,000 in 10,000 lots. These prices at buyer's expense for transportation. 


\section{RADISHES}

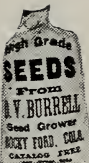

For forcing under glass or in hot beds use a rich sandy soil. Scatter the seeds evenly over the surface, 40 to 50 to the square foot and sift soil crer the seeds, covering about 1 inch deep. Keep the soil moist and of even $t \in m$ perature, at about 70 degrees, for best results. Give good ventilation.

Under thes conditions you should be able to market the whole crop in four to five weeks.

For outdoor culture sow in drills 14 to 18 inches apart as soon as the soil can be worked in the spring. Sow some of the small sorts, and at the same time some of the long. I prefer Cincinnati Market and White Icicle. These are ready soon after the small sorts and do not get pithy so soon.

The soil should be very rich, and if under irrigation, water regularly to keep the plants continuously growing, but do not water too heavily.

I am very careful to have the best seed produced, and where better results are had by so doing I offer seed from transplanted roots. This applies particularly to my Cincinnati Market. Many who buy large lots of this seed state they have not been able to secure its equal elsewhere. Ten to 12 pounds of seed per acre; $1 \mathrm{oz}$. to 150 feet of drill.

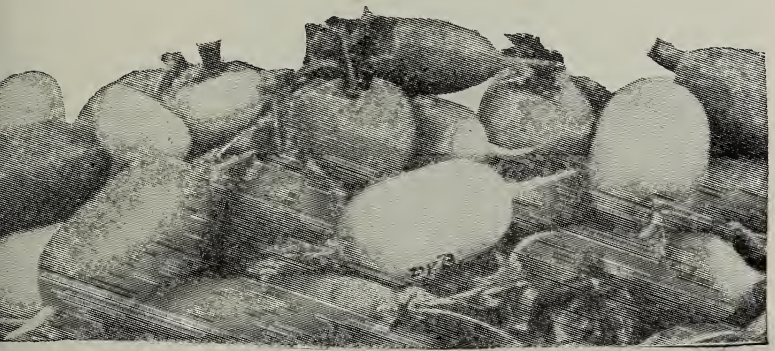

CRIMSON GIANT. This valuable early sort is one of the finest for extra early; color very deep scarlet; very solid, slow to get pithy and very desirable for the home garden or early home market. Excellent to grow under glass. Price-5e per pkt.; 10c per oz.; 20c per 1/4 lb.; 65c per lb.; 60c per lb. in 10-lb. lots and up.

EARLY SCARLET TURNIP. A fine, quick growing sort; small, round, crisp, tender, of good eating qualities. Price-5e per oz.; 15c per $1 / 2 \mathrm{lb}$; 50c per lb.; \$4.50 per 10 lbs.

ROSX GEM OR WHITE TIPPED FORCING. One of the quickest sorts and of excellent quality. Bright scarlet with white tips; of fine appearance. Price-5e per oz.; 15e per $1 / 4 \mathrm{lb}$.; 50c per lb.; $\$ 4.50$ per $10 \mathrm{lbs}$.

EARLY WHITE TLRNIP. Of quick growth; roots round, white, with small tops. Good for forcing or open ground. Flavor very good. Price -5c per oz.; $15 \mathrm{c}$ per $1 / 4 \mathrm{lb}$; $50 \mathrm{c}$ per $1 \mathrm{~b} . ; \$ 4.50$ per $10 \mathrm{lbs}$.

FRENCH BREAKFAST. (Olive shaped). Deep crimson with white tips. A well-known and equally well-liked variety. One of the best early radishes. Price-5e per oz.; $15 \mathrm{e}$ per $1 / 4 \mathrm{lb}$.; 50c per lb.; $\$ 4.50$ per $10 \mathrm{lbs}$.

EARLY SCARLET. (Olive shaped). Oval, very tender and good quality; fine for forcing or open ground. Price-5e per oz.; 15e per $1 / 4$ lb.; 50c per lb.; $\$ 1.50$ per 10 lbs.

SURPRISE. (Olive shaped). Skin brown, flesh white, crisp and tender. Price-5c per oz.; 15c per $1 / 4 \mathrm{lb}$; 50c per lb.; $\$ 1.50$ per $10 \mathrm{lbs}$.

EARLY WHITE. (Olive shaped). Small, sweet and crisp. Like the other olive-shaped sorts except in color. Price-5e per oz.; 15e per $1 / 4$ lb.; 50c per lb.; $\$ 4.50$ per 10 lbs. 


\section{RADISHES----Continued}

\section{Burrell's Long Cincinnati Market}

Special Market Gardeners' Strain

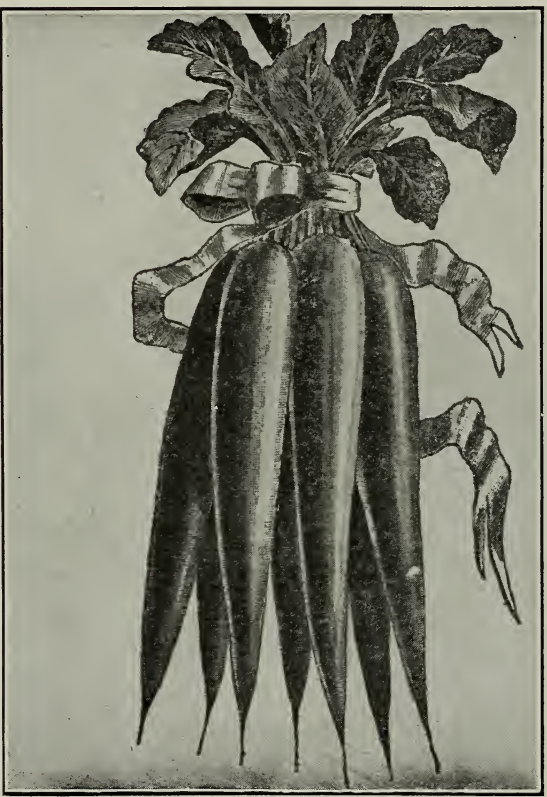

Single Market Gardeners buy 50 to 100 pounds of this seed from me at a time. The finest Long, Light, S c a r le t Radish, nearly t r a n s p a rent, small tops, will stand planting close together, slow to run to s e ed; g row s straight and smooth, 6 to $s$ inches long, tender, crisp and does not become hollow and pithy. If you grow for $\mathrm{m}$ a $\mathrm{rk}$ e $\mathrm{t}$ and plant only two sorts they should be my Long Cincinnati Market and $\mathrm{New}$ White Icicle. Price-5e per pkt.; 10c per oz.; 20c per $1 / 4$ lb.; 65 per $1 \mathrm{~b} . ;$; $60 \mathrm{c}$ per lb. in 10 to 40-1b. lots.; 55e per lb. in $40-1 b$. lots and up.

Long Chartier

A well - liked sort, which attains a very large size before becoming unfit for use. Color, red at $t h e$ to $p$. changing to pink in the middle and white at the tip. Many market gardeners plant this exclusively for their market trade. Price-5c per oz.; $15 \mathrm{c}$ per $1 / 4 \mathrm{lb}$.; 50c per $\mathbf{l b . ;} \$ 4.50$ per $10 \mathrm{lbs}$.

\section{Long Scarlet Short Top}

The standard long variety. Well known for a long time. Good for home or market garden. Roots long, growing partly above the ground: straight, smooth, rich red and of fine quality; a quick grower. Price-5e per oz.; 15 c per $1 / 1 / 1$ lb.; $50 c$ per $1 b$.; $\$ 4.50$ per 10 lbs.

\section{Long Brightest Scarlet}

This new sort much resembles Long Scarlet in shape, but is slightly shorter. It is a very bright scarlet with a white tip and very attractive in appearance. The quality is extra good and it matures quickly. It is a good seller and fine for home gardens as well. Price-5c per oz.; 15c per $1 / 4$ lb.; 50c per lb.; $\$ 4.50$ per 10 lbs.

\section{CALIFORNIA WHTE IVINTER.}

Is really a Chinese Radish, grown by the Chinese in California. White, solid, of good flavor, and a long keeper; 8 to 10 inches long, and 2 to 3 inches in diameter. Price-5e per oz.; $15 c$ per $1 / 4$ lb.; 50c per lb.; $\$ 4.50$ per $10 \mathrm{lbs}$.

LONG BLACK SPANISH.

Black shinned, large roots, slightly pungent, hardy. Price-5e per oz.; $15 \mathrm{c}$ per $1 / 4 \mathrm{lb}$.; 50c per lb.; $\$ 4.50$ per $10 \mathrm{lbs}$. 


\section{SPINACH}

No plant makes more palatable and nutritious greens than spinach when properly prepared. Seed should be planted in very rich ground, the richer the better. Sow in drills 16 to 20 inches apart and thin to about 6 inches apart when the leaves are an inch wide. All should be cut before hot weather, while young and tender. For early spring use sow early in autumn and protect the plants with a light covering of leaves or straw, or plant as soon as the land can be worked in the spring. Under favorable conditions the leaves may be large enough for eating in eight weeks. In the South spinach can be grown through the winter with very little or no covering. Eight to 10 pounds of seed per acre; 1 ounce to 100 feet of drill.

\section{New Zealand Spinach}

This variety of recent introduction differs from other varieties in that it can be planted in hot weather and thrives throughout: the summer. The rows should be about 2 feet apart and plants 6 to 8 inches apart in the rows.

The tender shoots are of good quality, and this variety is much liked by Southern planters, especially in the Imperial Valley of California

Price-5e per pkt.; 10c per oz.; 20c per $1 / 4$ lb.: 70e per lb.; 60c per lb. in $10-1 \mathrm{~b}$. lots and up to 50 los.; $50 \mathrm{c}$ per $1 \mathrm{~b}$. in 50 -lb. lots and up.

\section{Savoy Leaved}

Also known as Bloomsdale. A very early variety and one of the best to plant in autumn for early spring use. The plant is of upright growth, with thick, glossy, dark green leaves of medium size, pointed but quite with thick, glossy, dark green leaves of medium size, pointed but quite round. It is hardy and grows rapidly to a suitable size for use, running to seed quickly in warm weather.

Price-5e per oz.; $15 \mathrm{c}$ per $1 / 4 \mathrm{lb}$.; $40 \mathrm{e}$ per $\mathrm{lb}$.; $30 \mathrm{c}$ per $1 \mathrm{~b}$. in $10-\mathrm{lb}$. lots; $25 \mathrm{e}$ per $\mathrm{lb}$. in $50-1 \mathrm{~b}$. lots. Special prices on large lots.

\section{Long Standing}

An improved round seeded strain of excellent quality; season comparatively late, but after reaching maturity it remains in condition for use much longer than most sorts. Plant very large, becoming rather spreading when mature; leaves usually very broad arrow shaped or rounded. comparatively smooth and dark, rich green. Very popular with market gardeners.

Price-5e per oz.; $15 \mathrm{c}$ per $1 / 4$ lb.; $40 \mathrm{c}$ per $1 \mathrm{~b}$.; 30c per $1 \mathrm{~b}$. in 10-1b. lots; 25e per $1 b$. in $50-1 b$. Jots. Special prices on large lots.

\section{Large Round Leaved Viroflay}

An 'xcellent sort, forming a very large, exceedingly thick, very dark green leaf slightly crumpled in the center. Plant large, compact; season intermediate. Leaves usually blunt or rounded at end, but sometimes broad arrow shaped. Seed round. The variety becomes fit for use nearly as early as any, remaining so much longer than most kinds and cannot fail to please, whether grown for the market or home garden.

Price-5e per oz.; $15 \mathrm{c}$ per $1 / 4 \mathrm{lb}$.; $40 \mathrm{c}$ per $\mathrm{lb}$.; 30e per $\mathrm{lb}$. in $10-1 \mathrm{~b}$. lots; $25 \mathrm{c}$ per $1 \mathrm{~b}$. in 50-1b. lots. Special prices on large lots.

\section{Prickly Winter}

An improved strain of the long standing type of spinach. Plant very large at maturity, with many medium-sized leaves, very vigorous and hardy. Leaves usually rounded at end, quite thick and uniformly dark green. Seed prickly. Usually planted in the fall, but also well adapted for spring use.

Price-5e per oz.; 15e per $1 / 4$ lb.; 40e per 1b.; 30c per lb. in 10-1b. lots.

\section{Swiss Chard}

This is really of the beet family. The mid-leaf, which is very broad, white and tender, is cooked much like asparagus; also grown extensively for chickens.

Price-5e per pkt.; 10c per oz.; 25e per 1/4 lb.; 80c per lb. 


\section{SQUASH}

The cultural methods for melons and cucumbers will apply. Plant summer sorts 3 to 4 feet each way and thin to ply. Plant summer winter sorts 6 one plant when they have five or six leaves. Winter sorts 6 rich. Handle very carefully when harvesting, so as not to bruise them and injure the keeping qualities. Cut from the ine, ltaving the stem on the squash; store where there is no danger of freezing. For insects, see pumpkins. Plant 3 pounds of seed per acre.

\section{Early Mammoth Yellow Summer Crookneck}

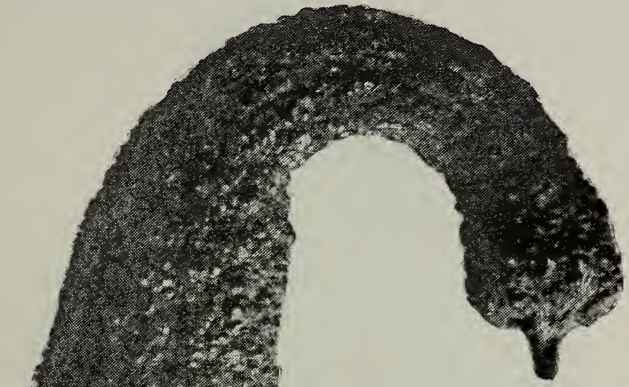

My strain of this variety is very fine. The result of individual selection covering a period of many years. (See cut for appearance). They are attractive in appearance, uniform in quality and the finest crookneck for early market.

Price-5e per oz.; 20e per $1 / 4$ lb.; 65 c per lb.; $60 \mathrm{c}$ per lb. in $10-$ lb. lots; 50c per lb. in 100-ib. lots.

\section{Summer Crookneck}

The old standard sort; early and very productive. Matures the bulk of its crop a little earlier than the Mammoth $\mathrm{Sum} \mathrm{mer}$ Crookneck. Fruits when fully grown are about 1 foot long, with uniformly erooked neck and surface densely warted; color bright yellow. Shell very hard when ripe.

Price-5e per oz.; 20e per $1 / 4$ lb.; 60e per lb.; $55 \mathrm{c}$ per lb. in 10-lb. lots; $45 \mathrm{c}$ per lb. in $100-1 b$. lots.

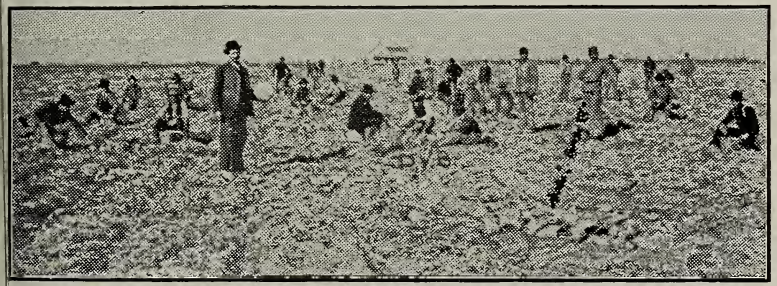

Burrell's Select Early Mammoth White Bush Squash

\section{EARLIEST, FINEST STRAIN FOR MARKET GARDENERS.}

I grow a large acreage of squashes for seed, and call your attention to the photograph taken in one of my fields. When you buy of me you are getting the seed from the grower and can be assured of the fact that I take the greatest care to have the seed right in quality.

This squash is very early and just the right size for market. The bush habit is well established and the uniform appearance makes it a profitable sort when it comes to packing, as the fruits all look alike.

Price-5e per oz.; 20c per $1 / 4$ lb.; 65e per lb.; 60e per lb. in 10-1b. lots; $50 \mathrm{c}$ per $1 \mathrm{~b}$. in $100-1 \mathrm{~b}$. lots.

\section{DWARF IVHITE BUSH SCALLOP.}

A small, well-known sort much grown for market. Bush habit not so well established as Mammoth White Bush.

Price-5e per o\%,; 20c per $1 / 4 \mathrm{lb}$.; 60e per $1 b . ; 50 c$ per $1 b$. in 10-lb. lots. Add $8 \mathrm{c}$ per pound if by mail. 


\section{SQUASH----Continued}

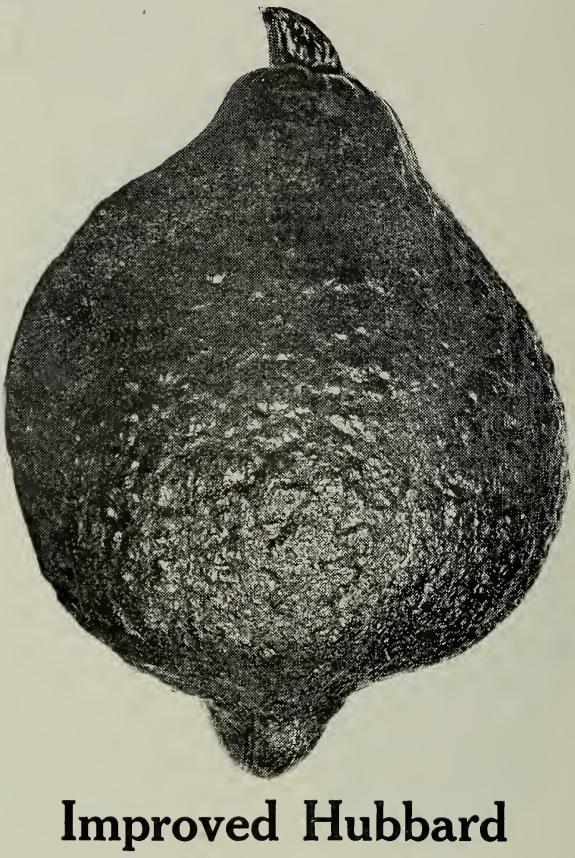

This is the standard variety and has no superior. If you are planting but one variety for winter I would recommend that this be the Hubbard. It is a favorite both for market and home use. Good specimens are about equal to the sweet potato. The shell is hard and dry, and with some care can be kept until late in the spring. My strain is very fine. Price-5e per pkt.; $10 \mathrm{e}$ per oz.; $25 \mathrm{c}$ per $1 / 4$ lb.; 70e per 1 b.; $\$ 6.50$ per $10 \mathrm{lbs}$.; $\$ 60.00$ per 100 ibs.

CHICAGO WARTEI HUBBARD. This very fine variety much resembles the Original Hubbard except that it is larger and more covered with warts. Can be kept until late spring. The shell is very hard and dry. Price-5e per pkt.; 10e per oz.; 25e per $1 / 4$ lb.; 70e per $1 b . ; \$ 6.50$ per 10 lbs.; 60e per $1 \mathrm{~b}$. in $25-1 \mathrm{~b}$. lots and up.

GOLDEN HUBBARD. This is slightly smaller than the Original Hubbard and instead of having a slate green rind, it is a rich golden color. In quality it is unsurpassed. It is an excellent keeper. Price-5e per pkt.; 10e per oz.; 30c per 1/4 lb.; 90c per 1 b.; 85 e per $1 b$. in $10-1 b$. lots and up.

GOLDEN BRONZE. A very fine sort; flesh thick, deep reddish orange color; fine grained and of excellent flavor. A good keeper; shape oval, largest at blossom end; the rind is golden bronze in color when ripe. Price-5e per pkt.; $10 \mathrm{c}$ per oz.; 30c per $1 / 4 \mathrm{lb}$.; $90 \mathrm{c}$ per $1 \mathrm{lb}$; $85 \mathrm{e}$ per $1 \mathrm{~b}$. in 10-lb. lots and up.

PIKE'S PEAK. An excellent sort, rather long for its thickness; slate colored rind; flesh creamy yellow, of good tlavor; a good keeper. Price5e per pkt.; $10 \mathrm{c}$ per oz.; $25 \mathrm{e}$ per $1 / 4 \mathrm{lb}$.; $80 \mathrm{c}$ per $1 \mathrm{lb}$; $75 \mathrm{e}$ per $\mathrm{lb}$. in $10-1 b$. lots and up.

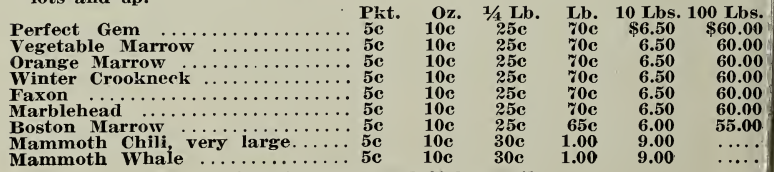

Add 8c per pound if by mail. 


\section{TOMATO}

For very early fruit the seed should be sown in a hot bed about the first week in March in drills 5 inches apart and half inch deep. Later sowings may be made until the last of April. Sufficient plants for a small garden may be started by sowing a few seed in a shallow box or flower pot and placing in a window in the house. When the plants are 3 or 4 inches high they should be set out 4 or 5 inches apart in another hot bed or cold frame, or removed into small pots, allowing a single plant to a pot. Expose to the air as much as possible to harden. Water freely at time of transplanting and shelter from the sun a few days until the plants are established. Cultivate thoroughly as long as vines will permit, but the last two or three workings should be very shallow (surface cultivation) or the crop may be badly injured, especially if the cultivator is run too near the plants. Tomatoes will admit of training to stakes or trellises, and the fruit is very much improved, not only in appearance but in quality. This mode of cultivation is quite common among gardeners who grow for early market. The usual method is to set one strong plant to a stake 5 to 7 feet high, tying the plants up with wool or other strong, soft twine, pruning out quite freely as vines advance in growth. By this method plants may be set much closer than in the ordinary way. For fine, large specimens of high color and attractive appearance generally, grow the clusters of the fruit in paper sacks, as is commonly practiced by grape growers. The sacks should be put on when the tomatoes are about three-fourths grown. About 2,000 plants from 1 ounce of seed is a safe estimate.

\section{What About the Price of Tomato Seed}

Yes, I make a good profit on tomato seed at $\$ 1.00$ per ounce, but no more than the gardener who grows select early tomatoes and sells them for 5c per pound, and it takes the finest of these very early tomatoes to produce this best seed. Then, by planting an ounce of this choice seed at $\$ 1.00$, you have only to sell 20 pounds of early tomatoes per acre at $5 \mathrm{c}$ per pound to pay for this seed, and a good crop may enable you to average $5 \mathrm{c}$ per pound for 2,000 to 3,000 pounds per acre, besides giving you a total yield of 12 to 20 tons per acre. It is only this: The best seed is the lowest in cost and the person making a specialty of carefully selecting the seed should get a price for it equal to what may reasonably be expected for the early fancy tomatoes on the market.

My general list of tomato seeds are selected from tomatoes grown exclusively for seed, all the good fruits of the crop being cut. This seed is grown from carefully selected stock seed, which is in turn grown from very select specimens in stock seed plots, but my finest seeds are grown from the finest selection of stock seeds, and the seeds offered are again selected from the finest first fruits to ripen.

I sell tomato seeds to thousands of market growers, and four out of five buy the best seeds. Many of these persons have planted this best seed for several years and continue to order them each year. 


\section{TOMATO----Continued}

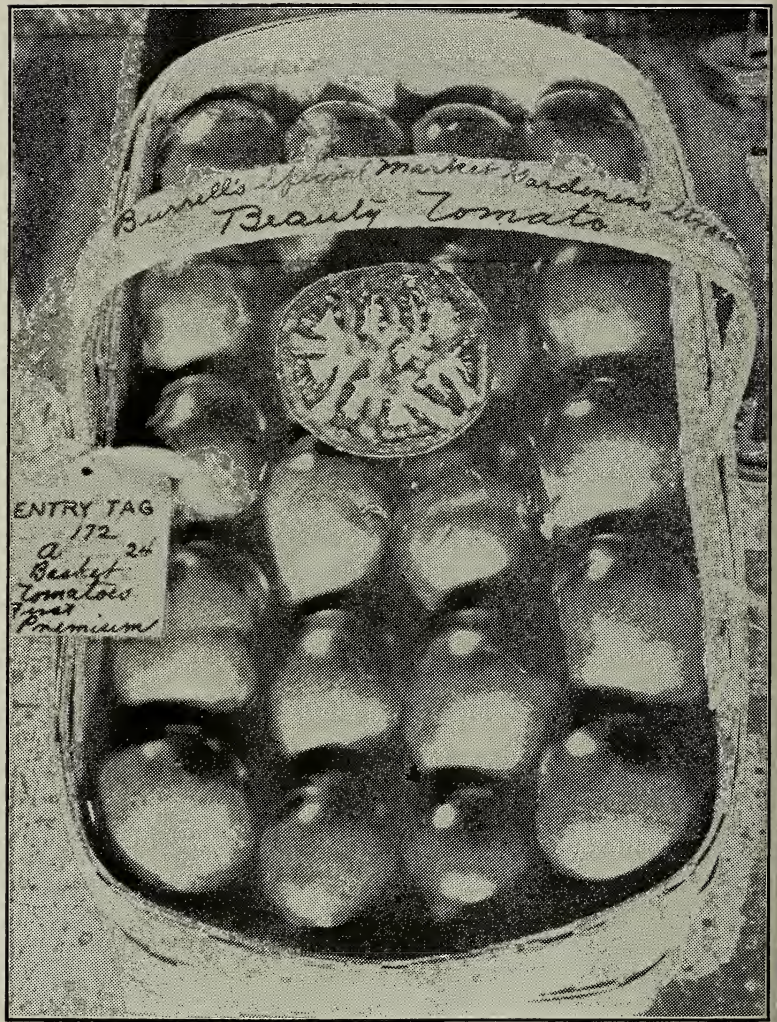

MARKET GARDENERS' STRAIN BEAUTY TOMATO.

This strain has been carefully selected for a number of years, until it is now far ahead of the seed of this variety usually offered. The photo above is of a basket of these tomatoes which won first premium at the Rocky Ford Fair. On the market 8 -pound baskets of these sold readily at $50 \mathrm{c}$ per basket, when 20-pound baskets of ordinary tomatoes were selling at $75 \mathrm{c}$ per basket, nearly double the price of ordinary tomatoes. It pays to plant only the best.

This strain is not offered through any other source. Those who secure a supply will be fortunate.

Remember, an ounce of seed produces 2,500 to $\delta, 000$ plants, and at the price per ounce, the cost compared with the crop is practically nothing.

No better sort for hnme garden or shipping; hardy, strong grower, productive; fruits large, smooth and of excellent quality. Color a glossy crimson tinged with purple. Grows in clusters of four to six large fruits and retains its large size late in the season. The flesh is firm skin tough, and it seldom rots or cracks after it rains. They can be picked as soon as there is a slight change in color from green, and ripen up nicely, look well and keep a long time after ripe.

Price-10c per pkt.; 50c per $1 / 2$ oz.; $\$ 1.00$ per oz.; $\$ 3.75$ per $1 / 4$ lb.; $\$ 14.00$ per lb.

I received one order for 100 pounds of this seed last year, $\$ 1,400.00$ Hundreds of the leading tomato growers ordered from 1 ounce to 1 pound. An ounce of this seed may make your crop worth $\$ 100.00$ more than ordinary seed. 


\section{Burrell's Special Selection of Chalk's Early Jewel Tomato}
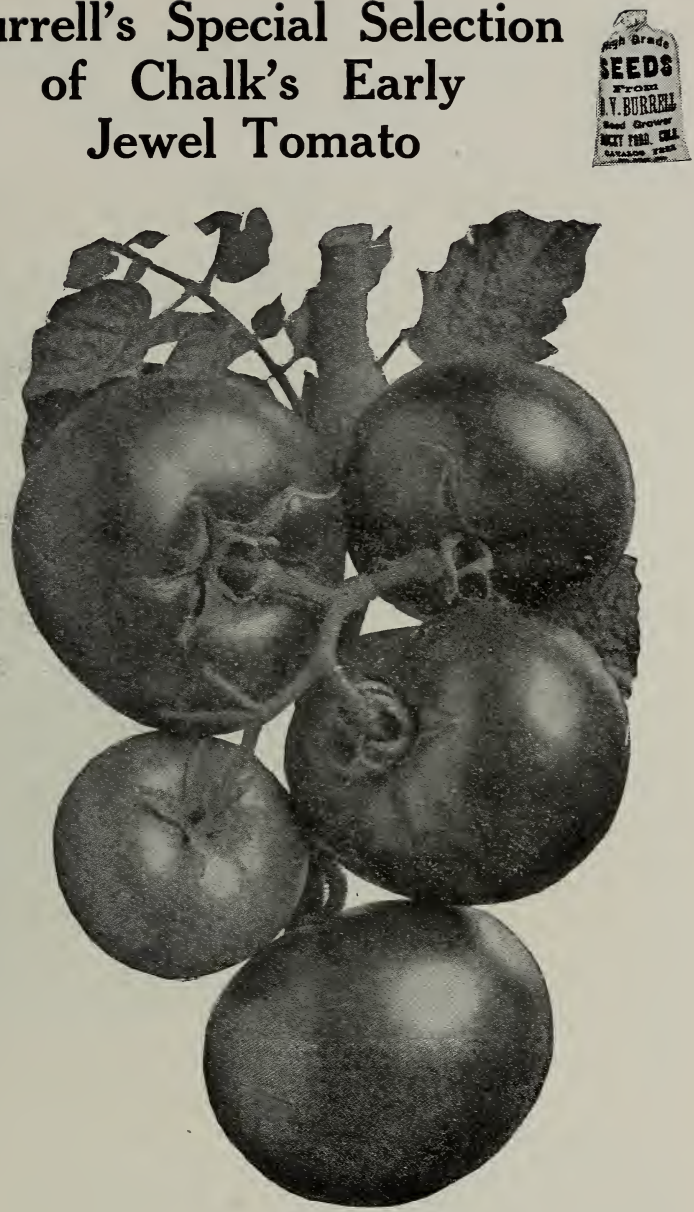

Selecting the very finest specimens of this valuable variety has resulted in this special selection which I have to offer you of my own growing, and I recommend it to the most critical growers. No matter how particular your trade is, no matter how good tomatoes you have been growing, you can afford to plant liberally of this seed.

The fruits begin to ripen four or five days later than the Earliana; are large, bright red, quite solid and very smooth; they ripen without cracks or green core. The flesh is thick and solid, with comparatively few seeds.

I count on establishing as great a record for my special strains of tomato seed as for my special cantaloupe seeds, and believe I am entitled to such a price as will pay me for taking extreme care in selection.

Price-10c per pkt.; 30c per $1 / 4$ oz.; $\$ 1.00$ per oz.; $\$ 3.75$ per $1 / 4 \mathrm{lb}$.; $\$ 7.00$ per $1 / 2 \mathrm{Ib}$. Not over $1 / 2 \mathrm{lb}$. of this grade to one customer.

Standard Grade Chalk's Early Jewel. This is grown especially for seed for me under contract by a tomato seed specialist, but is not my own growing. Price-5e per pkt.; 35e per oz.; $\$ 1.00$ per $1 / 4 \mathrm{lb}$.; $\$ 3.75$ per lb.; $\$ 3.50$ per $\mathrm{lb}$, in $5-\mathrm{lb}$, lots and up. 


\section{Spark's Earliana Tomato, Burrell's Special}

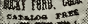

This Extra Early, red tomato has been the source of large returns with many market tomato growers. The plants grow rather open and are loaded with fruits. Will grow best set about $31 / 2$ feet apart each way and by starting the plants early in hot beds you will have to $\mathrm{m}$ a $\mathrm{t}$ o e $\mathrm{s}$ about sixty days after setting out the plants. The bright red fruits are quite uniform in shape, good marketable size and very smooth for so early a sort. The habit of growth is such that the vines do not hide the fruits, making them less liable to sunscald, as from the first they become accustomed to the direct rays, and also allowing them to be picked at small expense.

They are borne in large clusters and the yield is heavy.

This strain is far ahead of the Standard Earliana seed. One of the most critical seedsmen of the United men of the United field the season of 1909 and wanted to purchase of this seed to introduce it as a novelty. He stated they were the finest Extra Early tomatoes he had ever seen, and were entitled to a distinct place because of their superior quality.

If Extra Early tomatoes of the finest quality will make you

money, or if you live in the North where it is dificult to get the tomatoes early enough to mature the crop, this is the sort you want.

One of my Iowa customers writes: "I had ripe tomatoes two weeks earlier than any of my neighbors." That would mean a good deal to you, wouldn't it?"'

Price-10c per plkt.; 30c per 1/4 oz.; $\$ 1.00$ per oz.; $\$ 3.75$ per $1 / 4 \mathrm{lb}$.; $\$ 7.00$ per $1 / 2 \mathrm{lb}$. No more than $1 / 2$ pound to one person.

Standard Sparks' Earliana Tomato. This seed is very desirable. It is grown for me by a tomato seed specialist. Price-5e per pkt.; 30c per oz.; 85 c per $1 / 4$ lb.; $\$ 3.20$ per $1 b . ; \$ 3.00$ per $1 b$. in $5-1 b$. lots and up.

\section{Bonny Best Tomato}

BURRELL'S SPECIAL STOCK.

This has proven one of the biggest money-makers with tomato growers. It should be planted wherever tomatoes are grown. North or South, it is equally valuable. It is within a few days as early as Earliana-large, bright red, solid. Evenly shaped and of the finest quality; a good shipper and an excellent sort for canning.

My stock is of the best strain obtainable in the country, and the great care in growing and selecting this stock should recommend it to all particular tomato growers.

If you want extra early tomatoes plant Burrell's Special Bonny Best.

The fruits are borne in clusters, usually of five and the yield is very heary.

Price-10c per pkt.; 30c per $1 / 4$ oz.; $\$ 1.00$ per oz.; $\$ 3.75$ per $1 / 1 / 1 b . ; \$ 7.00$ per $1 / 2$ lb.; $\$ 14.00$ per $1 b$. 


\section{TOMATOES----Continued}

\section{The New Hummer Tomato}

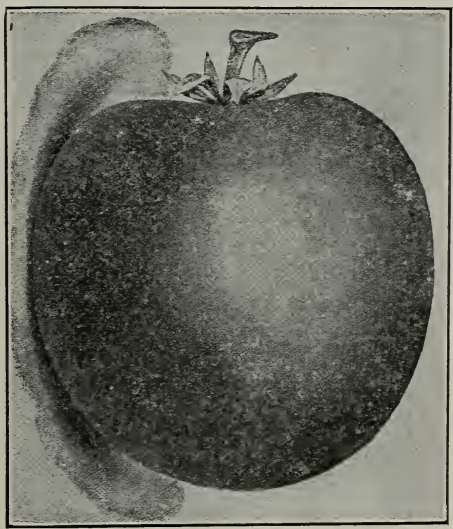

THIS VALUABLE VARIETY was introduced in 1907 and sold by the originator at $1 / 2 \mathrm{c}$ per seed $(20 \mathrm{c}$ per packet of 40 seeds). I secured a supply of this seed from him and grew my supply of seed here under irrigation, where there is no better place to mature the best seed. From this start I selected the seed offered here. It was one of the best crops of tomatoes $I$ have ever grown. A representative of the Kansas City Packer visited the field and stated that he "BELIEVES it the finest sort in cultivation."

The fruits are round, with practically no indentation at the stem, color bright red. Fruit solid with but few seeds set near the rind. No green core; the fruits ripen all over and clear through. The center cuts solid, bright red flesh of extra quality. Almost an extra early sort.

Price-10c per pkt.; 75e per oz.; $\$ 2.75$ per $1 / 1 \mathrm{lb}$.; $\$ 10.00$ per $1 \mathrm{~b}$.

\section{Livingston's Globe Tomato}

This is one of the finest market sorts. The fruits are large, and a good marketable size is retained throughout the season; always smooth, firm-fleshed and with few seeds; ripens evenly; color, a fine glossy rose, tinged with purple, and without the slightest hint of yellow at any stage of ripening. Fruit clusters spring from the main stem much closer together than in most sorts. It is a remarkably good keeper, none of the many varieties we grow surpassing it in this respect. In quality there is nothing more to be desired, being mild, pleasant and of delicate flavor, and the beautiful and attractive globe-shaped fruits will find ready sale. I sell large

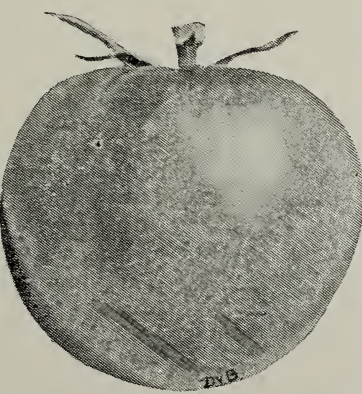
quantities of this seed to Southern growers.

One large Florida grower just wrote me that my Globe tomato seed gave better results than any other Globe tomato seed they could get and wanted more "just like we got last year."

Price-5c per pkt.; 35c per oz.; $\$ 1.00$ per $1 / 4 \mathrm{lb}$.; $\$ 3.75$ per lb. 
JUNE PINK. This sort is among the extra earlies and the fruits are of good quality. It is grown very extensively in many fruit sections, where first in the market means so much. The fruits are medium size, pink, and of good quality. Price-5e per pkt.; 30e per oz.; $\$ 1.00$ per $1 / 4 \mathrm{lb}$; $\$ 3.50$ per lb.; $\$ 3.25$ per $1 \mathrm{~b}$. in 5 -lb. lots and up.

LIVINGSTON'S EARLY ACNE. A tomato especially for early market use. Well-known and generally cultivated, both for early and main crops. Plants are of strong and vigorous growth; very productive: fruits of medium size, perfect form, round, slightly depressed at the ends and very smooth (never rough); color a glossy red, with purplish tinge; ripens all over and through at the same time. Price-5c per pkt.; $20 \mathrm{c}$ per oz.; $60 \mathrm{c}$ per $1 / 4 \mathrm{lb}$; $\$ 2.00$ per $1 \mathrm{~b}$.; $\$ 1.75$ per $\mathrm{lb}$. in $5-1 \mathrm{lb}$. lots and up.

LIVINGSTON'S BEAUTY, STANDARD GRADE. A decided favorite for home, market or shipping; hardy, a strong grower, productive, large, always smooth, perfect shape and excellent quality. Color a very glossy crimson with a tinge of purple. Grows in clusters of four to six large fruits, retaining its large size late in the season. Ripens early and is entirely free from ribbed and enlongated fruit. Flesh very firm, has a tough skin and but few seeds; seldom rots or cracks after a rain. For shipping or early market it cannot be excelled. They can be picked quite green, look well, ripen nicely and keep a week after ripe. Pricelb. lots and up.

THE MIK ADO. Notwithstanding that it produces very large fruits, it is at the same time one of the very earliest grown. The tomatoes are produced in immense clusters, and are perfectly solid, generally smooth, but sometimes irregular. The color is purplish red. Foliage distinct from any other variety. Price-5c per pkt.; 25c per oz.; 70c per 1/4 lb.; $\$ 2.15$ per $1 \mathrm{~b} . ; \$ 2.00$ per $1 \mathrm{~b}$. in $5-1 \mathrm{~b}$. lots and up.

DWARF CHAMPION. Most distinct and valuable. Dwarf, stiff habit, dark green foliage, not needing any support. It is very early and wonderfully prolific. Color same as Acme. It is perfectly round and smooth, of medium size. Price-5e per pkt.; 25e per oz.; 70e per $1 / 4 \mathbf{~ l b . ;}$ $\$ 2.15$ per lb.; $\$ 2.00$ per $1 \mathrm{~b}$. in 5 -lb. lots and up.

NEW STONE. Is a well-known variety, which ripens for main crop; very large and of bright scarlet color; very smooth, with occasionally a specimen slightly octagonal shape; ripening evenly to the stem, and as the name indicates, it is very solid and an excellent shipper. Price-5c per pkt.; 20c per oz.; 60e per $1 / 4 \mathrm{lb}$; $\$ 2.00$ per $1 \mathrm{lb}$.; $\$ 1.75$ per $\mathrm{lb}$. in 5 -lb. lots and up.

MATCHLESS. This new late variety is one of the best, handsomest and heaviest yielders known. The tomatoes are large, bright red and ripen very evenly, yielding few seeds. They are an excellent shipping variety and also good for canning. If you are growing for market plant the Earliana for the early tomato and this for the late. Price-5e per pkt.; $25 c$ per oz.; 70c per $1 / 4$ lb.; $\$ 2.15$ per $l b . ; \$ 2.00$ per $l b$. in 5 -lb. lots and up.

MAGNUS. A distinct and new variety; purple, robust in habit and a good main crop sort. Price-5e per pkt.; 25c per oz.; y0c per $1 / 4$ lb.; $\$ 2.15$ per lb.; $\$ 2.00$ per $\mathbf{l b}$. in 5 -lb. lots and up.

LIVINGSTON'S PERFECTION. The fruit is almost round, ripens clear up to the stem, is solid and rich in flavor. The skin is both thin and tough, making it a good shipper, while its clear, scarlet color makes it most attractive. Price-5e per pkt.; 20c per oz.; 60c per 1/4 lb.; $\$ 2.00$ per lb.; \$1.75 per lb. in 5-lb. lots and up.

PONDEROSA. This is the largest fruited tomato and of fine quality for slicing. 'The vines are of strong, rather open growth; fruits largely oblong in form, deep through and generally ridged or ribbed; deep purple in color. The flesh is solid, with small seed cells, and of fine, sweet flavor. Planted in good soil, fruits frequently attain a weight of 1 pound and over. Rather late to ripen. Price-5e per pkt.; 30c per oz.; $\$ 1.00$ per $1 / 4 \mathrm{lb}$.; $\$ 3.50$ per $\mathbf{l b}$; $\$ 3.25$ per $\mathrm{lb}$. in $5-\mathrm{lb}$. lots and up.

HONOR BRIGHT. A very heavy yielder of uniformly good fruit. The quality is excellent when ripened on the vines, and if picked when first beginning to show solor it ripens in transit to market or when laid on shelves after frost and is of very good quality. One of the best. Price $-5 c$ per pkt.; 25e per oz.; 70c per $1 / 4 \mathrm{lb}$; $\$ 2.15$ per $1 \mathrm{~b} . ; \$ 2.00$ per $\mathrm{lb}$. in 5-lb. lots and up.

PARAGON. Fruit large, dark red in color and perfectly smooth. The flesh is solid and of excellent flavor. It ripens evenly and quickly. Much used for canning purposes. The foliage is heavy. The Paragon is sometimes described as being as smooth as an apple. It is a favorite market variety in certain sections. A fine variety and a heavy bearer. Price5c per pkt.; 25e per oz.; 70c per $1 / 4 \mathrm{lb}$; $\$ 2.15$ per $1 \mathrm{~b} . ; \$ 2.00$ per $\mathrm{lb}$. in 5-lb. lots and up.

LIVINGSTON'S FAvorITE. A large, smooth, dark red variety; a good shipper and canner. Price-5e per pkt.; 20c per oz.; 60c per 1/4 lb.; $\$ 2.00$ per $1 \mathrm{~b}$.; $\$ 1.75$ per $\mathrm{lb}$. in $5-\mathrm{lb}$. lots and up.

WHITE'S EXCELSIOR. A large pink main crop sort of considerable value. In some sections it is a favorite sort. While not an early sort, it is an excellent shipper. Price-5c per pkt.; 20c per oz.; 60e per $1 / 4 \mathrm{lb}$. $\$ 2.00$ per 1 .; $\$ 1.75$ per $1 b$. in $5-1 b$. lots and up.

$\$ 2.00$ per lb.; \$1.75 per lb. in 5-lb. lots and up.
YELLOW PLUU. Fruit plum-shaped, deep yellow color; flesh yellow and good; esteemed for preserves. Price-5c per pkt.; 25c per oz.; 70c per $1 / 4 \mathrm{lb}$; $\$ 2.15$ per $1 \mathrm{~b}$.; $\$ 2.00$ per $1 \mathrm{lb}$. in 5 -lb. lots and up. Add $8 \mathrm{c}$ per pound to all tomatoes for postage if by mail. 


\section{TURNIP}

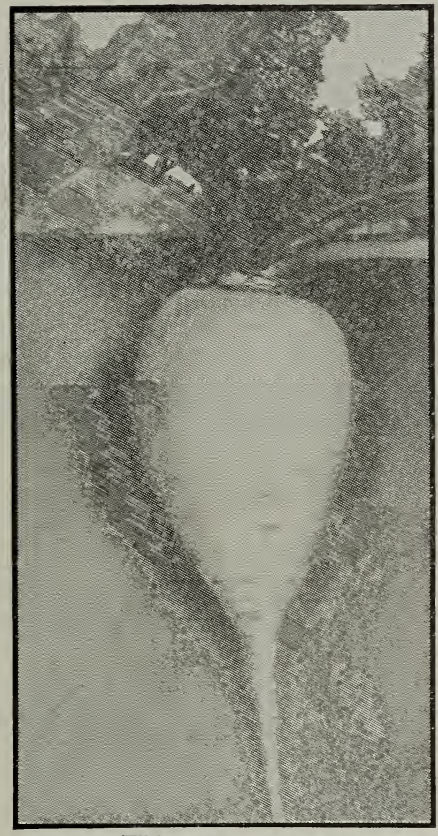

White Egg.

I handle thousands of pounds of turnip seeds and offer of the best seeds. I have these grown by one of the leading European specialists, and after fully testing them com pared with others, I recommend them as of the best.

Every person who plants a garden or field should grow some turnips.

For early use drill in rows or sow broadcast very early in the spring. For winter use sow in July or August broadcast and harrow in the seed.

$\mathrm{Be}$ careful not to get them too thick, as this results in all top and no turnip. One pound of seed is sufficient for an acre.

For winter use store in a cool cellar and cover with sand or silo them in the field by corering with earth, then a layer of straw, then more earth of sufficient depth to keep from freezing. When first siloed leave a small open space on the top covered with straw until cold weather, to prevent heating. When cold, freezing weather comes cover this.

White Egg. Belongs to the class of quick-growing fall turnips, and for this purpose should be sown August 10 th, in this latitude: a farorite with market growers for winter and early spring sales. Its shape is nearly that of an egg; very fine sort. Price-5c per oz.; 10c per $1 / 1$ lb.; $45 \mathrm{c}$ per $1 \mathrm{lb}$; $35 \mathrm{c}$ par lb. in 10-lb. lots and up.

Purple Top Strap Leared. The most widely cultivated and best - known variety, Used largely for sowing broadcast among corn and potatoes. It is round and flat, white on the bottom and a redish purple abore the ground, and a very quick grower. It is a fine variety, either for the table or for stocls feeding. Price-5c per oz.; 15̃e per $1 / 1$ lb.; $40 \mathrm{c}$ per $1 \mathrm{lb}$.; $35 \mathrm{c}$ per $1 \mathrm{~b}$. in $10-1 \mathrm{~b}$. lots and up.

Early White Flat Dutch. An excellent garden variety; the best for spring sowing. Price-5e per oz.; $15 \mathrm{c}$ per $1 / 1 \mathrm{lb}$.; $40 \mathrm{c}$ per $1 \mathrm{~b}$.; $35 \mathrm{c}$ per $\mathrm{lb}$. in $10-$ lb. lots and up.

Extra Early Purple Top Mrilan. This is the earliest turnip in cultivation and a splendid variety; bulb white and flat, of medium size, with a bright purple top; one of the sweetest and finest flavored of summer sorts. Price-5e per pkt.; 10c per oz.; 25c per $1 / 1 \mathrm{lb}$.; $90 \mathrm{c}$ per $1 \mathrm{~b}$.; $80 \mathrm{c}$ per lb. in $10-1 b$. lots and up.

Early White Milan. One of the earliest turnips, possessing all of the good qualities of the Early Purple Top Milan. It is very smooth and entirely white. Its excellent qualities and fine appearance make it a valuable crop to srow, and it is ready for market a week earlier than any other white variety; will produce a heavy crop. It will be one of the best for market. Price -5e per pkt.; 10c per oz.; 30c per 1/4 lb.; $\$ 1.00$ per lb.; $90 \mathrm{c}$ per $\mathrm{lb}$, in 10-lb. lots and up.

\section{PURPLE TOP WHITE GLOBE.}

This excellent table variety is globular in shape, of good size and very attractive appearance. The roots are large, purple or dark red above ground, white below. The flesh is white, fine grained and tender. The roots when in best condition for the table are about 3 inches in diameter, but can be grown much larger for stock feeding. This sort keeps well for so early a variety and is one of the best for market use. Sometimes known as Red Top White Globe.

Price-5e per oz.; $15 \mathrm{c}$ per $1 / 4$ lb.; $45 \mathrm{c}$ per lb.; 35c per lb. in 10-lb. lots and up.

Add $8 \mathrm{c}$ per pound if by mail. 


\section{FLOWER SEEDS}

\section{ALYSSUM,}

SWEET.

Little Gem. A favorite little annual because of its fragrance and $\mathrm{a} b \mathrm{und} \mathrm{n} \mathrm{c} \mathrm{e}^{\mathrm{of}}$ bloom. Grows only six inches high, six inches high, yet one plant wil $\begin{array}{ll}\text { cover a space } & \mathbf{1 2} \\ \text { to } 20 & \text { inches in }\end{array}$ diameter and be a mass of the purest white from purest white from early summer until frost. One of

for beds, borders and rockwork. Price-5e per pkt.

\section{ASTER}

\section{THE QUEEN OF ALTUMN ANNUALS.}

Semple's Branching Mixed. Plants are of branching habit, vigorous growth and profuse in bloom. The flowers are borne erect on very long stiff stems, are of extraordinary size, being 4 inches or more in diameter, and very graceful. The twisted ind curled petals give them the appearance of large Japanese Chrysanthemums. A prime favorite for cut flowers. Blooms a little later than some varieties, thereby escaping the ravages of the Aster beetle. Price-10c per pkt.

\section{ANTIRRHIUM.- Snapdragon.}

Giant Flowered Mixed. A most beautiful new sort, having all the finest colors and markings and a perpetual bloomer. The flowers are of immense size and produced in long spikes 1 to 2 feet in length. They succeed best in a rather light soil in a sunny position, and although perennials, are best treated as annuals. Price-10c per pkt.

\section{CANDYTUFT.}

New Empress. Among the most highly prized of summer annuals, considered indispensable for cutting. The heads of bloom are quite large and pure white. Perfectly hardy, grows easily and blooms throughout the season. Looks best in beds and masses. Sow outside where it is to bloom. Height 1 foot. Price-10c per pkt.

\section{BALSAMS. -Lady Slipper.}

Double Camelia-Flowered Mixed. An excellent strain. The flowers are large, of fine form and as double as a Camelia; colors varied and brilliant. For the finest double blossoms, transplant two or three times. Height 2 feet. Price-5e per pkt.

\section{CANARY BIRD VINE.}

A member of the Nasturtium family. A beautiful rapid-growing, annual climber, the charming little canary colored blossoms bearing a fancied resemblance to $a^{\circ}$ bird with its wings half expanded. Price-5e per pkt.

\section{CANNA.}

Crozy's Dwarf Mixed. Produces plants of dwarf, luxuriant growth with inmense gladiolus-like flowers of the most brilliant colors. They will bloom freely the first year from seed if started about the middle of April. Before planting soak the seed in hot water twenty-four hours. When plants are up to the second leaf, transplant singly into pots. Set out in the garden after all danger of frost is past. The roots can be kept in the cellar over winter. Price-10c per pkt.

\section{CENTAUREA.-Sweet Sultan.}

Centaurea Imperialis Mixed. This is without doubt the most beautiful of all the Sweet Sultans, and unsurpassed for early summer flowers. The flowers are large, very sweet scented and borne in great abundance on long, graceful stems, rendering them valuable for cutting. Price-10c per pkt.

\section{CYPRESS VINE.-Ipomoea Quamoclit.}

Finest Mixed. The delicate fern-like foliage and masses of white and scarlet star-shaped flowers makes this one of the most beautiful climbers imaginable. Trained to trellises or allowed to run up strings or poles, it is unsurpassed for grace and beauty. Sow in the open ground only after it is thoroughly warm. The seed starts more readily if soaked in warm water two hours before sowing. Grows about 6 feet high. Price-10c per pkt. 


\section{贾 FLOWER SEED----Continued

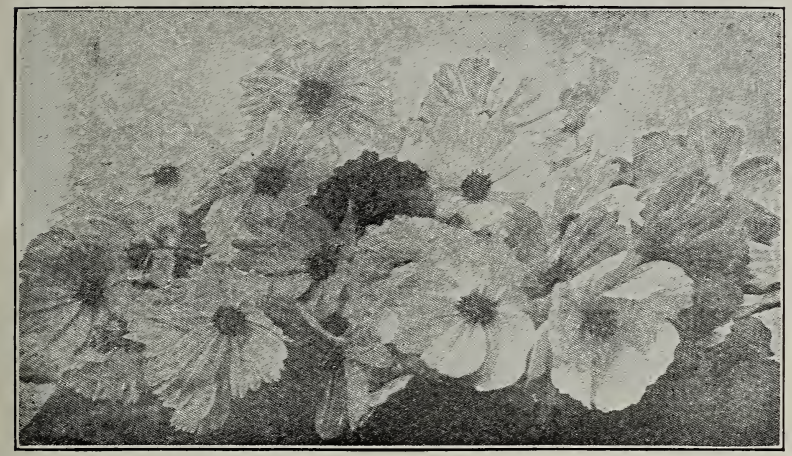

\section{COSMOS}

Early Flowering Mixed. A favorite fall flower. Tuis early flowering strain may be had in bloom from July to November. Plants are such strong, vigorous growers and so free with their favors, they can scarcely be spared from any garden. Grown in rows or massed it makes a fine display; splendid for bouquets. Height 4 to 6 feet. Price-5e per pkt.

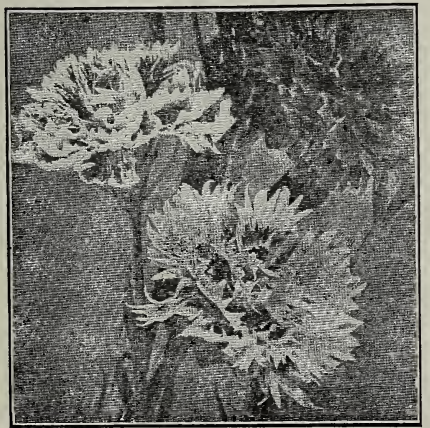

\section{DIANTHUS.}

Double Mixed. Few flowers can equal these in beauty and profusion of bloom. For garden decoration they are one of the $\mathrm{most}$ satisfactory annuals, and as the stems are lo ng, are equally good for cutting. The combination of colors is almost endless. Price-5c per pkt.

\section{DAHLIA.}

Double Cactus Mixed. A distinct and elegant variety, the most popular at the present time. Unequalled for its rich and varied colors and perfection of bloom. Dahlias are easily grown from seed and bloom the first season. Seed sown in the house in March and April will produce flowering plants as soon as those grown from tubers, and no two plants will be alike in flower. Price-10c per pkt.

\section{DAISY}

Shasta. One of Luther Burbank's hybrids, the result of a cross between the common field daisy and a European sort. It is a hardy perennial, bearing large, graceful flowers of the purest whiteness, averaging about 4 inches in diameter. The stems are 12 to 18 inches long. The flowers remain fresh for two weeks or more after cutting. Price-10c per pkt. 


\section{ESCHSCHOLTZIA \\ California Poppy}

Glory of the West. Summer flowering annuals of low, spreading growth, delicate foliage and golden y e $110 \mathrm{w}$ flowers. Splendid for bedding. Very showy and f re e flowering. As the plants do not bear transplanting, so w where they are wanted to bloom and thin to 6 inches a p a t. Price - 5c per pkt.

GAILLARDI. Blanket Flower.

Fine Mixed. Beautiful annuals for the flower garden, producing showy plants 1 to 2 feet high to 2 feet high well everywhere. Very effectively grown in masses. Excellent for cutting Price-5̃c per plit.

\section{Geranium}

Zonale Mixed. An excellent mixture of the largest and finest varieties. Geraniums are very interesting plants to raise from seed, as there is always a chance of securing something new and desirable; in fact, propagation by seed is the only way to obtain new varieties. To get into bloom the first summer, sow seeds quite early in house and transplant as soon as large enough, giving more room. Set out in the garden when the weather will permit. Price-10e per pkt.

\section{Larkspur}

Emperor, Mixed. A well-known annual of great beauty. As they are not easily transplanted, sow the seed where the plants are wanted to bloom and thin out so they will stand at least 10 inches apart. Height 2 feet. Price-5e per pkt.

\section{Lobelia}

Finest Mixed. Charming little plants of low, compact growth, especially prized for the edgings of beds and borders. Plants grow 4 to 6 inches high and are covered with small star-like flowers of a deep rich blue and blue marked with white. Sow outdoors where the plants are to grow. Price-5e per pkt.

\section{Mignonette}

Giant Machet. The best of all Mignonettes. The spikes are thick and long, deeply tinged with red on creamy white and olive. Deliciously fragrant. A plentiful supply of this popular flower can be had by making sowings in April and again in July. Price-10c per pkt.

\section{Marvel of Peru---Mirabilis}

Four O'Clocks, Mixed. Pretty, old-fashioned annuals, thriving in any common garden soil and under almost any treatment. The flowers are funnel shaped, white, red, yellow and striped, very fragrant, and have the odd habit of opening at 4 o'clock in the afternoon, hence their name. Price-5c per pkt.

\section{Nasturtium}

Finest Dwarf Mixed. The improved dwarf varieties are among the most popular flowers for bedding, massing, etc., owing to their compact growth, richness of color and profusion of bloom. When planting, scatter the seeds thinly in rows or beds and cover about one and one-half inches deep, pressing the soil down firmly. After they are well up, thin to not less than 4 inches apart so the plants will have plenty of room in which to grow. Keep the flowers picked so no seed pods can form and you will have continuous bloom until frost. Price-5e per pkt.; 10c per oz. 


\section{FLOWER SEED----Continued}

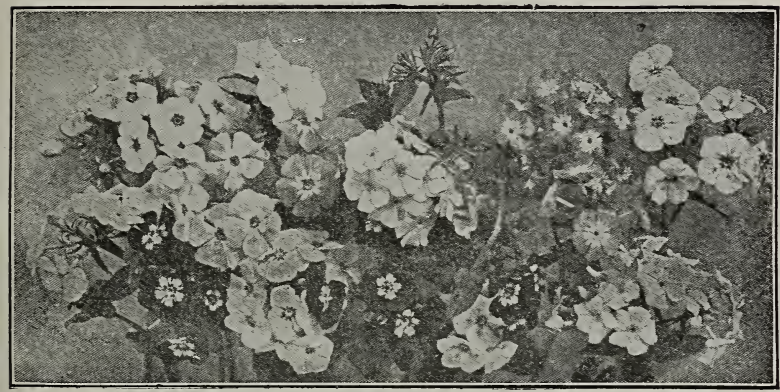

PHIOX.

Brummondii Grandiflora. Flowers nearly twice as large as the ordinary Phlox Drummondii, while the colors are richer and brighter. For beds, borders and massing it is unsurpassed. The colors range from purest white to deepest crimson. Sown outside they bloom very soon after planting and until frost. For early bloom, seed may be sown inside and transplanted. Height 1 to $11 /$ feet. Price-5e per pkt.

\section{POTTULACCA.-Rose Moss.}

Doubls Mixed. There are scarcely any flowers in cultivation which make such a dazzling display of beauty as a bed of many-hued portulaccas. Blooms from July until frost. Very desirable for beds, borders, rock work and ribbon beds and especially adapted for sunny situations and the light sandy soils. Sow in the garden as soon as it becomes warm and after the plants appear, withhold water. Stands any amount of hot, dry weather and can be easily transplanted when in full bloom. Price10 c per pkt.

\section{PANSY.}

Giant Trimardeau Mixed. The largest flowering of all pansies. To succeed with pansies, only the best seed should be sown. Have the bed where it will not receive the full heat of the sun; the east and north side of the house is generally a good location. Seed sown in the house or hot bed between January and April or in the open ground as soon as the soll can be worked in the spring will give flowers all summer and fall. For early spring blooming and for the largest and finest flowers, sow between July and September and protect during the winter. Price10c per pkt.

Paeony Flowered, Mixed. Large double showy flowers almost equal to Paeonies. Poppies are of quick growth and produce a wealth of the most gorgeous hlooms. Seed should be sown early where they are to bloom and covered lightly; thin to 6 inches apart. Do well in any good garden soil. Price-5c per pkt.

\section{PETUNTA.}

Giants of California. The largest flowering and richest colored variety in cultivation. Single flowers often measure over 5 inches in diameter, are exquisitely ruffled and fringed on the edges and beautifully veined in the deep throat. Their great variety of colors, markings and veinings distinguishes them from all others. Price-10c per pkt.

\section{SCABIOSA.}

Large Flowering Double Mixed. This is one of our best boquet flowers. The rich velvety blossoms are borne on long, graceful stems well above the foliage and after being cut keep in perfect condition for the greater part of a week. They are almost as durable as everlastings. The range of color is most remarkable, shading from pure white to rich pink, crimson to deep red, and from lilac to almost black. They are of the easiest culture. Make most effective beds and borders, and where many cut flowers are wanted are almost indispensable. Price-5c per pkt.

\section{VERBEXA.}

Mammoth Mixed. Single flowers of this Mammoth strain are of unusual size, while the clusters of bloom are magnificent and the range of color more vivid than in any other mixture. They are also deliciously fragrant. Although perennials, they bloom perfectly well the first season from seed and are more vigorous than if started from cuttings. For early spring bloom, sow quite early in boxes in the house and transplant to the open ground when it is warm. Seed sown in May will bloom in August. Price-5e per pkt.

\section{VTOLETS.}

Single Blue. The violet should not be wanting in any garden on account of its fragrance and early appearance. A single flower will perfume a whole room. Succeeds best in a shady, sheltered place. The violet is an emblem of faithfulness. Hardy perennial; 4 inches high. Price-5c per pkt. 


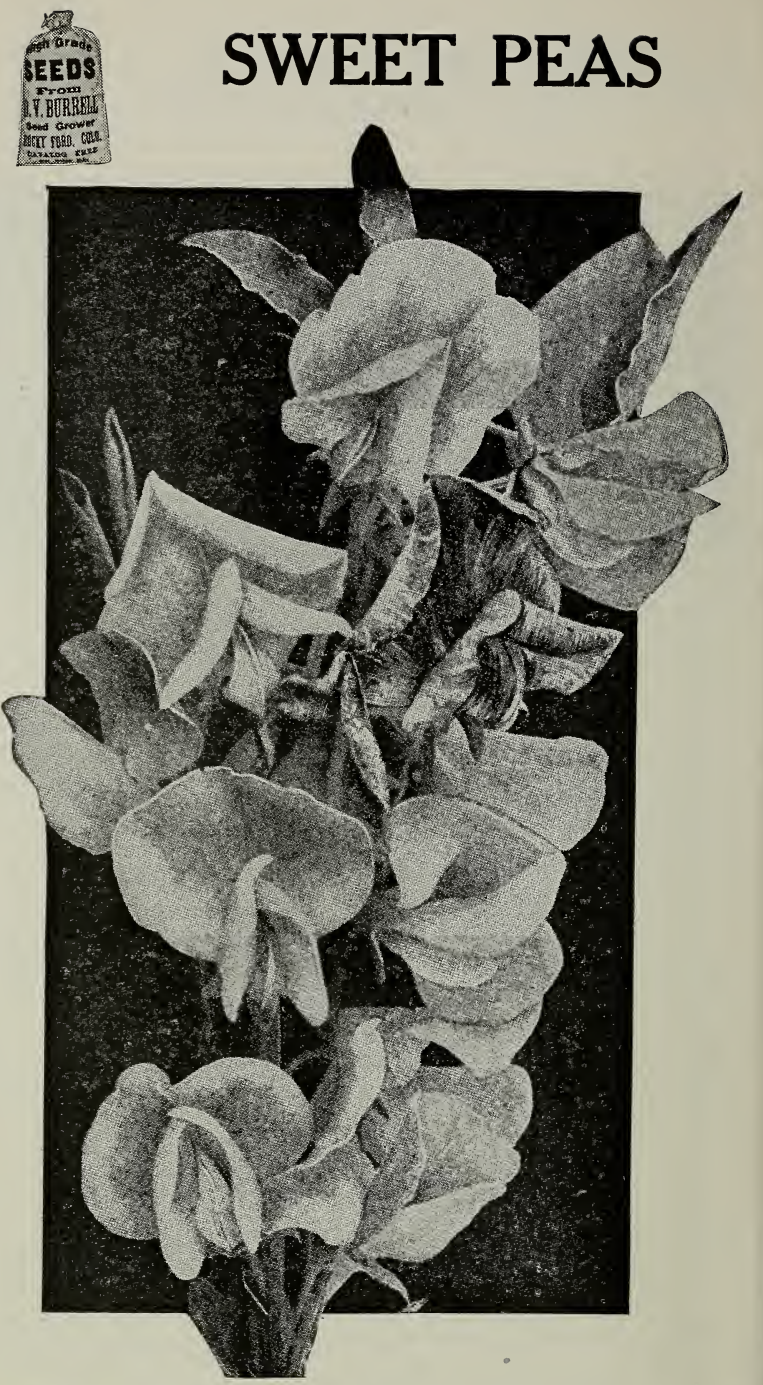

Burrell's Special Mixture, Tall. This mixture contains the finest varieties and gives almost every shade known in Sweet Peas. No flowers are more popular. Their profusion of bloom, delightful fragrance, showy and attractive appearance in the garden as well as when used for boquets and their easy culture makes them one of the most desirable of our hardy annuals. Sow as early as possible in the spring in mellow our hardy annuals. Sow as early as possible in the spring in mellow the plants grow. Provide support early. Ground bone and wood ashes are good fertilizers. Nitrate of soda will hasten blooming. Cut the flowers every day and there will be much more bloom. Price-5c per pkt.; 10c per oz.; 30c per 1/4 lb.; $\$ 1.00$ per 1 b.

Sweet Peas are a very short crop this year and these prices hold good only so long as my present supply lasts. Order early. 


\section{General List of Flower Seeds}

Abutilon. Large, bell-shaped flowers, richly veined; tender perennial. Finest varieties mixed. Price-5c per pkt.

Ageratum. Used largely for bedding and borders; mixed colors. Price-5c per pkt.

Alyssum. Little Gem. See page 74 . Amaranthus Tricolor. (Joseph's Coat.) Showy annual foliage plant; leaves red, yelluw and plant; Height 3 feet. Price-5c per pkt.

Anemone, (Wind Flower.) Beautiful spring flowering plants; many rich colors. Hardy perennial. Price-5c per pkt.

Antirrhinum. (Snapdragon.) Giant Flowering Mixed. See page 74

Aquilegia. (Columbine.) A hardy perennial. Single Mixed. Price5c per pkt.

Asperula Azurea Setosa. Light blue or lavender flower. Hardy annual. Height 9 inches. Price 一б́c per pkt.

Aster. Semple's Branching, Mixed. See page 74

Semple's Pure White. Price$10 \mathrm{c}$ per pkt.

Semple's Light Blue. Price-10c per pkt.

Semple's Shell Pink. Price-10c per pkt.

Asparagus Fern Sprengeri. Fine plant for pot culture or hanging baskets. Price-10c per pkt.

Bachelor's Button. A showy annual; great variety of colors. Price-5c per pkt.

Balloon Vine. (Love in a Puff.) Rapid growing annual climber; white flowers, followed by balloon-like seed pods. Price-5c

per pkt. See page 74

Calliopsis. Showy garden annual; golden yellow flowers; choicest mixture. Price-5e per plkt.

Canary Bird Vine. See page 74

Candytuft. See page 74 .

Canna Cozy's Dwarf. See page 74

Carnation. Choice Double Mixed. Produces many double flowers of all shades and colors. Price 10c per pkt.

Centaurea. Imperialis Mixed. See page 74.

Celosia Cristata. (Cockscomb.) Tall sorts, mixed. Price-5c per pkt.

Clematis. Paniculata. One of the finest hardy climbers Fragrant white flowers. Price-5c per pkt.

Coix Lachryma. (Job's Tear's.) Curious ornamental grass from East India with broad corn-like leaves, and seeds of a light slate color wonderfully lustrous. Valuable for winter bouquets. Price-5c per pkt.

Convolvulous. (Morning Glory.) Major. All colors mixed. Price -5c per pkt.

Cosmos. Early Flowering, Mixed. See page 75 .

Chrysanthemum. Annual Varieties Mixed. Price-5e ner pkt.

Perennial Varieties Mixed. Price10c per pkt.

Cuphea. (Cigar, or Firecracker Plant.) A pretty bedding plant. Flowers resemble a lighted cigar. Mixed. Price-5e per pkt.

Cypress Vine. See page 74
Dahlia. Double Cactus Mixed. See page 75 .

Daisy. Shasta. See page 75 . Bellis, or Double Daisy. Perennials, will bloom the same season if sown early. Price-10c per pkt.

Dianthus. Double Mixed. See page 75.

Snow Queen. Beautiful snow white variety of pinks. Price-10c per pkt.

Digitalis. (Foxglove.) Flowers borne in tall spikes, bell or thimble shaped. All colors. Price-5c per pkt.

Dolichos. (Hyacinth Bean.) Desirable climbing plant Mixed colors. Price-5e per pkt.

Eschscholtzia. (California Poppies.) See page 76 .

Fuchsia. Double, Finest Mixed. Easily grown from seed. Price25c per pkt.

Gaillardia. See page 76 .

Geranium. Zonale Mixed. See page 76 .

Gilia. Mixed colors. Hardy annual. Among the earliest to flower and will keep long in water. Flowers grow in clusters. Price-5c per pkt.

Gypsophila. (Baby's Breath, or Angel's Breath.) Filegant. Charming for mixing with boquets. Star-shaped white flowers. Price-5e per pkt.

Heliotrope. Fine Mixed. Very fragrant, excellent for bedding or indoor culture. Price-5e per pkt.

Hollyhock. Double Mixed, Best. The flowers are as double as a rose and of many shades of colnr. Once started they keep coming year after year. Price10c per pkt.

Double Mixed, Good. Price-5e per pkt.

Ipomoea. (Moon Flowers, Brazilian Morning Glories.) New Hybrid climbers of very rapid growth, with many beautiful and varied flowers. Price-10c per pkt.

Lantana. Finest Mixed. Tender per $€$ nnial. Excellent for hedding or. pot culture. Price-5c per pkt.

Larkspur. Emperor Mixed. See page 76 .

Lobelia. Finest Mixed. See page 76.

Marigold. African Mixed. Of easy cultivation, producing an elegant display of perfectly double orange, yellow and brown flowers. Height 3 feet. Price-5c per pkt.

Marvel of Peru. Four O'Clocks Mixed. See nage 76 .

Matricaria. (Feverfew.) Capensis, double white. Will bloom first season from seed. Perennial. Price-5c per pkt.

Mignonette. Fiant Machet. See page 76.

Irosotis. (Forget-Me-Not.) Palustris. Neat and beautiful little plants, with pretty star-like flowplants, succeed best in a moist. ers. Succeed bloom first year if sown early. Price-5c per pkt. 


\section{Flower Seeds---Continued}

Nasturtium, Finest Dwarf Mixed. See page 76 .

Tall Varieties Mixed. Suitable for trellis. Price-5e per pkt.; 10c per oz.

Nigella. (Love in a Mist.) Small blue flowers, finely cut foliage. Hardy annual. Price-5e per pkt.

Oxalis. Mixed. Very attractive plants, with richly colored flowers, suitable for rock work and rustic baskets. Half-hardy perennial. Height 6 inches. Price -10c per pkt.

Pansy, Giant Trimardeau Mixed. See page 77 .

Good llixed, Price-5e per pkt. Giant Golden Queen. Price-10c per pkt.

Giant Royal Purple. Price-10c per pkt.

Giant Violet Blue. Price-10c per pkt.

Petunia. Giants of California. See page 77 .

Phlox. Drummondii Grandiflora. See page 77.

Poppy. Paeony Flowered. See page

Double Carnation F low ered Mixed. Price-5e per pkt.

Portulacca. Double Mixed. See page 77 .

Single Mixed. Price-5c per pkt.

Primula Veris. (Cowslip.) The well - known English Cowslip, flowering early in spring. Price -5c per pkt.

Pyrethrum. (G o ld en Feather.) Very useful and universally admired, ornamental foliage bedding plants. Golden-yellow foliage and white flowers. Price5e per pkt.

Ricinus. (Castor Oil Plant.) Stately, strong growing plant with very ornamental foliage. Annuals of very quick growth. Price-5c per pkt.

Rhodanthe. Mixed. One of the best everlasting flowers and a charming annual. Price-5e per pkt.

Salpiglossis. Mixed Varieties. (Velvet Flower or Pointed Tube Tongue.) Showy bedding or border plants, with richly colored erect funnel-shaped flowers. Price-5e per pkt.

Salvia. (Scarlet Sage.) Price-10c per pkt.

Scabiosa. (Mourning Bride.) See page 77

Schizanthus. (Butterfly Flower.) Mixed colors. Excellent freeflowing plant for garden or greenhouse, bearing peculiarly shaped and oddly marked flowers. Hardy annual. Price-5e per pkt.

Silene. (Catchfly.) Mixed colors. Very pretty for low beds or edgings. Flowers white, pink and red. Annual. Price-5e per plst.

Sensitive Plant. Leaves close if touched. Price-5c per pkt.

Smilax. Charming tender perennial climber for greenhouse or window gardens. Very graceful. Excellent for decoration. Price -10c per pkt.
Stocks. (Gillyflower.) Good mixed. Unsurpassed in brilliancy of color and general effect. Fine for bedding, borders, massing and pot culture. Price-10c per pkt.

Stokesia Cyanea. (Cornflower Aster.) Beautiful blue flowers borne freely until frost. Price10e per pkt.

Sweet Peas. Burrell's Special Mixture. See page 78 .

Eckford's Mixed. This mixture contains all of the famous Eckford varieties in an excellent mixture. Price-5e per pkt.; 10c per oz.; 30c per $1 / 4$ lb.; $\$ 1.00$ per 1 b.

Bush Sweet Peas. A splendid mixture, entirely distinct. The plants are erect, 15 to 18 inches in height, branching freely, requiring no support. The flowers are of fine form and beautiful coloring, but not quite so large as the tall Sweet Peas. Price-5c per pkt.; 10c per oz.; 30e per $1 / 4$ lb.; $\$ 1.00$ per $1 b$.

Cupid Sweet Peas, Mixed. Price -5c per pkt.; 10c per oz.; 30c per $1 / 4 \mathrm{lb}$.; $\$ 1.00$ per $1 \mathrm{~b}$.

Prỉces of the following named Sweet Peas: 5e per pkt.; 10c per oz.; 30c per $1 / 4 \quad$ lb.; $\$ 1.00$ per $1 \mathrm{~b}$.

Blanche Burpee. Large, pure white of graceful and open form.

Mrs. Eckford. A beautiful shade of light primrose yellow.

Blushing Beauty. Light pink, attractive.

Lovely. A most beautiful shade of shell pink.

California. Very light pink.

Irs. Dugdale. Light carmine rose; very large.

Her Majesty. Large, fi n e l y hooded flowers of beautiful soft rose, deep and glowing.

Salopian. A grand scarlet.

Venus. A lovely shade of salmon buff.

Blanche Ferry. Standards rosepink; wings white, tinted rose.

Black Knight. Deep maroon, veined black.

Aurora. Creamy white, striped orange salmon.

Admiration. A delicate shade of rosy lavender.

Captivation. Claret magenta; wings heliotrope; a distinct shade.

Countess Cadogan. Color effect is that of a bright blue.

Sweet William. Double Mixed. Hardy perennial. Flowers are produced in very large heads in many brilliant and rich colors. Price-5e per pkt.; Single Mixed, 5c per pkt.

Thunbergia. (Climbing Black-eyed Susan.) Mixed. A trailing or climbing plant with flowers of various shades of yellow and white, having a dark center, or eye. Price-10e per pkt.

Verbena, Mammoth Mixed. See page 77 .

Violets. Single Blue. See page 77 .

Zinna. (Giant Mammoth Mixed.) Price-5c per pkt. 


\section{Here Are a Few of}

My Customers

Space will not permit me to give more. They are among the leading growers of the United States. Their products bring many millions of dollars each year. They have confidence in my seeds. During the past fifteen years some of these parties have ordered many times the amounts given. These are one year's orders from them. I give these few to show you that you can afford to send me your big orders or your home garden orders.

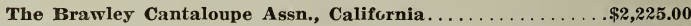
English \& Oliver, North Carolina $\ldots \ldots \ldots \ldots \ldots \ldots \ldots \ldots \ldots$ 986.45

R. I. Newsome, Georgia $\ldots \ldots \ldots \ldots \ldots \ldots \ldots \ldots \ldots \ldots \ldots \ldots \ldots .360 .00$

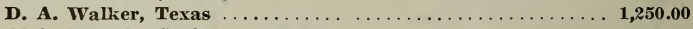
Alvin F. \& T. G. Assn., Texas $\ldots \ldots \ldots \ldots \ldots \ldots \ldots \ldots \ldots \ldots 645.00$

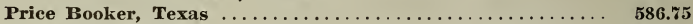

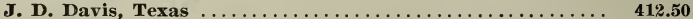

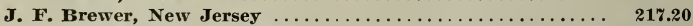

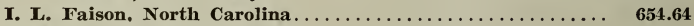

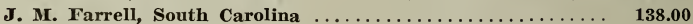

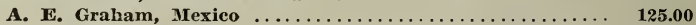

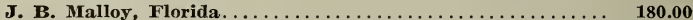

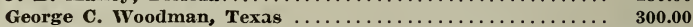

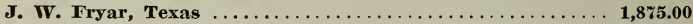

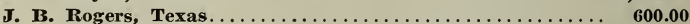

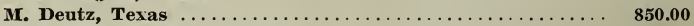

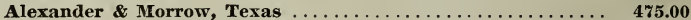

Cross S. Farming Co., Texas $\ldots \ldots \ldots \ldots \ldots \ldots \ldots \ldots \ldots \ldots \ldots, \mathbf{3 1 3 . 1 0}$

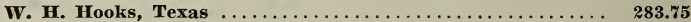

Mrs. Edwarts Calahan Dodd, Texas ...................

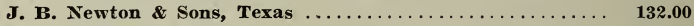

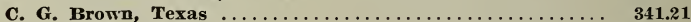

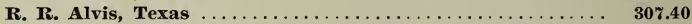

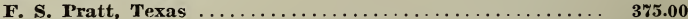

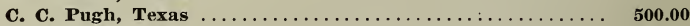

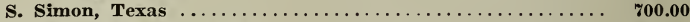

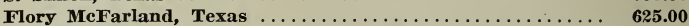

Santo Domingo L. \& I. Company, Texas............ 750.00

I could give thousands more who have sent in fine orders. My seeds have an excellent reputation.

I want your orders. Awaiting your favors, I am,

$$
\text { Yours truly, }
$$

D. V. BURRELL,

Seed Grower, Rocky Ford, Colo. 